\title{
Do women contribute more effort than men to a real public good? ${ }^{*}$
}

\author{
Ingela Alger ${ }^{\dagger}$ \\ Laura Juarez $\ddagger$ \\ Miriam Juarez-Torres ${ }^{\S}$ \\ Josepa Miquel-Florensa
}

January 28, 2020

\begin{abstract}
We present evidence from a lab-in-the-field experiment, conducted in eight small, rural villages in Mexico, in which subjects choose to exert real effort to fund real health centers in their own and other localities. We find that women are more willing than men to exert effort to fund the health center in another locality, relative to the one in their locality. This gender gap is mostly due to women who have some trust in the way the government spends taxes, and to women who benefit from a government program that targets women and fosters health care use. Our results also suggest that women might be aware of their higher willingness to exert effort for a public good that does not benefit them directly, compared to men, because they seem to reduce their individual effort the more female their environment is.
\end{abstract}

Keywords: public goods, gender, lab-in-the-field experiment, real effort, in- vs out-group transfers

JEL codes: H41, C91, O12

\section{INTRODUCTION}

Public goods such as education, health services, and infrastructure are key determinants of economic development. A society's ability to provide such public goods in turn depends on its ability to raise funds through taxes, and this appears to be a challenge in developing countries (Besley and Persson, 2014). While in the traditional economics approach tax compliance is motivated solely by the threat of punishment in case of detected non-compliance, the existence of intrinsically motivated taxpayers could improve compliance without necessarily increasing tax enforcement, thereby reducing the cost of raising funds (Erard and Feinstein, 1994).

*We thank the Agence Nationale de la Recherche for funding this research through a grant awarded to Ingela Alger (Chaire d'Excellence ANR-12-CHEX-0012-01). Ingela Alger further acknowledges funding from the European Research Council (ERC) under the European Union's Horizon 2020 research and innovation programme (grant agreement No 789111 - ERC EvolvingEconomics). Ingela Alger and Josepa Miquel-Florensa also acknowledge IAST funding from the French National Research Agency (ANR) under grant ANR-17-EURE-0010 (Investissements d'Avenir program), as well as the generous hosting by Banco de México. Finally, this paper would not have seen the light of day without the outstanding research assistance, both in the field and in the office, provided by Mariana Garcia and Ildrim Valley. Part of this research was conducted while Laura Juarez was a researcher at Banco de México. The views expressed in this article are solely those of the authors and do not necessarily reflect those of Banco de Mexico.

$\dagger^{\dagger}$ Toulouse School of Economics, CNRS, University of Toulouse Capitole, and Institute for Advanced Study in Toulouse, France. ingela.alger@tse-fr.eu

${ }^{\ddagger}$ El Colegio de México. laura.juarez@colmex.mx

§Banco de México. mjuarez@banxico.org.mx

ฯ Toulouse School of Economics, University of Toulouse Capitole, Toulouse, France. pepita.miquel@tse-fr.eu 
Empirical studies support the hypothesis that some individuals are more intrinsically motivated than others to pay taxes, by showing that there is heterogeneity in tax compliance behaviors (Slemrod, 2007, Mohdali et al., 2014, Mascagni, 2018). In this paper, we test whether women are more inclined than men to contribute to a real public good from which they may not benefit directly. If confirmed, such a difference would imply that policies that promote female labor market participation might enhance tax revenues per dollar earned in the population. Our work is motivated by the experimental literature on gender differences in economic experiments. ${ }^{1}$

To measure the subjects' real effort contributions towards a real public good that they could not benefit from themselves, we conducted a lab-in-the-field experiment which builds on a recently developed design (Alger et al., 2019). Subjects were given the opportunity to complete levels in a simple but boring task: marking the outline of pre-printed squares with a pencil on a sheet of paper. Each level completed by a subject increased her probability of generating earnings above and beyond the initial endowment, and all extra earnings were allocated to a public good. We consider two types of public goods: in the Local Public Good (henceforth LPG) game, the extra earnings benefited the public health center of the subject's village; in the Non-Local Public Good (henceforth NLPG) game, the extra earnings benefited the health center of another village, which was matched to the subject's village before the experiment. The subject could benefit directly from the health center of her own village but not from the one in the matched village. Our analysis focuses on the difference in effort exerted in the NLPG and that exerted in the LPG. Arguably a gender gap in this effort difference is a clean measure of the discrepancy between men's and women's willingness to contribute real effort to a real public good that they cannot benefit from themselves, since it controls for the efforts they exert towards a public good from which they do benefit.

Compared to the classic public good games presented in the literature, our experimental design presents several advantages. First, in our experiment the amount of the monetary contribution to the public good is imposed by us. Hence, the effort choice is isolated from the transfer choice, whereas in other experiments both are simultaneous. Second, in the classical public goods experiment, a contribution made by a subject not only increases the benefit for the public good, it also reduces the subject's own payoff. By contrast, in our experiment the effort chosen by a subject in a public good task has no impact on the subject's own payoff, only on the resources allocated to the public good, thus eliminating income effects. Third, as mentioned, we use a real public good, the village health center, from which the subject may or may not benefit directly, depending on the game (LPG vs NLPG). Fourth, in both public good games a perfectly selfish subject had no incentive to exert effort because a $100 \%$ of the extra earnings were "taxed away"; hence, any effort exerted by a subject could be interpreted as her willingness to exert real effort towards the benefit of the public good at hand. Finally, the experimental design allows us to abstract from social norms in tax compliance (Perez-Truglia and Troiano, 2016), because we ensured that individual decisions were unobserved by other participants. Arguably, then, we are measuring subjects' intrinsic willingness to contribute real effort towards a real public good.

A second strength of our study is that it samples a population with low previous exposure to formal institutions. This minimizes the risk that observed gender differences would be due to differential exposure to formal taxes. Specifically, we conducted the experiment in rural villages, inhabited mostly by poor farmers, in the Mexican state of Yucatan. ${ }^{2}$ We had a total of 244 participants in eight of these villages. As mentioned, each village where a session was conducted was matched with another village that was not part of the experiment. The proceeds from the LPG game went to the health center in the experimental village, whereas those from the NLPG game went to the health center of the matched village. In each village, half of the participants were randomly allocated to a Donor treatment, and the other half were allocated to a Recipient treatment. In the

\footnotetext{
${ }^{1}$ Please refer to the surveys by Croson and Gneezy (2009), and Niederle (2017).

${ }^{2}$ There is a large literature on behaviors and network structures in small villages in Mexico (Angelucci et al., 2009, 2010).
} 
Donor treatment, any extra earnings generated by the subject were given to the public good; in the Recipient treatment, failure to generate extra earnings reduced the amount of resources given to the public good, because the subject was compensated for this lack of extra earnings from those resources. In consequence, this design further allows us to examine whether the gender differences in the willingness to exert effort for a public good also vary by whether the subject generates additional resources for the public good or reduces them. ${ }^{3}$

Our empirical analysis consists in estimating the effort difference between the game in which the public good is the health center in the matched village (NLPG game) and the game in which it is the health center in the subject's village (LPG game), and testing whether this effort difference varies significantly with gender. We also examine whether this gender gap in effort difference, if present, varies with the roles of Donor and Recipient. To control for any individual characteristics that might affect effort, and that remained constant throughout the experimental session, we include player fixed effects in all our estimations.

We find a a positive and statistically significant gender gap in effort difference for Donors. On average, female Donors make about $7 \%$ more effort than male Donors in the NLPG, relative to the LPG game. Thus, female Donors are more willing than their male counterparts to exert effort when it benefits the health center of another locality, compared to when it benefits the health center of their own locality. For Recipients, this gender gap in relative effort is close to zero, and not statistically significant. The overall effort difference between those two games is not statistically significant when pooling men and women in both roles in the estimation. Also, we find no significant effort difference by role alone. In sum, we find a positive and significant difference in relative effort only when looking at the interaction of role and gender. These findings are robust to controlling for the order of games in the experimental session, and to the use of different effort measures.

To provide some evidence on the factors that could drive this positive gender gap in effort difference between the two public good games, we examine whether it varies with informal giving and receiving patterns, measures of community involvement and trust, proxies of the strength of the participant's network in her own and in the matched village, and other sociodemographic characteristics at the individual and the locality level. Many of these variables are indirect measures of pro-social inclinations, strength of local and non-local networks, personal beliefs and participation in government programs. We find that the positive gender gap in relative effort for Donors does not vary with most of these variables, except for the trust the participant has in the government, and her participation in government programs. Specifically, our findings suggest that most of this gender gap in effort is due to the behavior of women who have at least some trust in the way the government spends taxes. It also seems to be due to women who participate in the Oportunidades program, which pays a cash transfer to poor, rural women, conditional on complying with scheduled health checks for children and adults in their households. ${ }^{4}$ Thus, Oportunidades beneficiaries, women who likely use health services relatively often, are those who are more willing to exert effort than men for the clinic at the matched locality, relative to that in their own locality. Regarding other government programs, the positive effort gender gap is larger for Donors who do not participate in the Procampo program, ${ }^{5}$ which suggests that it is larger for women from landless households, who are not eligible; it is also larger for those who participate in fewer government programs overall. For Recipients, the results from this analysis are mostly similar to our main ones.

Finally, we examine whether the willingness of a given participant to exert effort in the NLPG versus LPG game is affected by the gender composition of her fellow session participants. This could arise if the player

\footnotetext{
${ }^{3}$ Our findings may thus be relevant for the literature on the extensive vs. the intensive effect of taxes on effort. There is an extensive literature on undesirable effects of taxes and unemployment insurance on labor choices (see for example Kugler and Kugler (2009))

${ }^{4}$ The literature evaluating different aspects of this program is extensive. For recent surveys on the long-term effects of this program, see Millán et al. (2019), and on impact on education see Gertler et al. (2006)

${ }^{5} \mathrm{http}: / /$ www.agricultura.gob.mx/que-hacemos/procampo
} 
expects other participants to exert more or less effort, depending on their gender. We find that the positive gender gap in relative effort between those two games for Donors decreases with the share of female participants in the experimental session, which suggests that women might be aware of their higher willingness to exert effort for a public good that does not benefit them directly, compared to men, and so they reduce their individual effort the more female their environment is.

If externally valid, our findings suggest that in rural Yucatan, women are, on average, more willing than men to contribute to public goods that do not benefit them directly. Our additional results showing that most of this gender gap is due to women who trust the way in which the government spends taxes, and to women who participate in a program that targets them and fosters health care, lend credibility to this conclusion. However, two caveats are in order: one general and one specific to the population we studied (Levitt and List, 2007). First, in our experiment subjects undertake effort for a short time, while in reality productive efforts take place over extended periods. Second, the population we sampled is exposed to the village-based communal land system known as ejido, which involves mostly men. This may have a positive impact on men's pro-sociality towards their own village. ${ }^{6}$

Our study contributes to an already large body of experimental work that examines behavioral differences between women and men. In particular, it contributes to the literature on contributions made by subjects in public goods games. The evidence from laboratory experiments is $\operatorname{mixed}^{7}$, and on the whole neither men nor women appear to consistently make larger contributions, although the distributions of contributions as well as the sensitivity to particular features of the experimental designs do differ (Niederle, 2017). While experiments conducted outside of controlled laboratory settings are rare, the data collected by way of a field experiment by DellaVigna et al. (2013) are also consistent with this. More generally, our study is in line with the growing interest in the potential effects that women's empowerment has on economic performance, both in developed (Bertrand, 2011, Adams and Funk, 2012), and in developing countries (Beaman et al., 2012, Field et al., 2016, Dupas and Robinson, 2013).

The experiment is described in the next section, and the following three sections report the results. A concluding section discusses possible future research questions that our study raises.

\section{THE EFFORT-AND-TRANSFER EXPERIMENT}

\section{A. Experimental design and session structures}

Each subject played a series of four games, one of which was randomly drawn at the end of the experimental session to determine the payoffs. In each game the subject was presented with the same initial endowment and the same real effort task; the subject's only decision consisted in performing effort. The subject's effort level determined her probability of generating additional income. The task, as well as the randomization device used to determine whether additional income was generated, will be described in detail in the next subsection. Here we describe the games and the payoffs.

Among the four games, only three are relevant for the question we address, but we will describe all of them in turn for completeness. In the Autarky game, the subject's payoff was augmented with the additional income if this materialized, but otherwise (s)he simply got the endowment. In the two public goods games, whether or

\footnotetext{
${ }^{6}$ Relatedly, Carpenter and Seki (2011) find that exposure to teamwork had a positive impact on contributions in public goods games among fishermen.

${ }^{7}$ For example, in experiments conducted on students with standard linear public goods games, Brown-Kruse and Hummels (1993) find that women make lower contributions than men on average, while Nowell and Tinkler (1994) find the opposite.
} 
not the additional income materialized had a consequence on the amount of money given to a health center: the health center in the subject's village in the LPG game, and the health center in another village in the NLPG game. However, there was no consequence on the subject's own payoff. The fourth game, not used in this paper, will be described below. The experimental protocol and visual materials can be found in Appendix B.

The experiment was conducted in 8 villages. In each village the subject pool was divided randomly into two groups of equal size, usually around 20 participants, one of which was allocated to the Donor treatment, and the other to the Recipient treatment. These treatments differed in the way additional income affected the amount of money given to the health center in the two public good games. In the Donor treatment, when the additional income materialized, it was added to the total amount to be given to the health center, as though the individual had given this additional income to the health center. In the Recipient treatment, any subject who failed to generate additional income received the equivalent amount from the pot of money to be given to the health center, as though the individual had received this amount from the health center.

Figure 1 summarizes the payoff consequences of success (S) and failure (F) in the Autarky, LPG, and NLPG games. The first number in a cell is the initial endowment, an italicized number is the additional income generated if lucky, a bold number is a transfer, and $n$ is the total number of subjects in a given group of subjects.

Focusing first on the Donor treatment, each subject's endowment was 100 in each game, ${ }^{8}$ and the additional income generated in case of success was 75 . If a public good game was selected to calculate the payoffs, we would let $25 n$ be the baseline amount to be given to the health center at hand (the one in the village in the LPG game, and the one in another village in the NLPG game). Any additional income generated through the subjects' efforts was added to this amount. Hence, from any given subject's perspective, if $n_{s}$ other subjects succeeded at generating additional income, the effect of his or her success was to increase the total amount given to the health center from $25 n+75 n_{s}$ to $25 n+75 n_{s}+75$.

In the Recipient treatment, the additional income generated in case of success was also 75, but each subject's initial endowment in each game was 25. If a public good game was selected to calculate the payoffs, we would let $175 n$ be the baseline amount to be given to the health center at hand. Any subject who failed to generate additional income received 75 from this pot. Hence, from any given subject's perspective, if $n_{f}$ other subjects failed to generate additional income, the effect of his or her failure was to decrease the total amount given to the health center from $175 n-75 n_{f}$ to $175 n-75 n_{f}-75$.

In the fourth game (the One-to-One game), which we do not use in this paper, each active subject was matched anonymously and bilaterally with one passive individual. In any such match, the passive individual received the additional income generated by the active individual in the Donor treatment, and was inflicted a reduction in his or her payoff if the active individual failed to generate additional in the Recipient treatment. An individual was informed about the payoffs (s)he obtained from being such a passive individual in the One-to-One game only at the moment (s)he was paid in case this game was selected for payment.

The session structures are summarized at the bottom of Figure 1: an incentivized ability test was conducted both before and after the games; two alternative game orders were used, each being applied in four randomly chosen villages; at the very end of the session, subjects filled out a questionnaire with questions pertaining to standard individual characteristics and transfer behaviors in the past year. We also asked some postexperimental questions, which we do not use for the analysis in this paper because they were related to the One-to-One game.

\footnotetext{
${ }^{8}$ All the numbers are expressed in points, the experimental unit, worth MXN 0.50 each (when the experiment was conducted, the exchange rate was approximately MXN $13=$ USD 1). The overall average payoff turned out to be MXN 103.62 (it was MXN 103.07 across the Donor treatments, and MXN 104.18 across the Recipient treatments).
} 


\begin{tabular}{|c|c|c|c|c|}
\hline Game & State & $\begin{array}{l}\text { Payoff to } \\
\text { Subject }\end{array}$ & $\begin{array}{c}\text { Payoff to Passive } \\
\text { participant }\end{array}$ & $\begin{array}{c}\text { Payoff to Health } \\
\text { center }\end{array}$ \\
\hline \multirow{2}{*}{ Donor Autarky } & $\mathrm{s}$ & $100+75$ & & \\
\hline & $\mathrm{F}$ & 100 & & \\
\hline \multirow{2}{*}{ Donor One-to-One } & & $100+75-75$ & $25+75$ & \\
\hline & $\mathrm{F}$ & 100 & 25 & \\
\hline \multirow{2}{*}{$\begin{array}{l}\text { Donor Local } \\
\text { Public Good }\end{array}$} & $\mathrm{s}$ & $100+75-75$ & & $25 n+75 n_{s}+75$ \\
\hline & $\mathrm{F}$ & 100 & & $25 n+75 n_{s}$ \\
\hline \multirow{2}{*}{$\begin{array}{l}\text { Donor Non-Local } \\
\text { Public Good }\end{array}$} & $\mathrm{s}$ & $100+75-75$ & & $25 n+75 n_{s}+75$ \\
\hline & $\mathrm{F}$ & 100 & & $25 n+75 n_{5}$ \\
\hline \multirow{2}{*}{ Recipient Autarky } & & $25+75$ & & \\
\hline & $\mathrm{F}$ & 25 & & \\
\hline \multirow{2}{*}{ Recipient One-to-One } & & $25+75$ & 175 & \\
\hline & $\mathrm{F}$ & $25+75$ & $175-75$ & \\
\hline \multirow{2}{*}{$\begin{array}{l}\text { Recipient Local } \\
\text { Public Good }\end{array}$} & 5 & $25+75$ & & $175 n-75 n_{f}$ \\
\hline & $\mathrm{F}$ & $25+75$ & & $175 n-75 n_{f}-75$ \\
\hline \multirow{2}{*}{$\begin{array}{l}\text { Recipient Non-Local } \\
\text { Public Good }\end{array}$} & $\mathrm{s}$ & $25+75$ & & $175 n-75 n_{f}$ \\
\hline & $\mathrm{F}$ & $25+75$ & & $175 n-75 n_{f}-75$ \\
\hline \multicolumn{3}{|c|}{ Game order A } & \multicolumn{2}{|c|}{ Game order B } \\
\hline \multicolumn{5}{|c|}{ Incentivized ability test 1} \\
\hline \multicolumn{3}{|c|}{ Autarky } & \multicolumn{2}{|c|}{ Autarky } \\
\hline \multicolumn{3}{|c|}{ One-to-One } & \multicolumn{2}{|c|}{ Local Public } \\
\hline \multicolumn{3}{|c|}{ Local public } & \multicolumn{2}{|c|}{ One-to-One } \\
\hline \multicolumn{3}{|c|}{ Non-Local Public } & \multicolumn{2}{|c|}{ Non-Local Public } \\
\hline \multicolumn{5}{|c|}{ Incentivized ability test 2} \\
\hline \multicolumn{5}{|c|}{ Post-experimental questions } \\
\hline \multicolumn{5}{|c|}{ Questionnaire } \\
\hline
\end{tabular}

Figure 1: Payoff consequences in the four games, and the two game orders.

\section{B. The filling-in squares effort task}

Given our focus on effort choices, we propose a real effort instead of a "chosen effort" task (Bruggen and Strobel, 2007). Since the subject's own payoff is not affected by the effort, this has the advantage of avoiding income effects. The effort task consisted of using a pencil to mark the outline of pre-printed squares on a sheet of paper. ${ }^{9}$ The sheet had ten lines of empty squares, each line corresponding to one "level"; to make sure that there was an increasing marginal cost of effort, each level $\ell=1, \ldots, 10$ required $\ell$ squares to be marked. For each completed level, the subject increased the probability of generating additional income by $1 / 11$, the probability being zero if no level was completed. Once the game that would be used to calculate the payoffs had been picked, a traditional style bingo cage with balls numbered from one to ten plus a black ball was used for the

${ }^{9} \mathrm{~A}$ variety of real effort tasks have been used in the literature, such as solving anagrams (Charness and Villeval, 2009), stuffing envelopes (Carpenter et al., 2010), counting zeros (Abeler et al., 2011), moving sliders (Gill and Prowse, 2012), and threading nuts onto bolts (Alger et al., 2019). We chose a manual task that did not require the use of computers. 
draw. If the black ball was drawn, no additional income was generated for anyone. If a ball with a number was drawn, any subject who had completed a number of levels equal to or greater than the number on the ball drawn in the relevant game generated additional income, whereas those who had completed a smaller number did not. In each game, the subject had one minute for the task. Curtains ensured that subjects could not observe each other's effort choices or communicate. Furthermore, to minimize the experimental pressure to exert effort, each subject could at any time choose to look in a magazine that (s)he had picked among a large set of magazines when entering the room, and that (s)he knew that (s)he had to return when exiting.

Marking squares is a task that requires some ability. To measure each subject's ability, we let them take two incentivized ability tests, one at the beginning and one at the end of the experimental session. In each ability test the subject was awarded one point for each properly marked square in one minute. The first ability test gives us information on baseline ability in performing the task. The baseline ability distribution, as measured with this first test, does not differ significantly across treatments (Wilcoxon test, $\mathrm{p}=0.7666$ ) or across genders (Wilcoxon test, $\mathrm{p}=0.4340$ ). Furthermore, in our main specifications, we include individual fixed effects to control for baseline ability and for any other individual-specific factors that might affect effort and that remained constant throughout the session.

Given that the effort task is performed repeatedly, learning or fatigue may also arise in our experiment. This is a potential confounding variable that must be adequately controlled for. Learning as measured on the percentage increase between the last and the first ability tests does not differ significantly across treatments (Wilcoxon test, $\mathrm{p}=0.3411$ ) or between the order of the games played in the session (Wilcoxon test, $\mathrm{p}=0.8953$ ). We neither find differences on gender learning in each of the orders (Wilcoxon test, $\mathrm{p}=0.1592$ and $\mathrm{p}=0.1865$ for each of the orders). We discuss in detail in Appendix A several robustness tests performed to account for ordering and learning in our results.

\section{C. Procedures}

We recruited subjects by way of public announcements (loudspeaker announcements and written ads) supported by the village authorities, one day ahead of the session as well as on the same day. In each of the 8 villages, our goal was to obtain a total of 40 subjects, gender-balanced whenever possible. For this, we applied a "first come, first served" rule for men and women separately. At most one individual per household could participate. Indeed, although most of the localities were small (less than $700 \mathrm{inh}$.), the questionnaire data suggest that only a small share of the subjects were first-degree relatives (see Table A1). Table A2 further shows that participants in the Donor and the Recipient treatments do not differ significantly in their socioeconomic characteristics, collected in the post-experimental questionnaire. Upon arrival, each participant was asked to pick a card from an opaque bag; the card had a number, which we used to track the subject anonymously, and a symbol, which was used to assign the participant to the Donor or the Recipient treatment. Half of the subjects were then led to the lab field, while the other half were shown to another room, where they were served a snack while they waited for their turn to be led to the field lab. In the One-to-One games, each active subject was randomly and anonymously matched with one passive subject, so that each active and each passive subject was matched with exactly one individual.

The sessions were conducted in the village's school building, usually in the afternoon after the end of the agricultural labour day. The active and the passive subjects were led to two separate rooms. In each village we arranged the twenty tables and chairs in the lab room into four columns facing the experiment director, who was the same in all the sessions. No written instructions were provided; instead, the director conveyed the protocol orally because she had learnt it by heart. Moreover, all materials were visual and text-free. Protocols and visual materials can be found in Appendix B. Translation of the instructions by a native Mayan speaker was 
provided when needed. As mentioned, opaque curtains were installed between the columns to ensure privacy. As a result, the subjects could not see what people in front of or next to them were doing, and they were not allowed to look at those sitting behind them.

In the lab room, each subject was seated in front of the table assigned to his or her number. On the table there was one ball-pen, as well as a magazine of the participant's choice. ${ }^{10}$ The magazine was meant to induce a positive opportunity cost of spending time exerting effort; hence, participants could not open their magazines before the experiment started, between the tasks, or after the experiment ended, and they were not allowed to keep the magazine after the session.

Once the first group had completed the ability tests and the games and had answered the post-experimental question(s), the two groups quietly changed rooms without interacting (see Figure 1). The first group was then served a snack and completed the post-experimental questionnaire in the auxiliary room; the second group filled out this questionnaire, also in the auxiliary room, upon having completed its session in the field lab room. A native Mexican assistant or a Mayan native speaker helped illiterate participants fill out the questionnaire.

When both groups had completed their experimental sessions, a child randomly picked a colored card from an opaque bag in front of everybody. This card determined which of the four games would be used to calculate the payoffs. For instance, if the card indicated the One-to-One game, then this game was used for the payoffs of both Donors and Recipients. Finally, the lottery was performed in front of all the participants in order to ensure transparency of the payments calculation. The average payment was over 100 pesos, close to the daily minimum wage of an agricultural worker. ${ }^{11}$

The complete session, from the arrival to the departure of the subjects, usually lasted about three hours, and each group spent around 45 minutes in the field lab room.

\section{D. Field setting and locality selection}

The experimental field work was conducted in August 2014 in the state of Yucatán, Mexico. The choice of this location was driven by our goal to study a population of subsistence farmers, with low exposure to taxes. Accordingly, we chose to conduct the experimental work in small rural localities in Southern Yucatán, where such localities are common. Agriculture is highly heterogeneous across the state, but most of the producers, particularly in this region, operate at a small scale with an average size of plots of 1.9 ha for irrigated and 2.4ha for rain-fed agriculture (Procampo, 2013), the former being used mainly for marketed crops and the latter for corn and beans for auto-consumption. In the Southern localities, the dominant land tenure regime is the ejido, which means that decisions pertaining to land are taken collectively.

The experiment was conducted in the 8 localities shown in black in Figure 2 (see also Table 1). Each of the 8 additional localities, marked in red in the figure, was matched to one of the experimental localities to receive the amount of resources generated in the NLPG game. Matched localities are marked with the same shape as session localities. For example, an experimental session was carried out in the locality of Chican, marked with a black star, and the proceeds from the NLPG game generated in it were given to the health center of Xaya, marked with a red star. These 16 localities were selected based on a two-stage process. First, based on official data from the 2010 Mexican Population Census, collected by INEGI, and from the National Agrarian Registry

\footnotetext{
${ }^{10}$ When arriving to the field lab, participants where offered a large selection of a variety of magazines (cooking, crochet, social news, automobile, ...). The selection was attractive to the participants, both for the articles and for the pictures presented, and we included only the latest issue of each magazine.

${ }^{11}$ Although in Mexico there is no legal minimum wage for agricultural workers, we took as reference the general minimum wage in Yucatan, which was 63.7 pesos per day, while the minimum wage for an operator of agricultural machinery was 93.6 pesos per day (http://www.conasami.gob.mx).
} 
Office, we pre-selected localities that were relatively small, i.e. with less than 2,000 inhabitants. Among these small localities, we selected some where ejido tenure was prevalent to ensure homogeneity in this dimension. Second, we verified that: $(i)$ localities were indeed ejidos through interviews with their authorities, usually the president of the locality or the president of the ejido; and $(i i)$ the existence of language and infrastructure conditions suitable for conducting the experimental session.

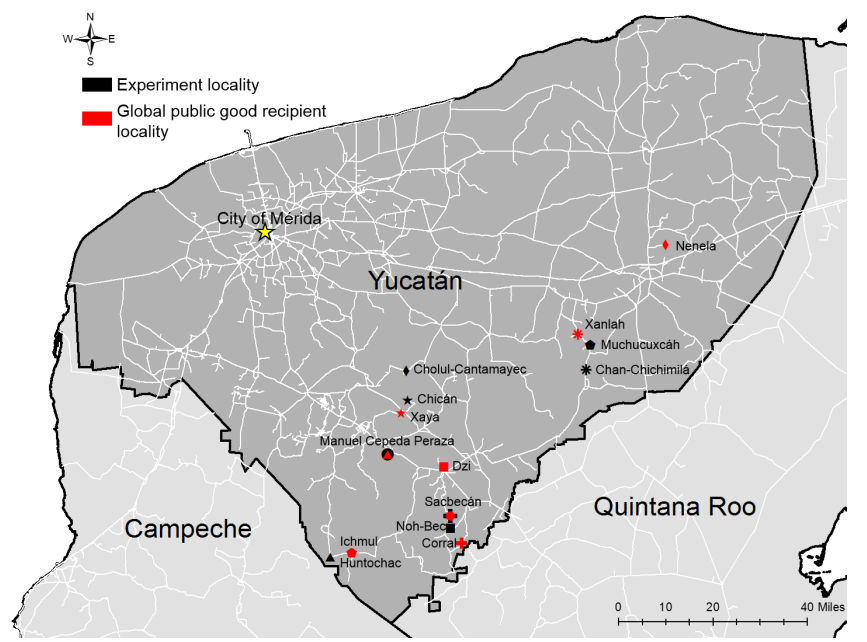

Figure 2: Map of experiment localities (marked in black) and matched localities (marked in red); Mérida is the state capital.

As shown in the map and in Table 1 below, there is significant variation in the distance between an experiment locality and its matched locality. We show later in the paper that our main results do not vary with the distance between the session and matched locality.

Table 1: Locations matching - Non-Local Public Good Game (NLPG)

\begin{tabular}{|c|c|c|c|c|c|c|c|c|}
\hline Location & Municipality & Matched village & Municipality & Distance in kms & Commuting in minutes & Know people & Visited Locality & Visited Clinic \\
\hline Manuel Cepeda Peraza & Tekax & Sacbecan & Tzucacab & 47 & 60 & 17 & 17 & 17 \\
\hline Noh-Bec & Tzucacab & Dzi & Tzucacab & 30 & 50 & 61 & 45 & 42 \\
\hline Huntochac & Tekax & Manuel Cepeda Peraza & Tekax & 80 & 94 & 45 & 36 & 21 \\
\hline Muchucuxcáh & Chankom & Ichmul & Tekax & 41 & 39 & 52 & 35 & 29 \\
\hline Chan-Chichimilá & Chikindzonot & Xanlah & Chankom & 18 & 20 & 34 & 26 & 23 \\
\hline Chicán & Tixmehuac & Xaya & Tekax & 6 & 15 & 26 & 19 & 19 \\
\hline Cholul-Cantamayec & Cantamayec & Nenela & Cantamayec & 25 & 28 & 61 & 32 & 21 \\
\hline
\end{tabular}

Table A3 shows socio-demographic indicators for our the selected localities. According to the 2010 Mexican Population Census, most of them have a population of less than 1,000 inhabitants, with the exception of Xaya, which has 1,814 inhabitants. ${ }^{12}$ Overall, the chosen localities have a high fraction of people who speak an indigenous language (above 80 percent in most cases), and low educational attainment indicators. For instance, the average years of schooling among individuals age 15 and older ranges from 4.7 to 6.7 years, and between 14.5 and 36 percent of the population in the same age group is illiterate. The relative similarity in terms of indigenous culture and other socio-demographic indicators contrasts with the religious heterogeneity between these localities. The share of the population who reports being Catholic ranges between 12.7 to practically 100 percent, with most of remaining share corresponding to non-Catholic Christians.

The chosen localities are also relatively heterogeneous with respect to several geographic and economic

${ }^{12}$ All the socio-demographic characteristics reported in Table A3 come from the 2010 Mexican Population Census as well. 
characteristics, as shown in Table A4. ${ }^{13}$ For instance, the average size of farms receiving support from Procampo, a federal cash transfer program for farmers, ranges from 1.8 to 3.8 ha in most localities, except for Noh-Bec (18.5 ha), Huntochac (11.3 ha) and Manuel Cepeda Peraza (9.1 ha). In turn, the share of ejido land destined to communal use ranges from zero to 100 percent, and in 5 out of the 16 chosen localities the level of socio-economic marginalization (SBI) is low, whereas it is medium in the remaining 11 localities. Finally, as mentioned before, in these localities the ejido is an important social and productive feature: the share of the population age 12 and older who are ejidatarios ranges from 17 to 60 percent, with the exception of Xaya, where it is only 5.7 percent.

Table A5 reports tests for differences in the means of socio-demographic and productive characteristics between the session localities and the matched localities. Most differences are small and not statistically significant, with the exception of the commuting time and distance to a major city. On average, session localities are $25 \mathrm{~km}$ and 26 minutes farther away from an important city, compared to matched localities.

Comparing the characteristics of the subjects in our experiment to those reported in the 2010 Mexican Population Census for their respective localities (see Table A6), we see that in general the characteristics of our pool are comparable to the Census locality data, with a few notable exceptions. Our pool seems to be relatively more female, less single, and more bilingual (Maya and Spanish), compared to the Census. In addition, the proportion of people born in the state of Yucatan in our sample is considerably lower than what the Census reports. Finally, a higher proportion of our subjects resides in one-room dwellings, compared to the general population of their localities.

\section{DESCRIPTIVE EVIDENCE}

The empirical analysis focuses on the within-subject effort difference, defined as the difference between the subject's effort in the NLPG game and that in the LPG game. Specifically, it examines the discrepancy between women's and men's effort differences, henceforth the gender gap in effort difference. Before turning to our regression results, however, here we present graphical evidence on the effort distributions in the LPG and the NLPG games separately, where effort is measured as completed levels. We also present the distributions of the effort differences.

First, Figure 3 shows that the overall distributions of effort in the LPG and the NLPG games are very similar. In addition, the difference in means between the two games is negligible (7.27 versus 7.41 levels completed in the LPG and NLPG games, respectively; Wilcoxon test $\mathrm{p}=0.3496)$. Thus, this graphical evidence suggests no significant differences in the effort exerted by subjects in the two games.

Second, we proceed to test whether the efforts in the LPG and NLPG games vary systematically by role, i.e. by whether the subject was allocated to the Donor or to the Recipient role in the experimental session. As shown in the left panel of Figure 4, the distribution of the effort difference is practically identical for Donors and for Recipients (Wilcoxon text $\mathrm{p}=0.9943$ ). This suggests that the distribution of preference parameters may have been different for subjects in the Donor and in the Recipient treatments. ${ }^{14}$

Turning finally to the gender gap in effort difference, the right panel of Figure 4 shows the distributions of

\footnotetext{
${ }^{13}$ The indicators in Table A4 come from the 2010 Mexican Population Census and the National Agrarian Registry Office (RAN).

${ }^{14}$ Recall from the payoffs detailed in Figure 1 that while in the Recipient treatment the smallest possible donation to the health center is $100 n$ (where $n$ is the total number of subjects), in the Donor treatment it is the largest possible donation that equals $100 \mathrm{n}$. Hence, if for subjects the marginal benefit of the donation is decreasing, Recipients would have been expected to exert a lower effort on average than Donors. The absence of a significant difference is compatible with a constant marginal benefit of donations, and/or systematic differences between the preferences of subjects in the Recipient and Donor treatments.
} 


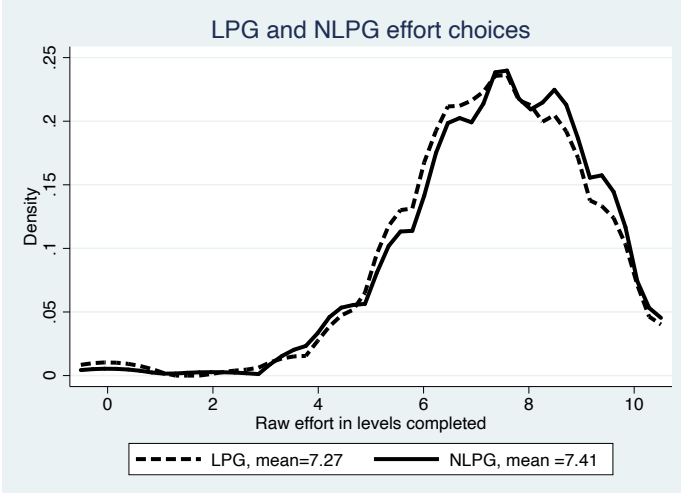

Figure 3: Distributions of effort in the LPG and NLPG games
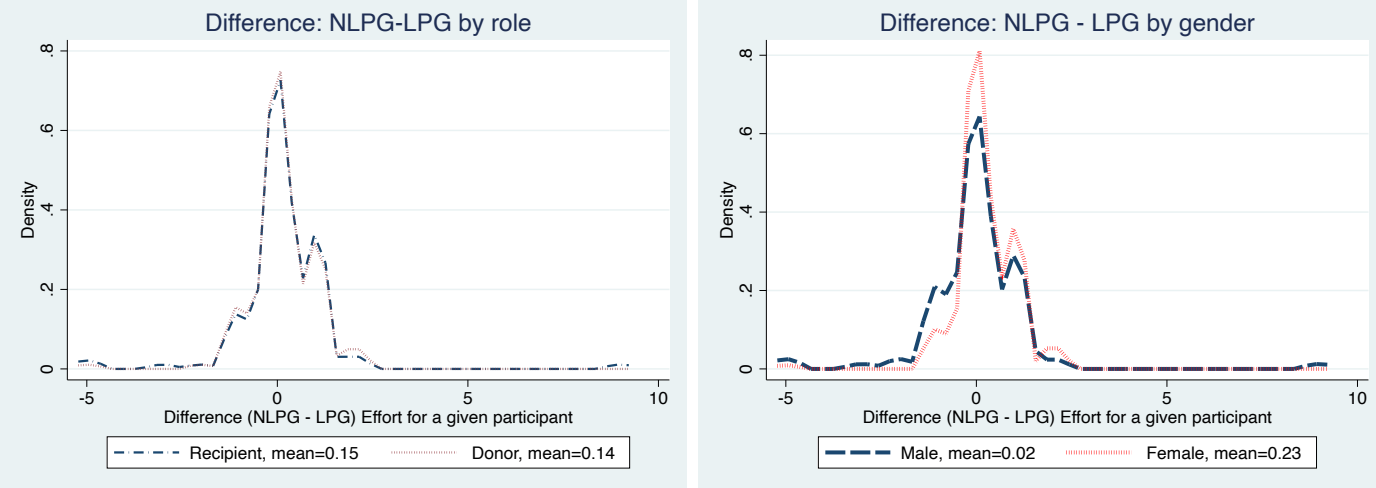

Figure 4: Distribution of the effort difference by Role (left panel) and by Gender (right panel). 
the effort difference for men and women. The mean effort difference is 0.23 levels for women, whereas it is close to zero for men (0.02), and the gender gap in effort difference is positive and statistically significant (Wilcoxon test $\mathrm{p}=0.0365)$. In sum, this suggests that women are more willing than men to exert effort for the NLPG, relative to the LPG.

Figure 5 reinforces this pattern. It shows the distributions of the effort difference, separately by the interaction of role and gender. Female subjects seem to be more willing than men to exert effort in the NLPG versus the LPG game in both roles, as discussed before, but this gender gap is larger for Donors than for Recipients. For Donors, the gender gap in effort difference is large (from -0.16 to 0.34) and statistically significant (Wilcoxon test $\mathrm{p}=0.0019$ ), whereas the opposite holds for Recipients: the gap is small (from 0.11 to 0.19 ) and not statistically significant (Wilcoxon test $\mathrm{p}=0.9034$ ).
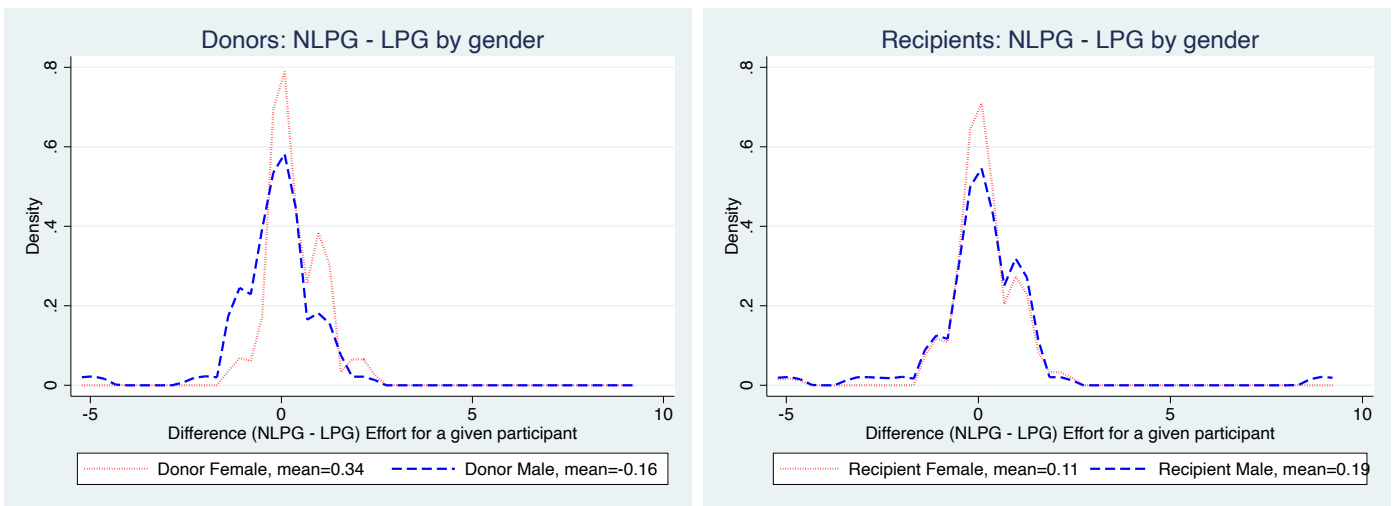

Figure 5: Distributions of effort difference by role and gender

In sum, the graphical evidence shown in this section suggests no overall difference between the effort exerted by subjects in the NLPG game compared to the LPG game. In addition, role alone does not induce differences in the relative effort exerted in these two games. Nevertheless, the figures show a significant difference by gender, with women being more willing than men to exert effort in the NLPG, compared to the LPG. This gender gap in effort between those two games seems to be larger in the Donor treatment. Thus, even though role does not seem to affect effort choices by itself, it does seem to matter when interacted with gender.

\section{Main Results}

\section{A. Empirical Specification}

To analyze the within-subject effort difference, we first estimate the following specification:

$$
\text { Effort }_{i g}=\alpha+\beta \cdot \text { Non-Local }_{g}+\gamma_{i}+\epsilon_{i g}
$$

where Effort $_{i g}$ denotes the effort of subject $i$ in game $g$; Non-Local $g$ is a dummy equal to one for the transfer game that benefits the health center of the matched locality, and zero for the LPG game, which is the reference category; $\gamma_{i}$ is a subject fixed effect, which controls for individual characteristics affecting effort that remained constant during the session, and $\epsilon_{i g}$ is an error term.

To examine the gender gap in effort difference, we add the interaction of the Non-Local dummy with a Female dummy to Equation 1 as follows:

$$
\text { Effort }_{i g}=\alpha+\beta \cdot \text { Non-Local }_{g}+\delta \cdot\left(\text { Non-Local }_{g} * \text { Female }_{i}\right)+\epsilon_{i g}
$$


where all the terms are as defined above. In this case, $\beta$ captures the mean difference in effort between the NLPG and LPG games for men, and $\beta+\delta$ captures the corresponding one for women. Thus, $\delta$ represents the gender gap in effort difference.

We estimate Equation 1 for our whole sample first, then separately for Donors and Recipients, and for men and women. We estimate Equation 2 separately for Donors and Recipients. In all our estimations of Equations 1 and 2, we cluster the standard errors at the session level to account for any correlation between outcomes in a given session.

\section{B. Regression results}

Table 2 presents our main regression results. Columns 1 to 5 present the estimates of Equation 1 for the whole sample, and then separately by role and gender, whereas Columns 6 and 7 show the estimates for Equation 2 by role.

In Column 1, the Non-Local dummy variable is positive, but not statistically significant at conventional levels, implying that on average, for the whole sample of subjects, effort exerted is similar in the NLPG game and the LPG game.

Columns 2 and 3 present separate estimations of Equation 1 for Donors and Recipients, respectively. In both columns, the estimate for the Non-Local dummy is positive, similar in magnitude and not statistically significant, confirming the observation made in the previous section that role alone does not induce prominent discrepancies in the effort difference.

Turning now to the comparison between women and men, in Columns 4 and 5, we present separate estimations for female and male subjects, pooled across roles. Column 4 shows that women complete about 0.23 levels more in the NLPG game than in the LPG game, and this estimate is significant at 5 percent. In contrast, the estimate of the Non-Local dummy is close to zero and not statistically significant for men in Column 5. Thus, on average our female subjects exert significantly more effort than when the transfer benefits the health center at the matched village instead of the health center at their own village.

Columns 6 and 7 show that this gender gap in effort difference is entirely due to the behavior of female participants in the Donor role. The Non-Local dummy alone is negative for Donors in Column 6, and positive for Recipients in Column 7, but none of them are statistically significant at conventional levels. Thus, male Donors and Recipients do not seem to put forth a significantly different effort in the two public good games. Conversely, the interaction of the Non-Local dummy with the Female dummy is positive and significant at 1 percent for Donors in Column 6, whereas it is negative, but small and not statistically significant for Recipients in Column 7. On average, female Donors complete about half a level (0.508) more than male Donors in the NLPG, relative to the LPG game. Thus, female Donors appear to be more willing than their male counterparts to exert effort when the transfer benefits the other village instead of their own. As shown in Column 7, we find no comparable gender gap in effort difference for Recipients.

\section{C. Robustness to effort measure and order of the games}

We assess the robustness of our main results, namely the gender gap in effort difference for Donors, to the order of the games in the experimental session and to the definition of effort used.

First, we examine whether our results are robust to the particular order in which the games were played during the experimental session. In all sessions, the last game was always the NLPG game, whereas the LPG 
game was either the second or third game, depending on the session. Thus, a potential concern is whether learning is the primary driver of the difference between the two public good games. Players could exert a higher effort on the NLPG game, just because by then they had already mastered the task. Figure A1 shows that, even if there is a concave shape on the evolution of effort across rounds, it reverses for the last game, especially in the case of male Donors. This shape suggests that, even in the presence of learning, male Donors decrease their effort when it benefits the health center of the neighboring locality, whereas women do not.

To further confirm the robustness of our results, we add interactions with a dummy for the game order in the session to Equation 2. Table A9 confirms that our main results hold when controlling for the order of the games. For Recipients, the estimates of the Non-Local dummy and its interaction with Female are not statistically significant (Columns 1 and 2). For Donors, the Non-Local dummy by itself is not statistically significant in Column 3, and it is marginally significant, but small and negative, in Column 4. In this latter column, the interaction of Non-Local and Female is positive and significant at 5 percent, as in our main results, although a bit smaller in magnitude, suggesting ordering might explain some of the positive gender gap for Donors, but not all of it. This seems to be supported by the estimate for the triple interaction of Non-Local with Female and Order, which is also positive and significant at 5 percent in Column 4. In Appendix A, we provide further details on learning.

Second, in our main results, our measure of effort is completed levels, which are the ones that count for the player's potential payoff, as described in our experimental protocol. Recall that, as shown in the protocol presented in Appendix B, the number of squares that must be marked to complete a given level increases with the level. Thus, in Table A10 we present additional estimates of Equation 2, obtained with two alternative measures of effort: the number of marked squares corresponding to the completed levels (Columns 1 to 3 ), and the number of squares marked in total, i.e. those corresponding to both the completed and unfinished levels (Columns 4 to 6). Even though the additional squares marked in an incomplete level do not count for the player's payoff, adding them allows us to measure the total effort she put forth up until the time for the task ran out. As shown in the Table, our main results hold: for the whole sample, the interaction of Non-Local and Female is positive and significant at conventional levels (Columns 1 and 4) and, when running separate estimations by role, this effect is entirely driven by the behavior of female Donors (Columns 2 and 5). For Recipients, the Non-Local dummy, and its interaction with Female are never significant (Columns 3 and 6), as in our main results.

\section{What EXPlains the GENDER DifFERENCE IN EFFORT BETWEen THE NLPG AND LPG GAMEs?}

In this section, we turn to analyze whether the positive gender gap in effort difference for Donors we find is driven, or varies, with selected individual characteristics of our subjects. We examine four groups of such characteristics: informal giving and receiving patterns, measures of community involvement and trust, proxies of the strength of the participant's network in her own and in the matched village, and other sociodemographic characteristics at the individual and the locality level.

For each of these variables, which we describe below, we first examine whether any unconditional mean differences by gender are statistically significant. Then, as a step further, we estimate the following specification for each of them:

$$
\begin{array}{r}
\text { Effort }_{i g}=\alpha+\beta * \text { Non-Local }_{g}+\gamma_{1} * \text { Non-Local }_{g} * \text { Female }_{i}+ \\
\gamma_{2} * \text { Non-Local }_{g} * \text { Variable }_{i}+\gamma_{3} * \text { Non-Local }_{g} * \text { Female }_{i} * \text { Variable }_{i}+\delta_{i}+\epsilon_{i g}
\end{array}
$$

where all variables are defined as above and $\mathrm{Variable}_{i}$ will be the individual characteristic considered in each 
specification. The coefficient $\gamma_{1}$ measures the gender gap in the effort difference exerted in the LPG versus the NLPG games, when Variable $i$ is equal to zero, and $\gamma_{3}$ measures the additional gap for those observations with a positive value of Variable $_{i}$ (equal to 1 in the case of dummy variables).

\section{A. Informal giving and receiving patterns}

Regarding our first set of variables, we use dummy variables for whether the participant's household gave any help to other households in the previous year, whether help was given to someone in the respondent's locality, and whether the respondent believes such help is either voluntary, due to pressure or to reciprocity. We also use dummies for whether the respondent individually received any help in the previous year, whether her household received any help in the same period, whether such help was sporadic, and whether it came from the same locality where she lives. Panel A of Table A8 reports the mean differences in these variables between our female and male subjects, most of which are not statistically significant. About half of the respondents' households, both male and female, gave help during the previous year, and most report that this help was sporadic (88-90 percent) and given to someone living in their own locality (67-80 percent). Although female respondents are 13 percentage points more likely than men to report that the help given was to someone in their own locality, this difference is not statistically significant. The only two significant gender differences in this panel pertain the reported motives for giving. ${ }^{15}$ Women are 11 percentage points less likely than men to report that the help given by her household was voluntary, and 12 percentage points more likely to report that it was due to reciprocity. None of the mean differences in receiving patterns between men and women are statistically significant. Thus, men and women in our sample do not seem to differ in their mean giving and receiving patterns, except for their reported motives for giving,

Table 4 shows our estimation results for equation 3 using the same measures of giving and receiving patterns. Overall, our main results remain after including each of these variables. For Donors, Panel A shows that $\gamma_{1}$ is positive after including each of these variables, and mostly statistically significant at conventional levels. On the contrary, Panel B shows that, for Recipients, most estimates of $\gamma_{1}$ are not statistically significant, as in our main results; the few exceptions, are in the columns in which we have only half of the observations. The same caveat applies to the few estimates of $\gamma_{3}$ that are statistically significant in both panels.

\section{B. Community involvement and trust}

Another possible explanation for our main results is that women are more socially involved in the community and have higher trust on institutions, compared to men, thus they are also more willing to exert effort for others. As measures of community involvement and trust, we use a dummy for whether the respondent believes the people in her locality cooperate to solve their problems most of the time, the share of respondents in her locality who also think so, the number of organizations in which the respondent participated in the last 12 months (social, political, religious), the number of community celebrations in which she participates; dummies for whether the respondent believes (i) she can trust most people, (ii) most people would treat her fairly, (iii) effort is rewarded with higher income most of the time; dummies for whether she has some confidence that the government will adequately spend tax revenues, and for whether she has high confidence on the same issue. ${ }^{16}$

\footnotetext{
${ }^{15}$ Note that the number of observations drops by half in some of these variables because the characteristics of the help given or received are available only for participants who reported that they did give or receive informal help.

${ }^{16}$ The share of respondents in her locality who also believe that people there cooperate to solve their problems most of the time reflects only the opinions of those participating in the session. Our questionnaire asks whether the respondent attends or collaborates in different broad types of community celebrations (school, civic, traditional, cultural and religious). For our variable of number of community celebrations, we just add up all the different kinds of celebrations in which the respondent participates.
} 
As shown in Panel B of Table A8, men and women have statistically similar unconditional means in these measures, except for the number of organizations in which they participate and the trust in most people. On average, in the 12 months previous to the survey, women participated in 2.2 organizations of different kinds, whereas men participated in 1.8 of them. This difference is statistically significant at 5 percent. On other hand, women are 18.1 percentage points less likely than men to believe that generally you can trust most people, and the difference is statistically significant at 1 percent. Thus, on average, women do seem to be more socially involved in their community, but also display less trust towards other people in general, compared to men.

However, when including these two measures, and their interaction with Non-Local and Female, in our regressions, they do not seem to explain our main results. In Table $5, \gamma_{1}$ is still positive and significant for Donors in almost all specifications in Panel A, as in our main results. Moreover, in that same panel, none of the estimates of $\gamma_{3}$ are statistically significant, including those for the number of organizations in which the subject participates and the dummy for whether she believes she can trust most people. The only exception is the interaction of the Non-Local dummy with Female and the dummy for having some trust in government spending taxes adequately (column 8), which is marginally significant. Also, in that column, the estimate of $\gamma_{1}$ is positive, but not significant. This is evidence suggesting that, for Donors, most of the positive gender gap in effort between the two public good games could be due to the behavior of women who have some trust in the government.

Panel B of Table 5 shows, once again, that most of the estimates of $\gamma_{1}$ are not statistically significant at conventional levels for Recipients. The same is observed for the estimates of $\gamma_{3}$. The only two exceptions are in columns 7 and 8. In column 7, we find no significant gender gap in effort between the NLPG and LPG games, as in most of the other columns, but the triple interaction of Non-Local, Female and the dummy for whether the respondent believes that effort is rewarded with higher income most of the time is negative and significant at 5 percent. Thus, women who believe so, exert less effort in the NLPG game versus the LPG game, compared to men. In column 8 , the estimate for $\gamma_{1}$ is positive, whereas the estimate for the triple interaction of Non-Local, Female and the dummy for having some trust in the way the government spends taxes is negative, and both estimates are marginally significant. These results would suggest a positive gender gap in the effort difference for Recipients that have no trust in the government, and no significant gap for those who have at least some trust in it.

\section{C. Knowledge of other session participants and of the matched locality}

A willingness to exert effort in either LPG or NLPG could be driven by prosocial preferences, such as altruism (Becker, 1974). If so, a subject's effort towards the health center in the participant's own locality and towards that in the matched locality should be a function of the strength of the subject's network in each of them. We consider the following variables as proxies for the participant's network in her own locality: whether the participant knows almost all or all of the other participants in the session, whether half or more of the session participants belong to her family, whether she shares daily activities with half or more of them. Our proxies for the strength of the participant's network in the matched locality are dummies for whether she knows the other locality, whether she has visited the other locality and for whether she has actually been in the health clinic of the matched locality.

Panel C of Table A8 shows that for all these proxies of social networks in both localities, the unconditional mean differences are small and not statistically significant at conventional levels.

In Table 6, we examine whether our main regression results are due to women having stronger local and

non-local networks. The first three columns in Panel A show that the positive gender gap in effort in the two 
public good games for Donors is not driven by whether the participant knows most people in the session, by whether half or more of them belong to her family, or by whether she shares daily activities with half or more of them. Similarly, columns 4 to 6 show that such gap is not due either to knowing the other village, having been there or actually having been to its health center. In all columns, except for the first, the estimate for $\gamma_{1}$ is positive, and statistically significant at 5 percent, whereas $\gamma_{3}$ is smaller and not significant. In the first column, $\gamma_{1}$ is positive, and larger in absolute value, than in the other columns, but not statistically significant. This might be due to the fact that a high share of observations have a value of 1 in the dependent variable in that column (87.5\%), compared to the rest (15\% to $50 \%$, depending on the column). In contrast, Panel B shows that, for Recipients none of the key interactions are statistically significant, which is consistent with our main results.

\section{D. Individual sociodemographic characteristics}

We also analyze whether our results are mostly explained by other standard sociodemographic characteristics of our subjects, like age, dummies for having at least secondary education, for being married, and for being born in the municipality where the session took place, number of siblings, number of children, dummies for whether someone in the participant's household receives Procampo or Oportunidades (the largest cash transfer programs targeting rural localities), the number of government programs that the participant's household receives benefits from, and dummies for having a household asset index in lower than the 25th percentile or higher than the 75th percentile. $^{17}$

The unconditional mean differences between men and women are reported in Panel D of Table A8. Most of these differences are not statistically significant, except for the probability of having at least some secondary education, the probability of being married, and the participant's number of children. About 48 percent of men have at least some secondary education, compared to only 26 percent of women, and this difference is significant at 1 percent. Women are 10 percentage points more likely to be married compared to men, and this difference is marginally significant. On average, among the participants in our experiment women have more children (3.8) than men (3.0), and this difference is significant at 5 percent. In sum, on average men seem to be more educated, less likely to be married and they have slightly fewer children, compared to women. In theory, this difference could help explain why women in our experiment would be more willing than men to exert effort in the LPG, since women may care more than men about their own children's welfare, ${ }^{18}$ and additional earnings to the local health center would likely benefit the subjects' children directly. A discrepancy in parental altruism between men and women would thus imply that, ceteris paribus, women should be more willing than men to exert effort in the LPG. However, such a discrepancy could not explain the gender gap in the effort difference that we observe among Donors in our experiment, since the additional earnings in the NLPG did not benefit the subjects' own children directly.

To complete the picture, in Table 7 we examine whether our results vary with the sociodemographic characteristics described above. For Donors, panel A shows all positive $\gamma_{1}$ estimates, which are statistically significant at conventional levels in 8 out of the 12 columns. For $\gamma_{3}$, we find mostly not significant estimates, except for

\footnotetext{
${ }^{17}$ In our sample, about 62 and 85 percent of subjects report that their household receives support from Procampo and Oportunidades, respectively. On average, our subjects' households receive support from 2.5 government programs.

${ }^{18}$ Such a hypothesis is consistent with evolutionary theory (for a survey on the evolution of parental altruism, see Alger and Cox (2013)). It further finds empirical support in a number of studies, which show that putting more money in the hands of mothers improves outcomes for children (see, e.g., Lundberg et al. (1997), Schady and Rosero (2008)). Relatedly, a growing literature examines whether female and male politicians allocate resources towards health services differently (see, e.g., Bhalotra and ClotsFigueras (2014)). Even more strikingly, in their review of studies of the effects of kin availability on child survival, anthropologists Sear and Mace (2008) find that while the death of the mother always hurts the prospects for child survival, the death of the father does so in only one third of the studies.
} 
three cases, all of them related with participation in government programs. Column 7 shows that the positive gender gap in effort between the two public good games is due to women who participate in the Oportunidades program, a conditional cash transfer program for poor rural households. In that column $\gamma_{1}$ is not significant, and it is smaller than the corresponding estimates in other columns, whereas $\gamma_{3}$ is positive and significant at 10 percent. Oportunidades, formerly known as Progresa, has two features that are consistent with these estimates. First, the transfer from the program is paid to the mother or most senior woman in the household. Second, part of the transfer is conditioned on complying with scheduled health checks for children and adults in beneficiary households. Thus, Oportunidades beneficiaries, women who likely use health services relatively often, are those who are more willing to exert effort for the clinic at the matched locality, compared to men. We do not find a similar pattern for the receipt of noncontributory pensions, which are unconditional cash transfers paid to the rural elderly (column 8). Column 9 shows that the positive effort gender gap is larger for Donors who do not participate in the Procampo program, compared to those who do, which suggests that it is larger for women from landless households, given that this program pays a transfer per acre of land held by the household. Column 10 shows that the positive gender gap is also larger for those who participate in fewer government programs, suggesting that higher participation in such programs decreases the relative willingness of women to exert effort, compared to men. For Recipients, once again we find no significant estimates for $\gamma_{1}$ and $\gamma_{3}$, except for a positive and marginally significant estimate for having secondary education.

\section{E. Locality sociodemographic characteristics}

Finally, an alternative driver of the gender effect could come from both genders reacting differently to the differences between own and matched locality. As reported in Table A5, the difference in aggregate between local and matched localities is not statistically significant, but in Tables A3 and A4 we see that there are some (small) differences between the localities in a given pair.

Thus, to complement our analysis so far, we estimate similar specifications to examine whether our results are due to the differences in the sociodemographic characteristics between the session and matched localities. In these specifications, we substitute Variable $_{i}$ in equation 3 with each of the locality characteristics described below. We use the ratio of a given indicator in the matched locality to that of the session locality, for the following indicators: total population, share of individuals who identify themselves as Catholic, average farm size, and share of the population age 12 years and older who are Procampo beneficiaries. We also consider measures of distance from each locality to a major city, and between the session and matched localities, both in kilometers and minutes of travel. In our sample of localities, we have extreme values for the share of ejido land that is destined to common use: either we have localities with a share above 0.60 , or localities with a share close to zero. Thus, we use four dummy variables capturing whether such share is low in the session locality and also low in the matched locality (LL), low and high (LH), high and low (HL), or high and high (HH). In Appendix A, Table 8 shows that our main results do not vary with any of these locality characteristics.

In sum, unconditional mean differences between our male and female participants are mostly not statistically significant, except for a few cases: compared to men, women are less likely to report that informal help given is voluntary, and more likely to report that it is due to reciprocity; they participate in more organizations, but they are less likely to believe that you can trust more people; they are less likely to have secondary education, more likely to be married, and they have more children.

In addition, the positive gender gap in effort between the two public good games does not vary with informal giving and receiving patters, measures of community involvement and trust, proxies for the strength of the local and non-local networks of players, or other standard sociodemographic characteristics at the individual level, except for the trust of the participant in the way the government spends taxes, and the participation in 
government programs.

\section{F. Are women aware of their higher willingness to exert effort for others?}

As a final piece of analysis, we examine whether the willingness of a given female participant to exert effort in the LPG versus NLPG game is affected by the gender composition of her fellow participants. Such gender composition could affect the individual decision to exert effort if the player expects other participants to exert more or less effort, depending on their gender. Thus, we estimate equation 3 using two variables for gender composition: the share of women in the experimental session and the share of women in the room. The first measure pools Donors and Recipients in a given session when calculating the share, whereas the second captures the gender composition within each of these treatments. Sessions had on average $59 \%$ of female participants, with a minimum of $43 \%$ and a maximum of $74 \%$, and the distribution in the two treatments in each session is similar.

Columns 1 to 3 in Table 3 show the results for the share of women in the session. Once again, we only find a positive, and statistically significant, gender gap in effort for Donors in column 2. In that same column, the triple interaction of Female with Non-Local and the share of women in the session is negative and statistically significant at 5 percent. An increase of one standard deviation (0.3) in this share would decrease the gender effort gap for Donors by 0.39 levels. In columns 4 to 5 , we still find a positive gender gap in effort for Donors, and a negative effect of the share of women in the room, instead of the session, but none of these effects are statistically significant. These findings suggest that women might be aware of their higher willingness to exert effort for a public good that does not benefit them directly, compared to men, and so they reduce their individual effort the more female their environment is. To explain the difference in results between the two gender composition measures, recall that the group of participants hung out for some time outside of the room, while we were waiting for all of them to arrive and carrying out the final preparations for the session, and so they had plenty of time to look at each other. After this, they were randomly divided into two groups and the first one immediately entered the room, where participants were all the time facing the front of the room and had dividers between them to ensure privacy. Thus, it was easier for participants to become aware of the gender composition of the session, than the gender composition of the room where they actually played.

\section{Concluding Discussion}

Are women more inclined than men to contribute to public goods from which they do not benefit personally? Our data from a lab-in-the-field experiment, in which subjects choose to exert real effort to increase the contributions to health centers existing in other localities and their own, suggests that this may be the case. Consistent with the payoff structure used in the experiment, we find a positive and statistically significant gender gap in the difference between effort in the LPG and NLPG games for Donors, whose effort could have the effect of adding money to the amount given to the health centers. This implies that female Donors are more willing than their male counterparts to exert effort when it benefits the health center of another locality, compared to when it benefits the one in their own locality. In contrast, the gender effort gap between those two games for Recipients, whose effort could have the effect of avoiding to withdraw money from the contributions to health centers, is close to zero and not statistically significant. Although we have not formally established the external validity of these results, we find that the gender gap in relative effort for Donors is mostly due to women who report having at least some trust in the way the government spends taxes (see Section 6.2), and to women who benefit from a government program that targets women and fosters health care use (see Section 6.4), which lends credibility to them. 
As mentioned in the introduction, the evidence on gender differences regarding monetary contributions in the classic public goods game in laboratory experiments is mixed. By contrast, studies that examine gender differences in the willingness to pay taxes show that women's willingness exceeds that of men more consistently. ${ }^{19}$ Our study complements these two strands of the literature by using a real-effort experiment in which proceeds went to actual public goods. As a caveat, the motivation of an individual for complying with the tax code might be different from the one for voluntarily exerting effort to contribute to a public good (s)he does not benefit from personally. The fear of being caught and punished might play a role in the former, whereas not in the latter, especially when the effort choice is unobservable to others, as in our experiment. Thus, from our results, we cannot generally conclude that women are more willing than men to pay taxes in the population that we studied. Nevertheless, the evidence we find suggests that it would be interesting to disentangle the relative contribution of these two motivations to the gender difference in tax compliance found in the literature. Furthermore, while discrepancies in the behavior of women and men may be driven by social norms and culture (Fernández, 2013), evolutionary theory suggests that they may also stem from deeper differences (Eswaran, 2014). Our findings are in line with the evolutionary theory which predicts that in- vs out-group attitudes are expected to differ between men and women, with men being expected to favor in-group members to a larger extent than women. ${ }^{20}$ Further research on the competing explanations for gender differences in behavior is due.

\footnotetext{
${ }^{19}$ For analysis of attitudes towards taxes based on the World Values Survey, see Torgler and Schneider (2005), and for a large-scale tax experiment on students, see Attoma et al. (2017).

${ }^{20}$ According to this "male warrior hypothesis," men should be expected to have evolved to be more aggressive than women towards other "groups" than towards their own for several reasons. First, individual male-male competition for mates may historically have been more severe between groups than within groups, because when such competition occurred within groups, a man may have harmed his relatives (Manson et al., 1991, Low, 1993, Micheletti et al., 2018). Moreover, the level of aggression displayed by same-sex coalitions from the same group towards out-group coalitions should also be expected to have evolved to be higher for men than for women. The reason is that it is less costly for the group, in terms of average reproductive success, to lose males than females, because females are the limiting resource in a sexually reproducing species like Homo sapiens (Tooby and Cosmides, 1988).
} 


\section{References}

Adams, R. B. and Funk, P. (2012). Beyond the glass ceiling: Does gender matter? Management Science, $58(2): 219-235$.

Alger, I. and Cox, D. (2013). The evolution of altruistic preferences: mothers versus fathers. Review of Economics of the Household, 11(3):421-446.

Alger, I., Miquel-Florensa, J., Juarez, L., and Juarez-Torres, M. (2019). Do informal transfers induce lower efforts? evidence from lab-in-the-field experiments in rural mexico. Economic Development and Cultural Change.

Angelucci, M., De Giorgi, G., Rangel, M., and Rasul, I. (2009). Village economies and the structure of extended family networks. The BE Journal of Economic Analysis \& Policy, 9(1).

Angelucci, M., De Giorgi, G., Rangel, M. A., and Rasul, I. (2010). Family networks and school enrolment: Evidence from a randomized social experiment. Journal of public Economics, 94(3-4):197-221.

Attoma, J. D., Volintiru, C., and Steinmo, S. (2017). Willing to share ? Tax compliance and gender in Europe and America. Research \& Politics, 4(2):1-10.

Beaman, L., Duflo, E., Pande, R., and Topalova, P. (2012). Female leadership raises aspirations and educational attainment for girls: A policy experiment in india. science, 335(6068):582-586.

Becker, G. S. (1974). A theory of social interactions. Journal of Political Economy, 82(6):1063-1093.

Bertrand, M. (2011). New perspectives on gender. In Handbook of labor economics, volume 4, pages 1543-1590. Elsevier.

Besley, T. and Persson, T. (2014). Why do developing countries tax so little? Journal of Economic Perspectives, 28(4):99-120.

Bhalotra, S. and Clots-Figueras, I. (2014). Health and the political agency of women. American Economic Journal: Economic Policy, 6(2):164-97.

Brown-Kruse, J. and Hummels, D. (1993). Gender effects in laboratory public goods contribution: Do individuals put their money where their mouth is? Journal of Economic Behavior ES Organization, 22(3):255-267.

Carpenter, J. and Seki, E. (2011). Do social preferences increase productivity? field experimental evidence from fishermen in toyama bay. Economic Inquiry, 49(2):612-630.

Croson, R. and Gneezy, U. (2009). Gender differences in preferences. Journal of Economic literature, 47(2):44874.

DellaVigna, S., List, J. A., Malmendier, U., and Rao, G. (2013). The importance of being marginal: Gender differences in generosity. American Economic Review, 103(3):586-90.

Dupas, P. and Robinson, J. (2013). Savings Constraints and Microenterprise Development: Evidence from a Field Experiment in Kenya. American Economic Journal: Applied Economics, 5(1):163-192.

Erard, B. and Feinstein, J. S. (1994). Honesty and evasion in the tax compliance game. The RAND Journal of Economics, pages 1-19.

Eswaran, M. (2014). Why Gender Matters in Economics. Princeton University Press, Princeton, NJ. 
Fernández, R. (2013). Cultural Change as Learning : The Evolution of Female Labor Force Participation over a Century. American Economic Review, 103(1):472-500.

Field, E., Holland, A., Pande, R., et al. (2016). Microcredit: Points of promise. Technical report.

Gertler, P., Patrinos, H., and Rubio-Codina, M. (2006). Empowering parents to improve education: Evidence from rural Mexico. The World Bank.

Kugler, A. and Kugler, M. (2009). Labor market effects of payroll taxes in developing countries: evidence from colombia. Economic development and cultural change, 57(2):335-358.

Levitt, S. D. and List, J. A. (2007). What do laboratory experiments measuring social preferences reveal about the real world? Journal of Economic perspectives, 21(2):153-174.

Low, B. S. (1993). An evolutionary perspective on war. In Jacobson, H. and Zimmerman, W., editors, Behavior, Culture, and Conflict in World Politics, pages 13-56. University of Michigan Press, Ann Arbor, MI.

Lundberg, S. J., Pollak, R. A., and Wales, T. J. (1997). Do husbands and wives pool their resources? evidence from the united kingdom child benefit. Journal of Human resources, 32(3).

Manson, J. H., Wrangham, R. W., Boone, J. L., Chapais, B., Dunbar, R., Ember, C. R., Irons, W., Marchant, L., McGrew, W., Nishida, T., et al. (1991). Intergroup aggression in chimpanzees and humans [and comments and replies]. Current anthropology, 32(4):369-390.

Mascagni, G. (2018). From the lab to the field: A review of tax experiments. Journal of Economic Surveys, $32(2): 273-301$.

Micheletti, A. J., Ruxton, G. D., and Gardner, A. (2018). Why war is a man's game. Proceedings of the Royal Society B: Biological Sciences, 285(1884):20180975.

Millán, T. M., Barham, T., Macours, K., Maluccio, J. A., and Stampini, M. (2019). Long-Term Impacts of Conditional Cash Transfers: Review of the Evidence. The World Bank Research Observer, 34(1):119-159.

Mohdali, R., Isa, K., and Yusoff, S. H. (2014). The impact of threat of punishment on tax compliance and non-compliance attitudes in malaysia. Procedia-Social and Behavioral Sciences, 164:291-297.

Niederle, M. (2017). A gender agenda: a progress report on competitiveness. American Economic Review, 107(5):115-19.

Nowell, C. and Tinkler, S. (1994). The influence of gender on the provision of a public good. Journal of Economic Behavior 83 Organization, 25(1):25-36.

Perez-Truglia, R. and Troiano, U. (2016). Shaming tax delinquents: Evidence from a field experiment in the united states. SSRN Scholarly Paper. Rochester, NY: Social Science Research Network, 1.

Schady, N. and Rosero, J. (2008). Are cash transfers made to women spent like other sources of income? Economics Letters, 101(3):246-248.

Sear, R. and Mace, R. (2008). Who keeps children alive? a review of the effects of kin on child survival. Evolution and human behavior, 29(1):1-18.

Slemrod, J. (2007). Cheating ourselves: The economics of tax evasion. Journal of Economic Perspectives, $21(1): 25-48$. 
Tooby, J. and Cosmides, L. (1988). The evolution of war and its cognitive foundations. Institute for evolutionary studies technical report, 88(1):1-15.

Torgler, B. and Schneider, F. (2005). Attitudes towards paying taxes in Austria: An empirical analysis. Empirica, 32(2):231-250. 


\section{Main TABles}

Table 2: Effort exerted in NLPG and LPG games

\begin{tabular}{|c|c|c|c|c|c|c|c|}
\hline Sample: & $\begin{array}{l}\text { (1) } \\
\text { All }\end{array}$ & $\begin{array}{c}(2) \\
\text { Donors }\end{array}$ & $\begin{array}{c}(3) \\
\text { Recipients }\end{array}$ & $\begin{array}{c}(4) \\
\text { Female }\end{array}$ & $\begin{array}{c}(5) \\
\text { Male }\end{array}$ & $\begin{array}{c}(6) \\
\text { Donors }\end{array}$ & $\begin{array}{c}(7) \\
\text { Recipients }\end{array}$ \\
\hline Non-Local & $\begin{array}{c}0.1475+ \\
(0.091)\end{array}$ & $\begin{array}{c}0.1452 \\
(0.102)\end{array}$ & $\begin{array}{c}0.1500 \\
(0.120)\end{array}$ & $\begin{array}{c}0.2361^{* *} \\
(0.073)\end{array}$ & $\begin{array}{l}0.0200 \\
(0.165)\end{array}$ & $\begin{array}{c}-0.1667+ \\
(0.097)\end{array}$ & $\begin{array}{c}0.1923 \\
(0.263)\end{array}$ \\
\hline Non-Local * Female & & & & & & $\begin{array}{c}0.5088^{* * *} \\
(0.074)\end{array}$ & $\begin{array}{c}-0.0747 \\
(0.301)\end{array}$ \\
\hline Constant & $\begin{array}{c}7.2705^{* * *} \\
(0.045)\end{array}$ & $\begin{array}{c}7.2016^{* * *} \\
(0.051)\end{array}$ & $\begin{array}{c}7.3417^{* * *} \\
(0.060)\end{array}$ & $\begin{array}{c}7.3819^{* * *} \\
(0.036)\end{array}$ & $\begin{array}{c}7.1100^{* * *} \\
(0.082)\end{array}$ & $\begin{array}{c}7.2016^{* * *} \\
(0.048)\end{array}$ & $\begin{array}{c}7.3417^{* * *} \\
(0.059)\end{array}$ \\
\hline Observations & 488 & 248 & 240 & 288 & 200 & 248 & 240 \\
\hline$R^{2}$ & 0.018 & 0.028 & 0.014 & 0.082 & 0.000 & 0.109 & 0.014 \\
\hline Number of players & 244 & 124 & 120 & 144 & 100 & 124 & 120 \\
\hline
\end{tabular}

Table 3: Games comparison and session composition

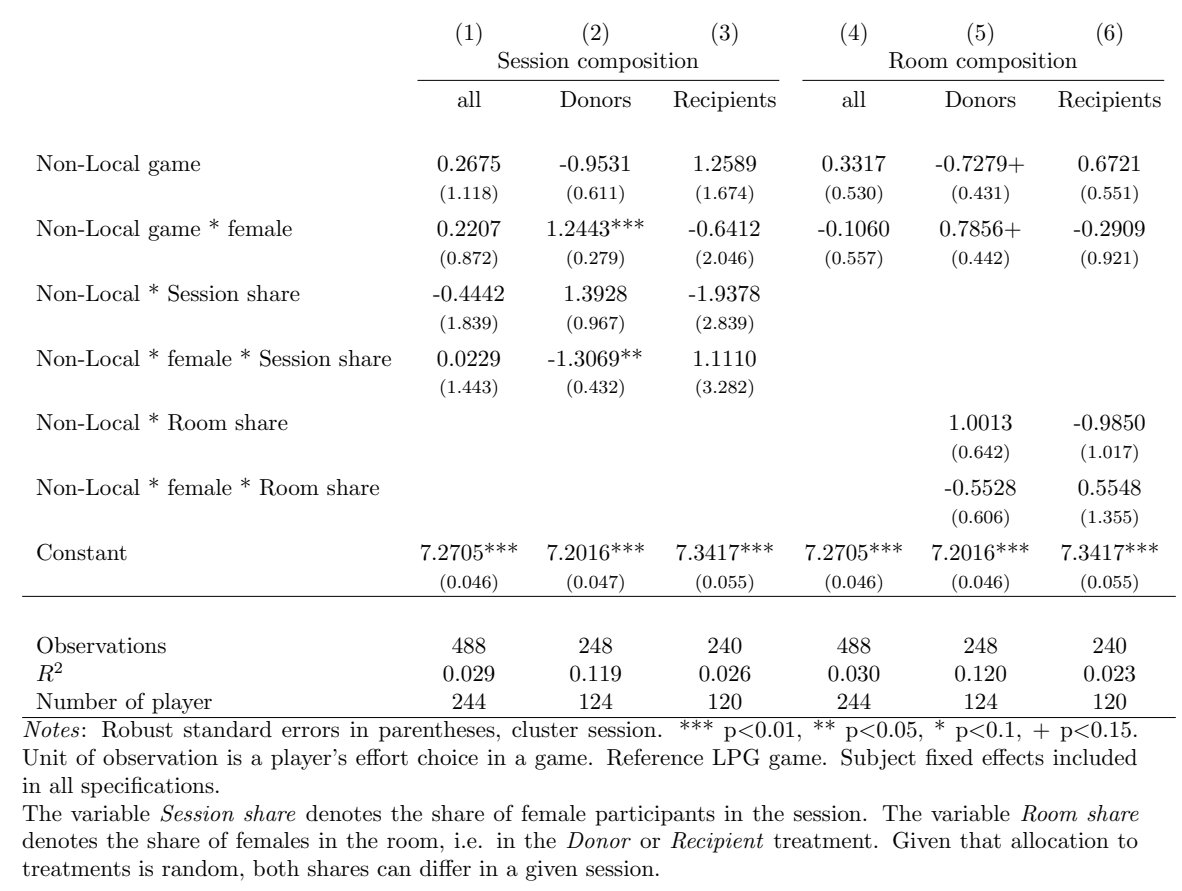


Table 4: Interaction with giving and receiving patterns

\begin{tabular}{|c|c|c|c|c|c|c|c|c|c|c|}
\hline Variable interacted: & $\begin{array}{c}\text { (1) } \\
\mathrm{HH} \text { giving }\end{array}$ & $\begin{array}{c}(2) \\
\text { Give out } \\
\end{array}$ & $\begin{array}{c}\text { (3) } \\
\text { Give same }\end{array}$ & $\begin{array}{c}\text { (4) } \\
\text { Give voluntary }\end{array}$ & $\begin{array}{c}\text { anel A: Donors } \\
\quad(5) \\
\text { Give pressure }\end{array}$ & $\begin{array}{c}(6) \\
\text { Give reciprocity }\end{array}$ & $\begin{array}{l}(7) \\
\text { Ind. received } \\
\end{array}$ & $\begin{array}{c}(8) \\
\text { HH received }\end{array}$ & $\begin{array}{c}(9) \\
\text { Received out }\end{array}$ & $\begin{array}{c}(10) \\
\text { Received same }\end{array}$ \\
\hline Non-Local & $\begin{array}{l}0.0000 \\
(0.155)\end{array}$ & $\begin{array}{c}-0.6667^{*} \\
(0.296)\end{array}$ & $\begin{array}{c}-0.0909 \\
(0.252)\end{array}$ & $\begin{array}{c}-0.0000 \\
(0.513)\end{array}$ & $\begin{array}{c}-0.0385 \\
(0.160)\end{array}$ & $\begin{array}{c}-0.1111 \\
(0.179)\end{array}$ & $\begin{array}{c}-0.1471 \\
(0.173)\end{array}$ & $\begin{array}{l}0.0455 \\
(0.213)\end{array}$ & $\begin{array}{c}-1.3333+ \\
(0.773)\end{array}$ & $\begin{array}{l}0.1333 \\
(0.200)\end{array}$ \\
\hline Non-Local $*$ Female & $\begin{array}{c}0.3571^{* *} \\
(0.143)\end{array}$ & $\begin{array}{c}0.6667^{*} \\
(0.296)\end{array}$ & $\begin{array}{l}0.4242 \\
(0.406)\end{array}$ & $\begin{array}{l}0.1111 \\
(0.577)\end{array}$ & $\begin{array}{c}0.3385^{* *} \\
(0.121)\end{array}$ & $\begin{array}{c}0.5911^{* * *} \\
(0.126)\end{array}$ & $\begin{array}{c}0.4804^{* *} \\
(0.167)\end{array}$ & $\begin{array}{c}0.3260+ \\
(0.185)\end{array}$ & $\begin{array}{c}2.1667^{* *} \\
(0.756)\end{array}$ & $\begin{array}{c}0.2667+ \\
(0.145)\end{array}$ \\
\hline Non-Local * Variable & $\begin{array}{c}-0.0690 \\
(0.196)\end{array}$ & $\begin{array}{c}0.6667^{*} \\
(0.291)\end{array}$ & $\begin{array}{l}0.0321 \\
(0.212)\end{array}$ & $\begin{array}{c}-0.0800 \\
(0.471)\end{array}$ & $\begin{array}{c}-0.4615 \\
(0.330)\end{array}$ & $\begin{array}{c}1.1111^{* * *} \\
(0.179)\end{array}$ & $\begin{array}{c}-0.0672 \\
(0.421)\end{array}$ & $\begin{array}{c}-0.3916 \\
(0.278)\end{array}$ & $\begin{array}{l}1.1754 \\
(0.917)\end{array}$ & $\begin{array}{c}-1.1333+ \\
(0.669)\end{array}$ \\
\hline Constant & $\begin{array}{c}7.1639^{* * * *} \\
(0.054) \\
\end{array}$ & $\begin{array}{c}7.4138^{* * *} \\
(0.074) \\
\end{array}$ & $\begin{array}{c}7.4667^{* * *} \\
(0.079) \\
\end{array}$ & $\begin{array}{c}7.4667^{* * *} \\
(0.078) \\
\end{array}$ & $\begin{array}{c}7.4667^{* * *} \\
(0.076) \\
\end{array}$ & $\begin{array}{c}7.4667^{* * *} \\
(0.075) \\
\end{array}$ & $\begin{array}{c}7.2016^{* * *} \\
(0.048) \\
\end{array}$ & $\begin{array}{c}7.2033^{* * *} \\
(0.049) \\
\end{array}$ & $\begin{array}{c}7.5238^{* * *} * \\
(0.045) \\
\end{array}$ & $\begin{array}{c}7.5082^{* * *} \\
(0.047) \\
\end{array}$ \\
\hline $\begin{array}{l}\text { Observations } \\
R^{2} \\
\text { Number of player }\end{array}$ & $\begin{array}{c}244 \\
0.133 \\
122 \\
\end{array}$ & $\begin{array}{c}116 \\
0.138 \\
58 \\
\end{array}$ & $\begin{array}{c}120 \\
0.096 \\
60 \\
\end{array}$ & $\begin{array}{c}120 \\
0.113 \\
60 \\
\end{array}$ & $\begin{array}{c}120 \\
0.128 \\
60 \\
\end{array}$ & $\begin{array}{c}120 \\
0.176 \\
60 \\
\end{array}$ & $\begin{array}{c}248 \\
0.109 \\
124 \\
\end{array}$ & $\begin{array}{c}246 \\
0.125 \\
123 \\
\end{array}$ & $\begin{array}{c}126 \\
0.274 \\
63 \\
\end{array}$ & $\begin{array}{c}122 \\
0.226 \\
61 \\
\end{array}$ \\
\hline Variable interacted: & $\begin{array}{c}\text { (1) } \\
\mathrm{HH} \text { giving }\end{array}$ & $\begin{array}{c}\text { (2) } \\
\text { Give out }\end{array}$ & $\begin{array}{c}(3) \\
\text { Give same }\end{array}$ & $\begin{array}{c}\text { (4) } \mathrm{Pa} \\
\text { Give voluntary }\end{array}$ & $\begin{array}{c}\text { nel B: Recipients } \\
\text { (5) } \\
\text { Give pressure }\end{array}$ & $\begin{array}{l}(6) \\
\text { Give reciprocity }\end{array}$ & $\begin{array}{l}(7) \\
\text { Ind. received }\end{array}$ & $\begin{array}{c}(8) \\
\text { HH received }\end{array}$ & $\begin{array}{c}(9) \\
\text { Received out }\end{array}$ & $\begin{array}{c}(10) \\
\text { Received same }\end{array}$ \\
\hline Non-Local & $\begin{array}{c}0.6923+ \\
(0.418)\end{array}$ & $\begin{array}{c}-2.0000 \\
(1.359)\end{array}$ & $\begin{array}{c}-0.1667 \\
(0.182)\end{array}$ & $\begin{array}{c}1.0000^{* * *} \\
(0.000)\end{array}$ & $\begin{array}{c}-0.4348+ \\
(0.234)\end{array}$ & $\begin{array}{c}-0.5000^{*} \\
(0.227)\end{array}$ & $\begin{array}{l}0.1935 \\
(0.492)\end{array}$ & $\begin{array}{l}0.4286 \\
(0.542)\end{array}$ & $\begin{array}{l}0.3333 \\
(0.297)\end{array}$ & $\begin{array}{l}0.2941 \\
(0.352)\end{array}$ \\
\hline Non-Local $*$ Female & $\begin{array}{c}-0.6611 \\
(0.577)\end{array}$ & $\begin{array}{l}2.0000 \\
(1.359)\end{array}$ & $\begin{array}{l}0.1667 \\
(0.182)\end{array}$ & $\begin{array}{c}-1.3333^{* * *} \\
(0.297)\end{array}$ & $\begin{array}{c}0.6606^{* *} \\
(0.243)\end{array}$ & $\begin{array}{c}0.7857^{* *} \\
(0.250)\end{array}$ & $\begin{array}{l}0.0148 \\
(0.462)\end{array}$ & $\begin{array}{c}-0.2394 \\
(0.549)\end{array}$ & $\begin{array}{c}-0.8333^{* *} \\
(0.297)\end{array}$ & $\begin{array}{c}-0.5798+ \\
(0.356)\end{array}$ \\
\hline Non-Local * Variable & $\begin{array}{c}-1.0673^{* *} \\
(0.434)\end{array}$ & $\begin{array}{l}1.8421 \\
(1.357)\end{array}$ & $\begin{array}{c}-0.3627 \\
(0.362)\end{array}$ & $\begin{array}{c}-1.5000^{* * * *} \\
(0.227)\end{array}$ & & $\begin{array}{c}1.5000^{* * *} \\
(0.227)\end{array}$ & $\begin{array}{c}-0.0031 \\
(0.602)\end{array}$ & $\begin{array}{c}-0.2562 \\
(0.584)\end{array}$ & $\begin{array}{c}-0.2133 \\
(0.274)\end{array}$ & $\begin{array}{c}-0.3941 \\
(0.591)\end{array}$ \\
\hline Non-Local $*$ Female $*$ Variable & $\begin{array}{c}1.2482^{*} \\
(0.598)\end{array}$ & $\begin{array}{c}-1.6007 \\
(1.415)\end{array}$ & $\begin{array}{c}0.6427^{*} \\
(0.329)\end{array}$ & $\begin{array}{c}2.1190^{* * * *} \\
(0.488)\end{array}$ & & $\begin{array}{c}-2.1190^{* * *} \\
(0.488)\end{array}$ & $\begin{array}{c}-0.3053 \\
(0.371)\end{array}$ & $\begin{array}{l}0.0670 \\
(0.431)\end{array}$ & $\begin{array}{c}0.7133^{*} \\
(0.368)\end{array}$ & $\begin{array}{l}0.9298 \\
(0.648)\end{array}$ \\
\hline Constant & $\begin{array}{c}7.3304^{* * *} \\
(0.049) \\
\end{array}$ & $\begin{array}{c}7.3962^{* * *} \\
(0.063) \\
\end{array}$ & $\begin{array}{c}7.4000^{* * *} \\
(0.074) \\
\end{array}$ & $\begin{array}{c}\text { 7.4074*** } \\
(0.065) \\
\end{array}$ & $\begin{array}{c}7.4074^{* * *} \\
(0.071) \\
\end{array}$ & $\begin{array}{c}7.4074^{* * *} \\
(0.065) \\
\end{array}$ & $\begin{array}{c}7.3417^{* * *} \\
(0.060) \\
\end{array}$ & $\begin{array}{c}7.2931^{* * *} \\
(0.046) \\
\end{array}$ & $\begin{array}{c}7.2222^{* * *} \\
(0.100) \\
\end{array}$ & $\begin{array}{c}7.2453^{* * *} \\
(0.090) \\
\end{array}$ \\
\hline $\begin{array}{l}\text { Observations } \\
R^{2} \\
\text { Number of player }\end{array}$ & $\begin{array}{c}230 \\
0.088 \\
115\end{array}$ & $\begin{array}{c}106 \\
0.253 \\
53\end{array}$ & $\begin{array}{c}110 \\
0.121 \\
55\end{array}$ & $\begin{array}{c}108 \\
0.160 \\
54\end{array}$ & $\begin{array}{c}108 \\
0.104 \\
54\end{array}$ & $\begin{array}{c}108 \\
0.160 \\
54\end{array}$ & $\begin{array}{c}240 \\
0.021 \\
120\end{array}$ & $\begin{array}{c}232 \\
0.035 \\
116\end{array}$ & $\begin{array}{c}108 \\
0.019 \\
54\end{array}$ & $\begin{array}{c}106 \\
0.055 \\
53\end{array}$ \\
\hline $\begin{array}{l}\text { Notes: Robust standard errors } \\
\text { fixed effects included in all spec } \\
\text { As measures of giving and rece } \\
\text { was given to someone in the re } \\
\text { (Columns } 4 \text { to } 6 \text { ). We also use } \\
\text { such help was sporadic, and wh }\end{array}$ & $\begin{array}{l}\text { rentheses } \\
\text { ions. }\end{array}$ & ister ses & $* * * \mathrm{p}<$ & k* $\mathrm{p}<0.05$ & $1,+\mathrm{p}<0.1$ & iit of obser & a player, & $\begin{array}{l}\text { t choice in } \\
\text { ds in the } \\
\text { either vol }\end{array}$ & ame. Referen & $\begin{array}{l}\text { G game. Subje } \\
\text { 1), whether he } \\
\text { or to reciproci } \\
\text { e period, wheth }\end{array}$ \\
\hline
\end{tabular}


Table 5: Interaction with Community involvement and trust

\begin{tabular}{|c|c|c|c|c|c|c|c|c|c|}
\hline Variables interacted: & $\begin{array}{c}\text { (1) } \\
\text { Cooperation (ind) }\end{array}$ & $\begin{array}{c}(2) \\
\text { Cooperation (loc.) }\end{array}$ & $\begin{array}{c}\text { Panel A: D } \\
(3) \\
\text { Organizations } \\
\end{array}$ & $\begin{array}{l}\text { nors } \\
\text { (4) } \\
\text { Celebrations }\end{array}$ & $\begin{array}{c}(5) \\
\text { Trust (1) }\end{array}$ & $\begin{array}{c}(6) \\
\text { Trust (2) }\end{array}$ & $\begin{array}{c}(7) \\
\text { high reward }\end{array}$ & $\begin{array}{c}(8) \\
\text { trust gov }\end{array}$ & $\begin{array}{c}(9) \\
\text { high trust gov }\end{array}$ \\
\hline Non-Local & $\begin{array}{l}0.0769 \\
(0.202)\end{array}$ & $\begin{array}{c}0.1983 \\
(0.128)\end{array}$ & $\begin{array}{c}-0.1130 \\
(0.213)\end{array}$ & $\begin{array}{c}-0.1327 \\
(0.405)\end{array}$ & $\begin{array}{c}-0.1389 \\
(0.138)\end{array}$ & $\begin{array}{l}0.0000 \\
(0.170)\end{array}$ & $\begin{array}{c}-0.1562 \\
(0.115)\end{array}$ & $\begin{array}{l}0.0833 \\
(0.235)\end{array}$ & $\begin{array}{c}-0.1591 \\
(0.116)\end{array}$ \\
\hline Non-Local $*$ Female & $\begin{array}{c}0.3049^{* *} \\
(0.127)\end{array}$ & $\begin{array}{c}0.4569^{* *} \\
(0.165)\end{array}$ & $\begin{array}{c}0.5768^{* * *} \\
(0.138)\end{array}$ & $\begin{array}{l}0.4146 \\
(0.393)\end{array}$ & $\begin{array}{c}0.4861^{* * *} \\
(0.108)\end{array}$ & $\begin{array}{c}0.3871^{* * *} \\
(0.108)\end{array}$ & $\begin{array}{c}0.5199 * * * \\
(0.115)\end{array}$ & $\begin{array}{c}0.1944 \\
(0.162)\end{array}$ & $\begin{array}{c}0.4403^{* * *} \\
(0.077)\end{array}$ \\
\hline Non-Local * Variable & $\begin{array}{c}-0.5315 \\
(0.394)\end{array}$ & $\begin{array}{c}-1.0223^{*} \\
(0.524)\end{array}$ & $\begin{array}{c}-0.0303 \\
(0.071)\end{array}$ & $\begin{array}{c}-0.0128 \\
(0.134)\end{array}$ & $\begin{array}{c}-0.1111 \\
(0.263)\end{array}$ & $\begin{array}{c}-0.2857 \\
(0.217)\end{array}$ & $\begin{array}{c}-0.0313 \\
(0.182)\end{array}$ & $\begin{array}{c}-0.3333+ \\
(0.196)\end{array}$ & $\begin{array}{c}-0.0909 \\
(0.317)\end{array}$ \\
\hline Non-Local $*$ Female $*$ Variable & $\begin{array}{l}0.3877 \\
(0.334)\end{array}$ & $\begin{array}{l}0.0288 \\
(0.605)\end{array}$ & $\begin{array}{r}-0.0217 \\
(0.074)\end{array}$ & $\begin{array}{l}0.0323 \\
(0.153)\end{array}$ & $\begin{array}{l}0.0139 \\
(0.374)\end{array}$ & $\begin{array}{l}0.2097 \\
(0.209)\end{array}$ & $\begin{array}{c}-0.0199 \\
(0.201)\end{array}$ & $\begin{array}{c}0.4240^{*} \\
(0.220)\end{array}$ & $\begin{array}{l}0.5369 \\
(0.367)\end{array}$ \\
\hline Constant & $\begin{array}{c}7.2016^{* * *} \\
(0.043)\end{array}$ & $\begin{array}{c}7.2016^{* * *} \\
(0.042)\end{array}$ & $\begin{array}{c}7.2016^{* * *} \\
(0.047)\end{array}$ & $\begin{array}{c}7.2016^{* * *} \\
(0.048)\end{array}$ & $\begin{array}{c}7.2016^{* * *} \\
(0.049)\end{array}$ & $\begin{array}{c}7.2016^{* * *} \\
(0.046)\end{array}$ & $\begin{array}{c}7.2016^{* * *} \\
(0.048)\end{array}$ & $\begin{array}{c}7.2033^{* * *} \\
(0.048)\end{array}$ & $\begin{array}{c}7.2033^{* * *} \\
(0.048)\end{array}$ \\
\hline $\begin{array}{l}\text { Observations } \\
R^{2} \\
\text { Number of player }\end{array}$ & $\begin{array}{c}248 \\
0.148 \\
124 \\
\end{array}$ & $\begin{array}{c}248 \\
0.129 \\
124 \\
\end{array}$ & $\begin{array}{c}248 \\
0.114 \\
124 \\
\end{array}$ & $\begin{array}{c}248 \\
0.109 \\
124\end{array}$ & $\begin{array}{c}248 \\
0.110 \\
124 \\
\end{array}$ & $\begin{array}{c}248 \\
0.120 \\
124 \\
\end{array}$ & $\begin{array}{c}248 \\
0.109 \\
124 \\
\end{array}$ & $\begin{array}{c}246 \\
0.122 \\
123 \\
\end{array}$ & $\begin{array}{c}246 \\
0.130 \\
123 \\
\end{array}$ \\
\hline Non-Local & $\begin{array}{c}0.1944 \\
(0.330)\end{array}$ & $\begin{array}{l}0.4817 \\
(0.322)\end{array}$ & $\begin{array}{c}-0.1542 \\
(0.336)\end{array}$ & $\begin{array}{l}0.0149 \\
(0.519)\end{array}$ & $\begin{array}{l}0.1951 \\
(0.305)\end{array}$ & $\begin{array}{l}0.2353 \\
(0.738)\end{array}$ & $\begin{array}{l}0.1622 \\
(0.313)\end{array}$ & $\begin{array}{c}-0.8000 \\
(0.582)\end{array}$ & $\begin{array}{l}0.1860 \\
(0.319)\end{array}$ \\
\hline Non-Local * Female & $\begin{array}{l}0.0012 \\
(0.297)\end{array}$ & $\begin{array}{c}-0.1378 \\
(0.369)\end{array}$ & $\begin{array}{l}0.2855 \\
(0.412)\end{array}$ & $\begin{array}{l}0.1287 \\
(0.390)\end{array}$ & $\begin{array}{c}-0.0105 \\
(0.270)\end{array}$ & $\begin{array}{c}-0.0165 \\
(0.670)\end{array}$ & $\begin{array}{l}0.1020 \\
(0.291)\end{array}$ & $\begin{array}{c}1.1684^{*} \\
(0.597)\end{array}$ & $\begin{array}{c}-0.0713 \\
(0.360)\end{array}$ \\
\hline Non-Local * Variable & $\begin{array}{c}-0.0069 \\
(0.259)\end{array}$ & $\begin{array}{c}-0.9594 \\
(1.265)\end{array}$ & $\begin{array}{c}0.1937^{* *} \\
(0.081)\end{array}$ & $\begin{array}{c}0.0628 \\
(0.126)\end{array}$ & $\begin{array}{c}-0.0133 \\
(0.261)\end{array}$ & $\begin{array}{c}-0.0639 \\
(0.710)\end{array}$ & $\begin{array}{l}0.1045 \\
(0.217)\end{array}$ & $\begin{array}{c}1.2286^{*} \\
(0.639)\end{array}$ & $\begin{array}{c}0.0362 \\
(0.343)\end{array}$ \\
\hline Non-Local $*$ Female $*$ Variable & $\begin{array}{c}-0.2342 \\
(0.198)\end{array}$ & $\begin{array}{l}0.3244 \\
(1.188)\end{array}$ & $\begin{array}{c}-0.2002+ \\
(0.113)\end{array}$ & $\begin{array}{c}-0.0719 \\
(0.146)\end{array}$ & $\begin{array}{c}-1.5046 \\
(1.573)\end{array}$ & $\begin{array}{c}-0.1271 \\
(0.504)\end{array}$ & $\begin{array}{c}-0.7687^{* *} \\
(0.252)\end{array}$ & $\begin{array}{c}-1.5766^{*} \\
(0.709)\end{array}$ & $\begin{array}{c}-0.0081 \\
(0.387)\end{array}$ \\
\hline Constant & $\begin{array}{c}7.3417^{* * *} \\
(0.060)\end{array}$ & $\begin{array}{c}7.3417^{* * *} \\
(0.056)\end{array}$ & $\begin{array}{c}7.3417^{* * *} \\
(0.055)\end{array}$ & $\begin{array}{c}7.3417^{* * *} * \\
(0.058)\end{array}$ & $\begin{array}{c}7.3417^{* * *} \\
(0.062)\end{array}$ & $\begin{array}{c}7.3417^{* * *} \\
(0.059)\end{array}$ & $\begin{array}{c}7.3417^{* * *} \\
(0.057)\end{array}$ & $\begin{array}{c}7.3417^{* * *} \\
(0.044)\end{array}$ & $\begin{array}{c}7.3417^{* * *} \\
(0.059)\end{array}$ \\
\hline $\begin{array}{l}\text { Observations } \\
R^{2} \\
\text { Number of player }\end{array}$ & $\begin{array}{c}240 \\
0.019 \\
120\end{array}$ & $\begin{array}{c}240 \\
0.021 \\
120\end{array}$ & $\begin{array}{c}240 \\
0.033 \\
120\end{array}$ & $\begin{array}{c}240 \\
0.016 \\
120\end{array}$ & $\begin{array}{c}240 \\
0.047 \\
120\end{array}$ & $\begin{array}{c}240 \\
0.018 \\
120\end{array}$ & $\begin{array}{c}240 \\
0.041 \\
120\end{array}$ & $\begin{array}{c}240 \\
0.084 \\
120\end{array}$ & $\begin{array}{c}240 \\
0.014 \\
120\end{array}$ \\
\hline $\begin{array}{l}\text { Notes: Robust standard errors i } \\
\text { LPG game. Subject fixed effects } \\
\text { As measures of community invol } \\
\text { time (Column 1), the share of re } \\
\text { (social, political, religious) (Colu } \\
\text { trust most people, (ii) most peo } \\
\text { confidence that the government }\end{array}$ & $\begin{array}{l}\text { rentheses, cluster } \\
\text { uded in all specifi } \\
\text { ent and trust, we } \\
\text { dents in her local } \\
\text { 3), the number o } \\
\text { would treat her } \mathrm{f} \\
\text { adequately spend }\end{array}$ & $\begin{array}{l}\text { sion. }{ }^{* * *} \mathrm{p}<0.01 \\
\text { ons. } \\
\text { a dummy for wl } \\
\text { who also think } \mathrm{s} \\
\text { mmunity celebra } \\
\text { (iii) effort is } \mathrm{r} \\
\text { revenues, and } \mathrm{fc}\end{array}$ & $\begin{array}{l}\mathrm{p}<0.05,{ }^{*} \mathrm{f} \\
\text { er the respor } \\
\text { olumn } 2 \text {, th } \\
\mathrm{s} \text { in which } \mathrm{s} \\
\text { ded with hi } \\
\text { aether she } \mathrm{h}\end{array}$ & $\begin{array}{l}1,+\mathrm{p}<0 . \\
\mathrm{t} \text { believes } \\
\text { imber of } \mathrm{o} \\
\text { articipates } \\
\text { income } \mathrm{m} \\
\text { gh confide }\end{array}$ & $\begin{array}{l}\text { Unit of ob } \\
\text { people in } \\
\text { izations in } \\
\text { olumn } 4 \text { ); } \\
\text { of the tim }\end{array}$ & $\begin{array}{l}\text { vation i } \\
\text { locality } \\
\text { hich the } \\
\text { mmies } \mathrm{f} \\
\text { Column }\end{array}$ & $\begin{array}{l}\text { layer's eff } \\
\text { erate to } \\
\text { ondent pa } \\
\text { ether the } \\
\text { o } 7 \text { ); dum } \\
\text { ns } 8 \text { and }\end{array}$ & $\begin{array}{l}\text { hoice in } \\
\text { their pr } \\
\text { pated in } \\
\text { ondent } \\
\text { for wh }\end{array}$ & $\begin{array}{l}\text { me. Reference } \\
\text { last } 12 \text { months } \\
\text { ves (i) she can } \\
\text { she has some }\end{array}$ \\
\hline
\end{tabular}


Table 6: Knowledge of other participants and neighboring health center

\begin{tabular}{|c|c|c|c|c|c|c|}
\hline Variables interacted: & $\begin{array}{c}(1) \\
\text { Know (all) }\end{array}$ & $\begin{array}{c}(2) \\
\text { Know (family) }\end{array}$ & $\begin{array}{c}\text { Panel A: Donors } \\
\text { (3) } \\
\text { Know (activities) }\end{array}$ & $\begin{array}{l}(4) \\
\text { Other loc. know }\end{array}$ & $\begin{array}{c}(5) \\
\text { Other loc. visit }\end{array}$ & $\begin{array}{c}(6) \\
\text { Other loc. clinic } \\
\end{array}$ \\
\hline Non-Local & $\begin{array}{c}-1.0000 \\
(0.843)\end{array}$ & $\begin{array}{c}-0.1707+ \\
(0.091)\end{array}$ & $\begin{array}{c}-0.1750+ \\
(0.094)\end{array}$ & $\begin{array}{c}-0.2400 \\
(0.186)\end{array}$ & $\begin{array}{c}-0.1613 \\
(0.164)\end{array}$ & $\begin{array}{c}-0.1579 \\
(0.123)\end{array}$ \\
\hline Non-Local * Female & $\begin{array}{c}1.4545+ \\
(0.858)\end{array}$ & $\begin{array}{c}0.4991^{* * *} \\
(0.076)\end{array}$ & $\begin{array}{c}0.4801^{* * *} \\
(0.101)\end{array}$ & $\begin{array}{c}0.6289^{* *} \\
(0.189)\end{array}$ & $\begin{array}{c}0.5613^{* * *} \\
(0.126)\end{array}$ & $\begin{array}{c}0.5304^{* * *} \\
(0.078)\end{array}$ \\
\hline Non-Local * Variable & $\begin{array}{l}0.9524 \\
(0.963)\end{array}$ & $\begin{array}{c}0.1707+ \\
(0.091)\end{array}$ & $\begin{array}{l}0.0500 \\
(0.079)\end{array}$ & $\begin{array}{l}0.1530 \\
(0.264)\end{array}$ & $\begin{array}{c}-0.0152 \\
(0.257)\end{array}$ & $\begin{array}{c}-0.0421 \\
(0.238)\end{array}$ \\
\hline Non-Local * Female * Variable & $\begin{array}{c}-1.0838 \\
(0.925)\end{array}$ & $\begin{array}{c}-0.0546 \\
(0.300)\end{array}$ & $\begin{array}{l}0.1449 \\
(0.208)\end{array}$ & $\begin{array}{c}-0.2419 \\
(0.289)\end{array}$ & $\begin{array}{c}-0.1268 \\
(0.299)\end{array}$ & $\begin{array}{c}-0.0504 \\
(0.274)\end{array}$ \\
\hline Constant & $\begin{array}{c}7.2016^{* * *} \\
(0.049)\end{array}$ & $\begin{array}{c}7.1789^{* * *} \\
(0.045)\end{array}$ & $\begin{array}{c}7.1789^{* * *} \\
(0.051)\end{array}$ & $\begin{array}{c}7.2016^{* * *} \\
(0.047)\end{array}$ & $\begin{array}{c}7.2016^{* * *} \\
(0.048)\end{array}$ & $\begin{array}{c}7.2016^{* * *} \\
(0.047)\end{array}$ \\
\hline $\begin{array}{l}\text { Observations } \\
R^{2} \\
\text { Number of player }\end{array}$ & $\begin{array}{c}248 \\
0.161 \\
124 \\
\end{array}$ & $\begin{array}{c}246 \\
0.110 \\
123 \\
\end{array}$ & $\begin{array}{c}246 \\
0.115 \\
123 \\
\end{array}$ & $\begin{array}{c}248 \\
0.113 \\
124 \\
\end{array}$ & $\begin{array}{c}248 \\
0.113 \\
124 \\
\end{array}$ & $\begin{array}{c}248 \\
0.110 \\
124 \\
\end{array}$ \\
\hline Variables interacted: & $\begin{array}{c}(1) \\
\text { Know (all) }\end{array}$ & $\begin{array}{c}(2) \quad \mathrm{P} \\
\text { Know (family) }\end{array}$ & $\begin{array}{c}\text { anel B: Recipients } \\
\text { (3) } \\
\text { Know (activities) }\end{array}$ & $\begin{array}{c}\quad(4) \\
\text { Other loc. know }\end{array}$ & $\begin{array}{c}(5) \\
\text { Other loc. visit }\end{array}$ & $\begin{array}{c}\quad(6) \\
\text { Other loc. clinic }\end{array}$ \\
\hline Non-Local & $\begin{array}{l}1.8333 \\
(1.233)\end{array}$ & $\begin{array}{l}0.1628 \\
(0.278)\end{array}$ & $\begin{array}{l}0.0952 \\
(0.285)\end{array}$ & $\begin{array}{c}0.1111 \\
(0.110)\end{array}$ & $\begin{array}{c}0.1935^{* *} \\
(0.076)\end{array}$ & $\begin{array}{c}0.2222^{* *} \\
(0.076)\end{array}$ \\
\hline Non-Local * Female & $\begin{array}{l}-1.5833 \\
(1.257)\end{array}$ & $\begin{array}{c}-0.0378 \\
(0.329)\end{array}$ & $\begin{array}{l}0.1293 \\
(0.378)\end{array}$ & $\begin{array}{l}0.0317 \\
(0.200)\end{array}$ & $\begin{array}{c}-0.0196 \\
(0.169)\end{array}$ & $\begin{array}{c}-0.0622 \\
(0.153)\end{array}$ \\
\hline Non-Local * Variable & $\begin{array}{c}-1.8551 \\
(1.247)\end{array}$ & $\begin{array}{l}0.2122 \\
(0.237)\end{array}$ & $\begin{array}{l}0.5714 \\
(0.414)\end{array}$ & $\begin{array}{l}0.1689 \\
(0.564)\end{array}$ & $\begin{array}{c}-0.0031 \\
(0.609)\end{array}$ & $\begin{array}{c}-0.0972 \\
(0.736)\end{array}$ \\
\hline Non-Local $*$ Female $*$ Variable & $\begin{array}{l}1.7051 \\
(1.206)\end{array}$ & $\begin{array}{l}-0.2539 \\
(0.308)\end{array}$ & $\begin{array}{c}-0.9538+ \\
(0.550)\end{array}$ & $\begin{array}{c}-0.2208 \\
(0.435)\end{array}$ & $\begin{array}{c}-0.1708 \\
(0.482)\end{array}$ & $\begin{array}{c}-0.0628 \\
(0.715)\end{array}$ \\
\hline Constant & $\begin{array}{c}7.3417^{* * *} \\
(0.056)\end{array}$ & $\begin{array}{c}7.3193^{* * *} \\
(0.058)\end{array}$ & $\begin{array}{c}7.3361^{* * *} \\
(0.054)\end{array}$ & $\begin{array}{c}7.3417^{* * * *} \\
(0.058)\end{array}$ & $\begin{array}{c}7.3417^{* * *} \\
(0.055)\end{array}$ & $\begin{array}{c}7.3417^{* * * *} \\
(0.058)\end{array}$ \\
\hline $\begin{array}{l}\text { Observations } \\
R^{2} \\
\text { Number of player }\end{array}$ & $\begin{array}{c}240 \\
0.106 \\
120\end{array}$ & $\begin{array}{c}238 \\
0.016 \\
119\end{array}$ & $\begin{array}{c}238 \\
0.037 \\
119\end{array}$ & $\begin{array}{c}240 \\
0.016 \\
120\end{array}$ & $\begin{array}{c}240 \\
0.017 \\
120\end{array}$ & $\begin{array}{c}240 \\
0.017 \\
120\end{array}$ \\
\hline $\begin{array}{l}\text { Notes: Robust standard errors } \\
\text { effort choice in a game. Referen } \\
\text { We consider the following varial } \\
\text { of the other participants in the } \\
\text { with half or more of them (Col } \\
\text { whether she knows the other lo } \\
\text { matched locality (Columns } 4 \text { to }\end{array}$ & $\begin{array}{l}\text { arentheses } \\
\text { PG game. } \\
\text { as proxies } \\
\text { on, whethe } \\
1 \text { to } 3) \text {. C } \\
\text {, whether }\end{array}$ & $\begin{array}{l}\text { ister session } \\
\text { ject fixed ef } \\
\text { the participa } \\
\text { lf or more o } \\
\text { proxies for t }\end{array}$ & $\begin{array}{l}* \mathrm{p}<0.01,{ }^{* *} \mathrm{p} \\
\text { included in all } \\
\text { network in her } \\
\text { session particip } \\
\text { trength of the p } \\
\text { ther locality anc }\end{array}$ & $\begin{array}{l}5,{ }^{*} \mathrm{p}<0.1,+ \\
\text { cifications. } \\
\text { locality: whetl } \\
\text { s belong to her } \\
\text { cipant's networl } \\
\text { c whether she h }\end{array}$ & $\begin{array}{l}\text {.15. Unit of } 0 \\
\text { the participant } \\
\text { iily, whether sh } \\
\text { the matched l } \\
\text { ctually been in }\end{array}$ & $\begin{array}{l}\text { vation is a player's } \\
\text { ws almost all or all } \\
\text { ares daily activities } \\
\text { ity are dummies for } \\
\text { health clinic of the }\end{array}$ \\
\hline
\end{tabular}

Table 7: Individual socio-economic characteristics

\begin{tabular}{|c|c|c|c|c|c|c|c|c|c|c|c|c|}
\hline Variables interacted: & $\begin{array}{l}(1) \\
\text { age }\end{array}$ & $\begin{array}{c}(2) \\
\text { education }\end{array}$ & $\begin{array}{c}(3) \\
\text { married }\end{array}$ & $\begin{array}{c}(4) \\
\text { born mun }\end{array}$ & $\begin{array}{c}(5) \\
\text { siblings }\end{array}$ & $\begin{array}{c}\begin{array}{c}\text { Panel } \\
(6) \\
\text { children }\end{array} \\
\end{array}$ & $\begin{array}{c}\text { A: Donors } \\
(7) \\
\text { Oportunidades } \\
\end{array}$ & $\begin{array}{l}(8) \\
\text { Elderly pension }\end{array}$ & $\begin{array}{c}(9) \\
\text { Procampo } \\
\end{array}$ & $\begin{array}{c}(10) \\
\text { Count programs }\end{array}$ & $\begin{array}{c}(11) \\
\text { lowest } 25 \text { asset }\end{array}$ & $\begin{array}{c}(12) \\
\text { highest 25 asset }\end{array}$ \\
\hline Non-Local & $\begin{array}{c}-0.6187 \\
(0.827)\end{array}$ & $\begin{array}{l}0.0500 \\
(0.177)\end{array}$ & $\begin{array}{c}-0.2308 \\
(0.441)\end{array}$ & $\begin{array}{c}0.0000 \\
(0.240)\end{array}$ & $\begin{array}{c}-1.0558 \\
(0.738)\end{array}$ & $\begin{array}{c}-0.3563 \\
(0.276)\end{array}$ & $\begin{array}{c}-0.1000 \\
(0.173)\end{array}$ & $\begin{array}{c}-0.1628+ \\
(0.087)\end{array}$ & $\begin{array}{c}-0.2000 \\
(0.149)\end{array}$ & $\begin{array}{c}-0.4599^{* * *} \\
(0.141)\end{array}$ & $\begin{array}{c}-0.1389^{*} \\
(0.067)\end{array}$ & $\begin{array}{c}-0.2000^{* * *} \\
(0.080)\end{array}$ \\
\hline Non-Local * Female & $\begin{array}{l}0.9268 \\
(0.889)\end{array}$ & $\begin{array}{c}0.3000^{*} \\
(0.146)\end{array}$ & $\begin{array}{c}0.6808+ \\
(0.397)\end{array}$ & $\begin{array}{c}0.4091 * * \\
(0.166)\end{array}$ & $\begin{array}{l}1.1589 \\
(0.769)\end{array}$ & $\begin{array}{c}0.6955 * * \\
(0.276)\end{array}$ & $\begin{array}{l}0.1000 \\
(0.173)\end{array}$ & $\begin{array}{c}0.5128^{* * *} \\
(0.100)\end{array}$ & $\begin{array}{c}0.7312^{* * *} \\
(0.085)\end{array}$ & $\begin{array}{c}0.9667^{* * *} \\
(0.168)\end{array}$ & $\begin{array}{c}0.4722 * * \\
(0.137)\end{array}$ & $\begin{array}{c}0.5898^{* * * *} \\
(0.101)\end{array}$ \\
\hline Non-Local * Variable & $\begin{array}{c}0.0129 \\
(0.023)\end{array}$ & $\begin{array}{c}-0.3714 \\
(0.281)\end{array}$ & $\begin{array}{l}0.0879 \\
(0.583)\end{array}$ & $\begin{array}{c}-0.2162 \\
(0.305)\end{array}$ & $\begin{array}{l}0.1492 \\
(0.119)\end{array}$ & $\begin{array}{l}0.0695 \\
(0.082)\end{array}$ & $\begin{array}{c}-0.0842 \\
(0.152)\end{array}$ & $\begin{array}{c}-0.0372 \\
(0.135)\end{array}$ & $\begin{array}{l}0.0571 \\
(0.143)\end{array}$ & $\begin{array}{c}0.1362^{* *} \\
(0.041)\end{array}$ & $\begin{array}{c}-0.1111 \\
(0.226)\end{array}$ & $\begin{array}{l}0.1231 \\
(0.147)\end{array}$ \\
\hline Non-Local * Female * Variable & $\begin{array}{l}-0.0120 \\
(0.024)\end{array}$ & $\begin{array}{c}0.3339 \\
(0.302)\end{array}$ & $\begin{array}{c}-0.2343 \\
(0.525)\end{array}$ & $\begin{array}{l}0.1219 \\
(0.213)\end{array}$ & $\begin{array}{c}-0.1088 \\
(0.118)\end{array}$ & $\begin{array}{c}-0.0688 \\
(0.083)\end{array}$ & $\begin{array}{c}0.4556^{*} \\
(0.224)\end{array}$ & $\begin{array}{c}-0.0003 \\
(0.268)\end{array}$ & $\begin{array}{c}-0.3838^{* *} \\
(0.115)\end{array}$ & $\begin{array}{c}-0.2028^{* *} \\
(0.068)\end{array}$ & $\begin{array}{l}0.1462 \\
(0.375)\end{array}$ & $\begin{array}{c}-0.3364 \\
(0.215)\end{array}$ \\
\hline Constant & $\begin{array}{c}7.2016^{* * * *} \\
(0.049)\end{array}$ & $\begin{array}{c}7.2016^{* * *} \\
(0.049) \\
\end{array}$ & $\begin{array}{c}7.2016 * * * \\
(0.048)\end{array}$ & $\begin{array}{c}7.2016^{* * *} \\
(0.046) \\
\end{array}$ & $\begin{array}{c}7.2016 * 6 * * \\
(0.043) \\
\end{array}$ & $\begin{array}{c}7.2016 * * * \\
(0.047)\end{array}$ & $\begin{array}{c}7.2016^{* * *} \\
(0.047) \\
\end{array}$ & $\begin{array}{c}7.2016^{* * *} \\
(0.047) \\
\end{array}$ & $\begin{array}{c}7.2016^{* * *} \\
(0.048) \\
\end{array}$ & $\begin{array}{c}7.2016^{* * *} \\
(0.047) \\
\end{array}$ & $\begin{array}{c}7.2016 * * * \\
(0.047) \\
\end{array}$ & $\begin{array}{c}7.2016^{* * * *} \\
(0.048) \\
\end{array}$ \\
\hline Observations & 248 & 248 & 248 & 248 & 248 & 248 & 248 & 248 & 248 & 248 & 248 & 248 \\
\hline & 0.120 & 0.126 & 0.113 & 0.115 & 0.188 & 0.127 & 0.118 & 0.109 & 0.130 & 0.133 & 0.110 & 0.117 \\
\hline Number of player & 124 & 124 & 124 & 124 & 124 & 124 & 124 & 124 & 124 & 124 & 124 & 124 \\
\hline Variables interacted: & $\begin{array}{l}(1) \\
\text { age }\end{array}$ & $\begin{array}{c}(2) \\
\text { education }\end{array}$ & $\begin{array}{c}(3) \\
\text { married }\end{array}$ & $\begin{array}{c}(4) \\
\text { born mun }\end{array}$ & $\begin{array}{c}(5) \\
\text { siblings }\end{array}$ & $\begin{array}{l}\begin{array}{l}\text { Panel } \mathrm{B} \\
(6) \\
\text { children }\end{array} \\
\end{array}$ & $\begin{array}{l}\text { : Recipients } \\
(7) \\
\text { Oportunidades }\end{array}$ & $\begin{array}{c}(8) \\
\text { Elderly pension }\end{array}$ & $\begin{array}{c}(9) \\
\text { Procampo } \\
\end{array}$ & $\begin{array}{c}(10) \\
\text { Count programs }\end{array}$ & $\begin{array}{c}(11) \\
\text { lowest } 25 \text { asset }\end{array}$ & $\begin{array}{c}(12) \\
\text { highest } 25 \text { asset }\end{array}$ \\
\hline Non-Local & $\begin{array}{c}-0.5252 \\
(0.360)\end{array}$ & $\begin{array}{c}0.4688 \\
(0.363)\end{array}$ & $\begin{array}{c}-0.3158 \\
(0.346)\end{array}$ & $\begin{array}{c}-0.4167 \\
(0.509)\end{array}$ & $\begin{array}{l}-0.2609 \\
(0.314)\end{array}$ & $\begin{array}{l}0.2111 \\
(0.422)\end{array}$ & $\begin{array}{c}0.2500 \\
(0.165)\end{array}$ & $\begin{array}{l}0.3684 \\
(0.385)\end{array}$ & $\begin{array}{c}-0.0714 \\
(0.109)\end{array}$ & $\begin{array}{l}0.0639 \\
(0.356)\end{array}$ & $\begin{array}{c}0.0000 \\
(0.239)\end{array}$ & $\begin{array}{l}0.2000 \\
(0.381)\end{array}$ \\
\hline Non-Local * Female & $\begin{array}{l}0.5324 \\
(0.508)\end{array}$ & $\begin{array}{c}-0.3818 \\
(0.363)\end{array}$ & $\begin{array}{l}0.3158 \\
(0.312)\end{array}$ & $\begin{array}{r}0.4667 \\
(0.481)\end{array}$ & $\begin{array}{c}0.3102 \\
(0.360)\end{array}$ & $\begin{array}{l}0.0822 \\
(0.477)\end{array}$ & $\begin{array}{c}-0.2500 \\
(0.163)\end{array}$ & $\begin{array}{c}-0.2498 \\
(0.429)\end{array}$ & $\begin{array}{l}0.1914 \\
(0.365)\end{array}$ & $\begin{array}{l}0.0923 \\
(0.519)\end{array}$ & $\begin{array}{c}0.1250 \\
(0.226)\end{array}$ & $\begin{array}{c}-0.0750 \\
(0.463)\end{array}$ \\
\hline Non-Local * Variable & $\begin{array}{c}0.0166^{*} \\
(0.009)\end{array}$ & $\begin{array}{l}-0.7188 \\
(0.471)\end{array}$ & $\begin{array}{c}0.8006 \\
(0.630\rangle\end{array}$ & $\begin{array}{c}0.7917 \\
(0.658)\end{array}$ & $\begin{array}{c}0.1003 \\
(0.104)\end{array}$ & $\begin{array}{c}-0.0058 \\
(0.051)\end{array}$ & $\begin{array}{l}-0.0682 \\
(0.195)\end{array}$ & $\begin{array}{c}-0.6541 \\
(0.463)\end{array}$ & $\begin{array}{c}0.3609 \\
(0.257)\end{array}$ & $\begin{array}{l}0.0439 \\
(0.043)\end{array}$ & $\begin{array}{l}0.5882 \\
(0.588)\end{array}$ & $\begin{array}{c}-0.0333 \\
(0.536)\end{array}$ \\
\hline Non-Local * Female * Variable & $\begin{array}{c}-0.0136 \\
(0.011)\end{array}$ & $\begin{array}{c}0.81366^{*} \\
(0.362)\end{array}$ & $\begin{array}{c}-0.6603 \\
(0.719)\end{array}$ & $\begin{array}{c}-0.6958 \\
(0.759)\end{array}$ & $\begin{array}{c}-0.0881 \\
(0.091)\end{array}$ & $\begin{array}{c}-0.0439 \\
(0.058)\end{array}$ & $\begin{array}{l}0.2085 \\
(0.352)\end{array}$ & $\begin{array}{l}0.6466 \\
(0.547)\end{array}$ & $\begin{array}{c}-0.3646 \\
(0.321)\end{array}$ & $\begin{array}{c}-0.0596 \\
(0.109)\end{array}$ & $\begin{array}{c}-0.6299 \\
(0.537)\end{array}$ & $\begin{array}{l}0.0083 \\
(0.722)\end{array}$ \\
\hline Constant & $\begin{array}{c}\begin{array}{c}7.3417^{* * * *} \\
(0.058)\end{array} \\
\end{array}$ & $\begin{array}{c}7.3417^{* * *} \\
(0.054) \\
\end{array}$ & $\begin{array}{c}\begin{array}{c}7.3417^{* * * *} \\
(0.052)\end{array} \\
\end{array}$ & $\begin{array}{c}7.3417^{* * *} \\
(0.059)\end{array}$ & $\begin{array}{c}7.3417^{* * *} \\
(0.055) \\
\end{array}$ & $\begin{array}{c}\begin{array}{c}7.3417^{* * *} \\
(0.058)\end{array} \\
\end{array}$ & $\begin{array}{c}7.3417^{* * *} \\
(0.059) \\
\end{array}$ & $\begin{array}{c}7.3417^{* * *} \\
(0.062) \\
\end{array}$ & $\begin{array}{c}7.3417^{* * *} \\
(0.056)\end{array}$ & $\begin{array}{c}7.3417^{* * *} \\
(0.057)\end{array}$ & $\begin{array}{c}7.3417^{* * * *} \\
(0.061) \\
\end{array}$ & $\begin{array}{c}7.3417^{* * *} \\
(0.060) \\
\end{array}$ \\
\hline Observations & 240 & 240 & 240 & 240 & 240 & 240 & 240 & 240 & 240 & 240 & 240 & 240 \\
\hline & $\begin{array}{c}0.035 \\
120\end{array}$ & 0.047 & 0.054 & 0.044 & 0.035 & 0.020 & 0.015 & 0.036 & 0.021 & 0.016 & 0.034 & 0.014 \\
\hline $\begin{array}{l}\text { Number of player } \\
\text { Notes: Robust standard errors i }\end{array}$ & $\begin{array}{l}120 \\
\text { arentheses. }\end{array}$ & $\frac{120}{\text { cluster se }}$ & $\frac{120}{\text { ion. }{ }^{* * *} \mathrm{p}}$ & $\frac{120}{1,{ }^{* *} \mathrm{p}<0 .}$ & $\frac{120}{05,{ }^{*} \mathrm{p}<0.1,}$ & $\begin{array}{c}120 \\
+\mathrm{p}<0.15 .\end{array}$ & $\frac{120}{\text { it of observ }}$ & $\frac{120}{\text { s a player's effc }}$ & $\frac{120}{\text { rt choice in a }}$ & $\begin{array}{l}120 \\
\text { game. Reference }\end{array}$ & $\frac{120}{{ }^{\circ} \text { G game. Sul }}$ & $\frac{120}{\text { xed effects included }}$ \\
\hline
\end{tabular}


Table 8: Heterogeneous effects - Differences between session and matched localities

\begin{tabular}{|c|c|c|c|c|c|c|c|c|c|}
\hline $\begin{array}{l}\text { Panel A: Donors } \\
\text { Variable interacted: Ratio Var matched/ Var session }\end{array}$ & $\begin{array}{c}(1) \\
\text { Total pop }\end{array}$ & $\begin{array}{c}(2) \\
\text { Share catholics }\end{array}$ & $\begin{array}{c}(3) \\
\text { Avg farm size }\end{array}$ & $\begin{array}{c}(4) \\
\text { Share PC benef }\end{array}$ & $\begin{array}{c}(5) \\
\text { KM to major city }\end{array}$ & $\begin{array}{c}(6) \\
\text { Mins to major city }\end{array}$ & $\begin{array}{c}(7) \\
\text { KM bet. locs }\end{array}$ & $\begin{array}{c}(8) \\
\text { Mins bet. locs }\end{array}$ & $\begin{array}{c}9) \\
\begin{array}{c}\text { Common use land } \\
\text { (dummies) }\end{array}\end{array}$ \\
\hline Non-Local & $\begin{array}{l}-0.353 \\
{[0.258]}\end{array}$ & $\begin{array}{l}-0.210 \\
{[0.199]}\end{array}$ & $\begin{array}{l}-0.385 \\
{[0.275]}\end{array}$ & $\begin{array}{l}-0.166 \\
{[0.115]}\end{array}$ & $\begin{array}{l}0.057^{*} \\
{[0.025]}\end{array}$ & $\begin{array}{c}0.013 \\
{[0.018]}\end{array}$ & $\begin{array}{l}-0.207 \\
{[0.128]}\end{array}$ & $\begin{array}{l}-0.218 \\
{[0.134]}\end{array}$ & $\begin{array}{l}-0.107 * * \\
{[0.034]}\end{array}$ \\
\hline Non-Local * female & $\begin{array}{l}0.611^{* * *} \\
{[0.152}\end{array}$ & $0.563^{* * *}$ & $0.464^{* * *}$ & $0.520^{* * * *}$ & $0.440^{* * *}$ & $0.488^{* * *}$ & $0.344^{*}$ & $0.363^{*}$ & $0.474^{* * *}$ \\
\hline Non-Local * Variable & $\begin{array}{l}{[0.152]} \\
0.109 \\
0\end{array}$ & 0.033 & 0.230 & -0.000 & $-0.324^{* * *}$ & $-0.141^{* * *}$ & 0.001 & 0.001 & \\
\hline Non-Local $*$ female $*$ Variable & $\begin{array}{l}{[0.111]} \\
-0.051 \\
{[0.135]}\end{array}$ & $\begin{array}{l}-0.0840 \\
-0.040 \\
{[0.036]}\end{array}$ & $\begin{array}{c}{[0.211]} \\
0.043 \\
{[0.140]}\end{array}$ & $\begin{array}{r}-0.0003 \\
-0.003 \\
{[0.004]}\end{array}$ & $\begin{array}{c}{[0.0027} \\
0.027 \\
{[0.077]}\end{array}$ & $\begin{array}{r}{[-0.045]} \\
-0.045 \\
{[0.038]}\end{array}$ & $\left.\begin{array}{c}0.005 \\
{[0.003]}\end{array}\right]$ & $\left.\begin{array}{c}0.003 \\
0.003]\end{array}\right]$ & \\
\hline Non-Local * CU land LL & & & & & & & & & $\begin{array}{l}0.107^{* *} \\
{[0.034]}\end{array}$ \\
\hline Non-Local * female * ${ }^{*} \mathrm{CU}$ land LL & & & & & & & & & $\begin{array}{l}-0.202^{*} \\
{[0.095]}\end{array}$ \\
\hline Non-Local * CU land LH & & & & & & & & & $\begin{array}{l}0.107^{* *} \\
{[0.034]}\end{array}$ \\
\hline Non-Local * female *CU land LH & & & & & & & & & $\begin{array}{l}0.226^{* *} \\
{[0.095]}\end{array}$ \\
\hline Non-Local $* \mathrm{CU}$ land $\mathrm{HL}$ & & & & & & & & & $\begin{array}{c}-0.607 * * * \\
{[0.034]}\end{array}$ \\
\hline Non-Local * female *CU land $\mathrm{HL}$ & & & & & & & & & $\begin{array}{l}-0.094 \\
{[0.095]}\end{array}$ \\
\hline Constant & $\begin{array}{c}7.202^{* * *} \\
{[0.046]}\end{array}$ & $\begin{array}{c}7.202^{* * *} \\
{[0.048]}\end{array}$ & $\begin{array}{c}7.202^{* * *} \\
{[0.042]}\end{array}$ & $\begin{array}{c}7.202^{* * *} \\
{[0.047]}\end{array}$ & $\begin{array}{c}7.202^{* * *} \\
{[0.030]}\end{array}$ & $\begin{array}{c}7.202^{* * *} \\
{[0.019]}\end{array}$ & $\begin{array}{c}7.202^{* * *} \\
{[0.045]}\end{array}$ & $\begin{array}{c}7.202^{* * *} \\
{[0.046]}\end{array}$ & $\begin{array}{c}7.202^{* * * *} \\
{[0.024]}\end{array}$ \\
\hline $\mathrm{N}$ & 248 & 248 & 248 & 248 & 248 & 248 & 248 & 248 & 248 \\
\hline R-sq & 0.116 & 0.109 & 0.131 & 0.109 & 0.162 & 0.185 & 0.123 & 0.119 & 0.180 \\
\hline $\begin{array}{l}\text { Panel B: Recipients } \\
\text { Variable interacted: Ratio Var matched/ Var session }\end{array}$ & $\begin{array}{c}\text { (1) } \\
\text { Total pop }\end{array}$ & $\begin{array}{c}(2) \\
\text { Share catholics }\end{array}$ & $\begin{array}{c}(3) \\
\text { Avg farm size }\end{array}$ & $\begin{array}{c}(4) \\
\text { Share PC benef }\end{array}$ & $\begin{array}{c}\text { (5) } \\
\text { KM to major city }\end{array}$ & $\begin{array}{c}(6) \\
\text { Mins to major city }\end{array}$ & $\begin{array}{c}\text { (7) } \\
\text { KM bet. locs }\end{array}$ & $\begin{array}{c}(8) \\
\text { Mins bet. locs }\end{array}$ & $\begin{array}{c}(9) \\
\begin{array}{c}\text { Common use land } \\
\text { (dummies) }\end{array}\end{array}$ \\
\hline Non-Local & $\begin{array}{l}-0.163 \\
{[0.249]}\end{array}$ & $\begin{array}{l}0.645 \\
{[0.379]}\end{array}$ & $\begin{array}{c}0.004 \\
{[0.461]}\end{array}$ & $\begin{array}{l}0.382 \\
{[0.249]}\end{array}$ & $\begin{array}{c}0.452 \\
{[0.317]}\end{array}$ & $\begin{array}{c}0.356 \\
{[0.309]}\end{array}$ & $\begin{array}{l}-0.354 \\
{[0.330]}\end{array}$ & $\begin{array}{l}-0.349 \\
{[0.389]}\end{array}$ & $\begin{array}{c}1.43 \mathrm{e}-16 \\
{[0.267]}\end{array}$ \\
\hline Non-Local $*$ female & 0.271 & $\begin{array}{r}-0.449 \\
{[0.528}\end{array}$ & $\begin{array}{l}-0.142 \\
{[0.551]}\end{array}$ & $\begin{array}{r}-0.213 \\
{[0.332]}\end{array}$ & $\begin{array}{r}-0.413 \\
{[0.390]}\end{array}$ & $\left.\begin{array}{r}-0.294 \\
{[0.373]}\end{array}\right]$ & $\begin{array}{l}0.709 \\
{[0.419]}\end{array}$ & $\begin{array}{l}0.809 \\
{[0.481]}\end{array}$ & $\begin{array}{l}0.205 \\
0.168\end{array}$ \\
\hline $\begin{array}{l}\text { Non-Local * Variable } \\
\text { Non-Local * female * Variable }\end{array}$ & $\begin{array}{l}0.276 \\
{[0.192]} \\
-0.270\end{array}$ & $\begin{array}{r}-0.389^{*} \\
{[0.170]} \\
0.341\end{array}$ & $\begin{array}{c}0.190 \\
{[0.238]} \\
0.090\end{array}$ & $\begin{array}{c}-0.063^{* * *} \\
{[0.010]} \\
0.052^{* * *}\end{array}$ & $\begin{array}{l}-0.366^{*} \\
{[0.182]} \\
0.499^{*}\end{array}$ & $\begin{array}{l}-0.136^{*} \\
{[0.069]} \\
0.190^{*}\end{array}$ & $\begin{array}{l}0.014 \\
{[0.009]} \\
-0.020\end{array}$ & $\begin{array}{c}0.012 \\
{[0.010]} \\
-0.020\end{array}$ & \\
\hline Non-Local * CU land LL & {$[0.255]$} & {$[0.204]$} & {$[0.300]$} & {$[0.014]$} & {$[0.221]$} & {$[0.096]$} & {$[0.012]$} & {$[0.012]$} & $\begin{array}{l}0.250 \\
{[0.267]}\end{array}$ \\
\hline Non-Local $*$ female $* \mathrm{CU}$ land $\mathrm{LL}$ & & & & & & & & & $\begin{array}{c}-0.455^{* *} \\
{[0.168]}\end{array}$ \\
\hline Non-Local * CU land LH & & & & & & & & & $\begin{array}{c}1.375 * * * \\
{[0.267]}\end{array}$ \\
\hline Non-Local * female ${ }^{*} \mathrm{CU}$ land LH & & & & & & & & & $\begin{array}{c}-2.080^{* * * *} \\
{[0.168]}\end{array}$ \\
\hline Non-Local * CU land $\mathrm{HL}$ & & & & & & & & & $\begin{array}{l}-0.222 \\
0.267]\end{array}$ \\
\hline Non-Local $*$ female $* \mathrm{CU}$ land $\mathrm{HL}$ & & & & & & & & & $\begin{array}{l}0.351^{*} \\
{[0.168]}\end{array}$ \\
\hline Constant & $\begin{array}{c}7.342^{* * *} \\
{[0.057]}\end{array}$ & $\begin{array}{c}7.342^{* * *} \\
{[0.047]}\end{array}$ & $\begin{array}{c}7.342^{* * *} \\
{[0.054]}\end{array}$ & $\begin{array}{c}7.342^{* * *} \\
{[0.039]}\end{array}$ & $\begin{array}{c}7.342^{* * *} \\
{[0.056]}\end{array}$ & $\begin{array}{c}7.342^{* * *} \\
{[0.055]}\end{array}$ & $\begin{array}{c}7.342^{* * *} \\
{[0.057]}\end{array}$ & $\begin{array}{c}7.342^{* * *} \\
{[0.057]}\end{array}$ & $\begin{array}{l}7.342^{* * * *} \\
{[0.056]}\end{array}$ \\
\hline $\mathrm{N}$ & 240 & 240 & 240 & 240 & 240 & 240 & 240 & 240 & 240 \\
\hline R-sq & 0.028 & 0.058 & 0.024 & 0.068 & 0.037 & 0.031 & 0.047 & 0.046 & 0.099 \\
\hline
\end{tabular}




\section{Appendix A}

\section{A1. Descriptive Statistics}

Table A1: Tightness of participant's network

\begin{tabular}{|c|c|c|c|}
\hline Location & Know other participants & Family of other participants & Meets other participants often \\
\hline Huntochac & 0.850 & 0.200 & 0.275 \\
\hline Manuel Cepeda Peraza & 0.950 & 0.132 & 0.175 \\
\hline Noh-Bec & 0.941 & $\begin{array}{l}0.132 \\
0.206\end{array}$ & 0.294 \\
\hline Chan-Chichimilá & 0.684 & 0.027 & 0.027 \\
\hline Chicán & 0.935 & 0.065 & 0.323 \\
\hline Cholul-Cantamayec & 0.968 & 0.300 & 0.226 \\
\hline $\begin{array}{l}\text { Muchucuxcáh } \\
\text { Mec }\end{array}$ & 0.816 & 0.053 & 0.081 \\
\hline $\begin{array}{l}\text { Muchuecúncan } \\
\text { Sachecan }\end{array}$ & 0.923 & $\begin{array}{l}0.033 \\
0.308\end{array}$ & 0.385 \\
\hline
\end{tabular}


Table A2: Balance of covariates - treatment

\begin{tabular}{|c|c|c|c|c|c|}
\hline \multirow[b]{2}{*}{ Variable } & \multicolumn{2}{|c|}{$\begin{array}{c}(1) \\
\text { Recipient }\end{array}$} & \multicolumn{2}{|c|}{$\begin{array}{c}(2) \\
\text { Donor }\end{array}$} & \multirow{2}{*}{$\begin{array}{c}\text { T-test } \\
\text { Difference } \\
(1)-(2)\end{array}$} \\
\hline & $\mathrm{N}$ & Mean/SE & $\mathrm{N}$ & Mean/SE & \\
\hline Age & 120 & $\begin{array}{c}39.467 \\
(1.295)\end{array}$ & 124 & $\begin{array}{l}37.903 \\
(1.010)\end{array}$ & 1.563 \\
\hline Female & 120 & $\begin{array}{c}0.567 \\
(0.045)\end{array}$ & 124 & $\begin{array}{c}0.613 \\
(0.044)\end{array}$ & -0.046 \\
\hline Married & 120 & $\begin{array}{c}0.750 \\
(0.040)\end{array}$ & 124 & $\begin{array}{c}0.734 \\
(0.040)\end{array}$ & 0.016 \\
\hline HH size & 118 & $\begin{array}{c}5.424 \\
(0.225)\end{array}$ & 122 & $\begin{array}{c}5.787 \\
(0.244)\end{array}$ & -0.363 \\
\hline Siblings & 120 & $\begin{array}{c}5.133 \\
(0.245)\end{array}$ & 124 & $\begin{array}{c}5.927 \\
(0.248)\end{array}$ & $-0.794^{* *}$ \\
\hline Children & 120 & $\begin{array}{c}3.400 \\
(0.270)\end{array}$ & 124 & $\begin{array}{c}3.476 \\
(0.245)\end{array}$ & -0.076 \\
\hline Born in municipality & 120 & $\begin{array}{c}0.733 \\
(0.041)\end{array}$ & 124 & $\begin{array}{c}0.734 \\
(0.040)\end{array}$ & -0.001 \\
\hline Only indigenous language & 120 & $\begin{array}{c}0.083 \\
(0.025)\end{array}$ & 124 & $\begin{array}{c}0.113 \\
(0.029)\end{array}$ & -0.030 \\
\hline Speaks spanish and indigenous language & 120 & $\begin{array}{c}0.908 \\
(0.026)\end{array}$ & 124 & $\begin{array}{c}0.879 \\
(0.029)\end{array}$ & 0.029 \\
\hline Indigenous identity & 117 & $\begin{array}{c}0.966 \\
(0.017)\end{array}$ & 123 & $\begin{array}{c}0.984 \\
(0.011)\end{array}$ & -0.018 \\
\hline Secondary education (subject) & 120 & $\begin{array}{c}0.350 \\
(0.044)\end{array}$ & 124 & $\begin{array}{c}0.355 \\
(0.043)\end{array}$ & -0.005 \\
\hline Secondary education $(\mathrm{HH})$ & 120 & $\begin{array}{c}0.808 \\
(0.036)\end{array}$ & 124 & $\begin{array}{c}0.758 \\
(0.039)\end{array}$ & 0.050 \\
\hline Ejidatario & 78 & $\begin{array}{c}0.808 \\
(0.045)\end{array}$ & 83 & $\begin{array}{c}0.723 \\
(0.049)\end{array}$ & 0.085 \\
\hline Dwelling index & 120 & $\begin{array}{c}0.046 \\
(0.119)\end{array}$ & 124 & $\begin{array}{c}-0.121 \\
(0.126)\end{array}$ & 0.167 \\
\hline Asset index & 120 & $\begin{array}{c}0.205 \\
(0.182)\end{array}$ & 124 & $\begin{array}{c}0.069 \\
(0.188)\end{array}$ & 0.137 \\
\hline Number celebrations & 120 & $\begin{array}{c}1.475 \\
(0.046)\end{array}$ & 124 & $\begin{array}{c}1.548 \\
(0.046)\end{array}$ & -0.073 \\
\hline F-test of joint significance (F-stat) & & & & & 0.940 \\
\hline F-test, number of observations & & & & & 157 \\
\hline
\end{tabular}


Table A3: Sociodemographic Characteristics of the Selected Localities

\begin{tabular}{|c|c|c|c|c|c|c|c|c|}
\hline Variables & Session Locality & Matched locality & Session Locality & Matched locality & Session Locality & Matched locality & Session Locality & Matched locality \\
\hline & Chan-Chichimila & Xanlah & Chican & Xaya & Cholul & Nenela & Huntochac & M. Cepeda Peraza \\
\hline Total population (persons) & 464 & 399 & 624 & 1814 & 412 & 250 & 304 & 573 \\
\hline Inhabited dwellings & 94 & 93 & 154 & 394 & 94 & 46 & 79 & 138 \\
\hline Rate women/men over 18 & 1.000 & 0.966 & 0.938 & 1.007 & 1.020 & 1.016 & 0.949 & 1.138 \\
\hline Fertility & 2.770 & 2.670 & 3.190 & 2.830 & 2.830 & 2.710 & 3.200 & 2.390 \\
\hline Share of indigenous population age $3+$ & 1.000 & 0.900 & 0.958 & 0.989 & 0.992 & 0.991 & 0.949 & 0.843 \\
\hline Share of indigenous population age $3+$ that do not speak Spanish & 0.324 & 0.056 & 0.253 & 0.278 & 0.360 & 0.356 & 0.110 & 0.028 \\
\hline Share of illiterate age $15+$ & 0.165 & 0.145 & 0.286 & 0.256 & 0.349 & 0.290 & 0.358 & 0.160 \\
\hline Average years of schooling age $15+$ & 6.170 & 5.900 & 5.310 & 5.080 & 4.680 & 4.920 & 4.590 & 6.300 \\
\hline Share of population age $12+$ married & 0.541 & 0.606 & 0.610 & 0.551 & 0.557 & 0.500 & 0.632 & 0.563 \\
\hline Share of Catholics & 0.998 & 0.817 & 0.753 & 0.858 & 0.816 & 0.472 & 0.648 & 0.323 \\
\hline \multirow{3}{*}{$\begin{array}{l}\text { Share of non-Catholic Christlans } \\
\text { Religious homogeneity index }\end{array}$} & 0.000 & 0.115 & 0.245 & 0.042 & 0.090 & 0.440 & 0.207 & 0.585 \\
\hline & 0.996 & 0.681 & 0.627 & 0.739 & 0.673 & 0.416 & 0.463 & 0.446 \\
\hline & Muchucuxcah & Ichmul & Noh-Bec & Dzi & Sacbecan & Corral & M. Cepeda Peraza & Sacbecan \\
\hline Total population (persons) & 318 & 911 & 362 & 491 & 236 & 336 & 573 & 236 \\
\hline Inhabited dwellings & 67 & 202 & 77 & 114 & 49 & 74 & 138 & 49 \\
\hline Rate women/men over 18 & 0.860 & 0.968 & 0.989 & 0.988 & 0.844 & 1.087 & 1.138 & 0.844 \\
\hline Fertility & 3.130 & 2.960 & 2.930 & 2.990 & 2.930 & 2.940 & 2.390 & 2.930 \\
\hline Share of indigenous population age $3+$ & 0.993 & 0.959 & 0.877 & 0.644 & 0.917 & 0.482 & 0.843 & 0.917 \\
\hline Share of indigenous population age $3+$ that do not speak Spanish & 0.089 & 0.152 & 0.015 & 0.045 & 0.032 & 0.023 & 0.028 & 0.032 \\
\hline Share of illiterate age $15+$ & 0.193 & 0.174 & 0.211 & 0.155 & 0.170 & 0.223 & 0.160 & 0.170 \\
\hline Average years of schooling age $15+$ & 5.200 & 5.690 & 4.980 & 6.710 & 5.020 & 5.550 & 6.300 & 5.020 \\
\hline Share of population age $12+$ married & 0.584 & 0.594 & 0.618 & 0.577 & 0.554 & 0.633 & 0.563 & 0.554 \\
\hline Share of Catholics & 0.503 & 0.986 & 0.525 & 0.984 & 0.127 & 0.491 & 0.323 & 0.127 \\
\hline Share of non-Catholic Christians & 0.481 & 0.013 & 0.312 & 0.014 & 0.530 & 0.408 & 0.585 & 0.530 \\
\hline Religious homogeneity index & 0.485 & 0.972 & 0.373 & 0.968 & 0.297 & 0.407 & 0.446 & 0.297 \\
\hline
\end{tabular}

Source: National Institute of Geography and Statistics (INEGI), National Census 2010

Table A4: Geographic and Productive Characteristics of the Selected Localities

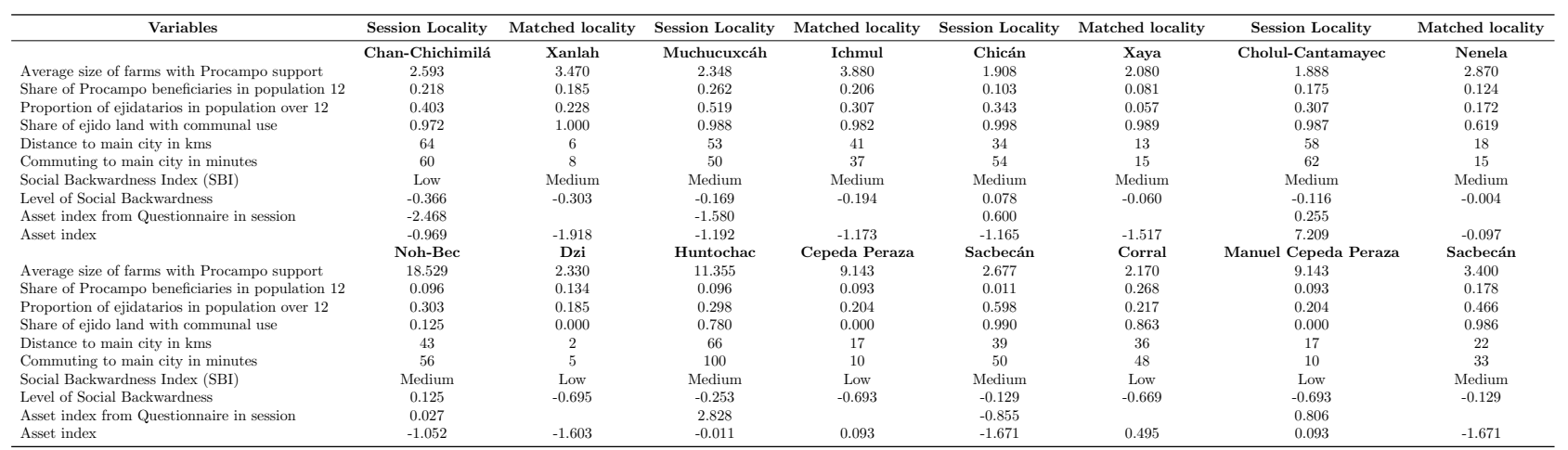

Source: National Institute of Geography and Statistics (INEGI), National Census 2010 and National Agrarian Registry Office.

The Program for Direct Income Support to Farmers (PROCAMPO), this indicator represents the average size of the plot for farmers in the locality. National Agrarian Registry Office. Proportion of people over 12 years in locality with ejido land tenure. This indicator refers to the share of land in the Ejido dedicated for the communal use, usually forest. The average commuting time, obtained form googlemaps, from the center of the locality to the nearest main city with more than 10,000 inhabitants. The National Council for Evaluation of Social Development Policy develops the social backwardness index (SBO) to rank the lackness of social opportunities and the absence of capabilities, privations or inaccessibility to goods and services that reflect the social welfare. This index considers 15 categories of exclusion in four dimensions: education, access to health services, basic services and quality of dwelling. The SBI is calculated using the principal component analysis technique. The SBI goes from -2 which reflect very low backwardness to +3 that indicate very high level of social backwardness. In addition,
five cardinal categories of social backwardness are defined: very low, low, medium, high and very high. The asset index was calculated using the principal factor analysis method that considers the following assets: properties, motor vehicles, durable and appliances, agricultural and farm assets, cattle and books. 
Table A5: Differences in Mean Geographic and Productive Characteristics Between Session and Matched Localities

\begin{tabular}{|c|c|c|c|}
\hline Variable & $\begin{array}{c}(1) \\
\text { Session }\end{array}$ & $\begin{array}{c}(2) \\
\text { Matched }\end{array}$ & $\begin{array}{c}(3) \\
\text { Difference }\end{array}$ \\
\hline Total population (persons) & 411.625 & 626.250 & 214.625 \\
\hline & $(134.984)$ & $(526.811)$ & $(192.273)$ \\
\hline Rate women/men over 18 & $\begin{array}{l}0.967 \\
(0.094)\end{array}$ & $\begin{array}{l}1.002 \\
(0.088)\end{array}$ & $\begin{array}{c}0.034 \\
(0.045)\end{array}$ \\
\hline Fertility & $\begin{array}{c}2.921 \\
(0.269)\end{array}$ & $\begin{array}{l}2.803 \\
(0.204)\end{array}$ & $\begin{array}{l}-0.119 \\
(0.119)\end{array}$ \\
\hline Share of indigenous population age $3+$ & $\begin{array}{c}0.941 \\
(0.058)\end{array}$ & $\begin{array}{c}0.840 \\
(0.183)\end{array}$ & $\begin{array}{l}-0.100 \\
(0.068)\end{array}$ \\
\hline Share of indigenous population age $3+$ that do not speak Spanish & $\begin{array}{c}0.152 \\
(0.140)\end{array}$ & $\begin{array}{c}0.121 \\
(0.129)\end{array}$ & $\begin{array}{l}-0.030 \\
(0.067)\end{array}$ \\
\hline Share of illiterate age $15+$ & $\begin{array}{c}0.236 \\
(0.083)\end{array}$ & $\begin{array}{c}0.197 \\
(0.053)\end{array}$ & $\begin{array}{l}-0.040 \\
(0.035)\end{array}$ \\
\hline Average years of schooling age $15+$ & $\begin{array}{c}5.281 \\
(0.636)\end{array}$ & $\begin{array}{l}5.646 \\
(0.641)\end{array}$ & $\begin{array}{c}0.365 \\
(0.319)\end{array}$ \\
\hline Share of population age $12+$ married & $\begin{array}{c}0.582 \\
(0.034)\end{array}$ & $\begin{array}{c}0.572 \\
(0.040)\end{array}$ & $\begin{array}{l}-0.010 \\
(0.019)\end{array}$ \\
\hline Share of Catholics & $\begin{array}{c}0.587 \\
(0.279)\end{array}$ & $\begin{array}{c}0.632 \\
(0.323)\end{array}$ & $\begin{array}{c}0.046 \\
(0.151)\end{array}$ \\
\hline Share of non-Catholic Christians & $\begin{array}{c}0.306 \\
(0.211)\end{array}$ & $\begin{array}{l}0.268 \\
(0.245)\end{array}$ & $\begin{array}{l}-0.038 \\
(0.114)\end{array}$ \\
\hline Religious homogeneity index & $\begin{array}{c}0.545 \\
(0.220)\end{array}$ & $\begin{array}{c}0.616 \\
(0.263)\end{array}$ & $\begin{array}{c}0.071 \\
(0.121)\end{array}$ \\
\hline Average size of farms with Procampo support & $\begin{array}{l}6.305 \\
(6.146)\end{array}$ & $\begin{array}{l}3.568 \\
(2.334)\end{array}$ & $\begin{array}{l}-2.738 \\
(2.324)\end{array}$ \\
\hline Share of Procampo beneficiaries in population & $\begin{array}{c}0.132 \\
(0.081)\end{array}$ & $\begin{array}{c}0.138 \\
(0.081)\end{array}$ & $\begin{array}{c}0.006 \\
(0.040)\end{array}$ \\
\hline Proportion of ejidatarios in population over 12 & $\begin{array}{c}0.372 \\
(0.129)\end{array}$ & $\begin{array}{l}0.246 \\
(0.158)\end{array}$ & $\begin{array}{l}-0.126 \\
(0.072)\end{array}$ \\
\hline Share of ejido land with communal use & $\begin{array}{c}0.730 \\
(0.419)\end{array}$ & $\begin{array}{c}0.680 \\
(0.439)\end{array}$ & $\begin{array}{l}-0.050 \\
(0.215)\end{array}$ \\
\hline Distance to main city in $\mathrm{kms}$ & $\begin{array}{c}46.750 \\
(16.714)\end{array}$ & $\begin{array}{c}21.500 \\
(15.222)\end{array}$ & $\begin{array}{c}-25.250^{* * *} \\
(7.993)\end{array}$ \\
\hline Commuting to main city in minutes & $\begin{array}{c}49.500 \\
(29.621)\end{array}$ & $\begin{array}{c}23.500 \\
(18.493)\end{array}$ & $\begin{array}{l}-26.000^{*} \\
(12.346)\end{array}$ \\
\hline Asset index from Questionnaire in session & $\begin{array}{l}-0.095 \\
(1.615)\end{array}$ & $\begin{array}{l}-0.025 \\
(1.175)\end{array}$ & $\begin{array}{c}0.070 \\
(1.239)\end{array}$ \\
\hline Asset index & $\begin{array}{c}-0.192 \\
(2.505) \\
\end{array}$ & $\begin{array}{r}-0.923 \\
(0.939) \\
\end{array}$ & $\begin{array}{c}-0.731 \\
(0.946) \\
\end{array}$ \\
\hline Observations & 8 & 8 & 16 \\
\hline
\end{tabular}

Source: National Institute of Geography and Statistics (INEGI), National Census 2010 and National Agrarian Registry Office.

The Program for Direct Income Support to Farmers (PROCAMPO), this indicator represents the average size of the plot for farmers in the locality. National Agrarian Registry Office. Proportion of people over 12 years in locality with ejido land tenure. This indicator refers to the share of land in the Ejido dedicated for the communal use, usually forest. The average commuting time, obtained form googlemaps, from the center of the locality to the nearest main city with more than 10,000 inhabitants. The National Council for Evaluation of Social Development Policy develops the social backwardness index (SBO) to rank the lackness of social opportunities and the absence of capabilities, privations or inaccessibility to goods and services that reflect the social welfare. This index considers 15
categories of exclusion in four dimensions: education, access to health services, basic services and quality of dwelling. The SBI is calculated using the principal component analysis technique. The SBI goes from -2 which reflect very low backwardness to +3 that indicate very high level of social backwardness. In addition, five cardinal categories of social backwardness are defined: very low, low, medium, high and very high. The asset index was calculated using the principal factor analysis method that considers the following assets: properties, motor vehicles, durable and appliances, agricultural and farm assets, cattle and books. 
Table A6: Summary statistics - Locality vs. subject characteristics

\begin{tabular}{|c|c|c|c|c|c|}
\hline \multirow[b]{2}{*}{ Variable } & \multicolumn{2}{|c|}{ Subjects } & \multicolumn{2}{|c|}{ CENSUS information } & \multirow[b]{2}{*}{ P-value } \\
\hline & Mean & SE & Mean & SE & \\
\hline Proportion women $/ \mathrm{men}$, older than 18 & 1.595 & 0.670 & 0.951 & 0.105 & 0.000 \\
\hline Fertility, children per women & 3.444 & 2.821 & 2.920 & 0.249 & 0.000 \\
\hline Proportion of $18-24$ years old women in total population & 0.055 & 0.016 & 0.077 & 0.011 & 0.000 \\
\hline Proportion of $15-49$ years old women in total population & 0.489 & 0.082 & 0.264 & 0.026 & 0.000 \\
\hline Proportion of singles in total population & 0.109 & 0.087 & 0.405 & 0.038 & 0.000 \\
\hline Proportion of married in total population & 0.847 & 0.100 & 0.643 & 0.039 & 0.000 \\
\hline Proportion of divorced, separated and widows in total population & 0.044 & 0.034 & 0.056 & 0.016 & 0.000 \\
\hline Proportion of population that speaks only indigenous language & 0.097 & 0.095 & 0.149 & 0.131 & 0.000 \\
\hline Proportion of population that speaks indigenous language and Spanish & 0.895 & 0.095 & 0.790 & 0.096 & 0.000 \\
\hline Proportion of population older than 15 with no formal education & 0.149 & 0.136 & 0.138 & 0.052 & 0.010 \\
\hline Proportion of population older than 15 with high school education & 0.278 & 0.128 & 0.210 & 0.034 & 0.000 \\
\hline Proportion of people born in State & 0.553 & 0.338 & 0.991 & 0.012 & 0.000 \\
\hline Proportion of one-room dwellings & 0.464 & 0.129 & 0.206 & 0.089 & 0.000 \\
\hline Proportion of two-rooms dwellings & 0.379 & 0.090 & 0.408 & 0.070 & 0.000 \\
\hline Proportion of dwellings with more than three rooms & 0.157 & 0.065 & 0.385 & 0.060 & 0.000 \\
\hline Proportion of dwellings with piped water in property & 0.911 & 0.037 & 0.935 & 0.051 & 0.000 \\
\hline Proportion of dwellings with electricity & 0.919 & 0.059 & 0.954 & 0.024 & 0.000 \\
\hline
\end{tabular}

Note: We compare on proportion of people born in State from ITER vs. Proportion of people born in municipality of our sample

Table A7: Participants' giving and receiving patterns

\begin{tabular}{|c|c|c|c|c|c|c|c|}
\hline & \multicolumn{6}{|c|}{ Giving and Receiving patterns } & \multirow[t]{3}{*}{ Obs. } \\
\hline & \multicolumn{2}{|c|}{ Giving } & \multicolumn{2}{|c|}{ Receiving } & \multicolumn{2}{|c|}{ Reason } & \\
\hline & Individual & Household & Individual & Household & Voluntary & Reciprocity & \\
\hline Huntochac & 0.290 & 0.581 & 0.333 & 0.533 & 0.938 & 0.063 & 33 \\
\hline Manuel Cepeda Peraza & 0.429 & 0.750 & 0.200 & 0.467 & 0.950 & 0.000 & 30 \\
\hline Noh-Bec & 0.387 & 0.581 & 0.387 & 0.516 & 0.824 & 0.176 & 31 \\
\hline Chan-Chichimilá & 0.343 & 0.371 & 0.257 & 0.314 & 0.833 & 0.167 & 35 \\
\hline Chicán & 0.296 & 0.333 & 0.481 & 0.556 & 0.778 & 0.222 & 27 \\
\hline Cholul-Cantamayec & 0.393 & 0.536 & 0.714 & 0.821 & 0.800 & 0.000 & 28 \\
\hline Muchucuxcáh & 0.267 & 0.367 & 0.258 & 0.484 & 1.000 & 0.000 & 31 \\
\hline Sacbecán & 0.516 & 0.581 & 0.242 & 0.548 & 0.778 & 0.222 & 33 \\
\hline
\end{tabular}


Table A8: Gender mean differences in giving and receiving, community involvement and trust, knowledge of other participants and matched locality and sociodemographic characteristics

\begin{tabular}{|c|c|c|c|c|}
\hline Variable & $\begin{array}{c}(1) \\
\text { Male } \\
\end{array}$ & $\begin{array}{c}(2) \\
\text { Female }\end{array}$ & $\begin{array}{c}(3) \\
\text { Difference }\end{array}$ & $\begin{array}{l}(4) \\
\mathrm{N}\end{array}$ \\
\hline \multicolumn{5}{|l|}{ A. Giving and receiving patterns } \\
\hline Respondent's household gave help during last year & $\begin{array}{c}0.552 \\
(0.500)\end{array}$ & $\begin{array}{c}0.475 \\
(0.501)\end{array}$ & $\begin{array}{l}-0.077 \\
(0.066)\end{array}$ & 237 \\
\hline Help given was sporadic (one-time/a few times) & $\begin{array}{c}0.875 \\
(0.334)\end{array}$ & $\begin{array}{c}0.905 \\
(0.296)\end{array}$ & $\begin{array}{c}0.030 \\
(0.060)\end{array}$ & 111 \\
\hline Help given was within same locality & $\begin{array}{c}0.667 \\
(0.476)\end{array}$ & $\begin{array}{c}0.797 \\
(0.406)\end{array}$ & $\begin{array}{c}0.130 \\
(0.082)\end{array}$ & 115 \\
\hline Help given is voluntary & $\begin{array}{c}0.922 \\
(0.272)\end{array}$ & $\begin{array}{c}0.810 \\
(0.396)\end{array}$ & $\begin{array}{c}-0.112^{*} \\
(0.065)\end{array}$ & 114 \\
\hline Help given is due to pressure & $\begin{array}{c}0.039 \\
(0.196)\end{array}$ & $\begin{array}{c}0.032 \\
(0.177)\end{array}$ & $\begin{array}{l}-0.007 \\
(0.035)\end{array}$ & 114 \\
\hline Help given is due to reciprocity & $\begin{array}{c}0.039 \\
(0.196)\end{array}$ & $\begin{array}{c}0.159 \\
(0.368)\end{array}$ & $\begin{array}{c}0.120^{* *} \\
(0.057)\end{array}$ & 114 \\
\hline Respondent received any help during last year & $\begin{array}{c}0.350 \\
(0.479)\end{array}$ & $\begin{array}{c}0.354 \\
(0.480)\end{array}$ & $\begin{array}{c}0.004 \\
(0.062)\end{array}$ & 244 \\
\hline Respondent's household received any help during last year & $\begin{array}{c}0.561 \\
(0.499)\end{array}$ & $\begin{array}{c}0.489 \\
(0.502)\end{array}$ & $\begin{array}{l}-0.072 \\
(0.066)\end{array}$ & 239 \\
\hline Help received was sporadic (one-time/a few times) & $\begin{array}{c}0.830 \\
(0.379)\end{array}$ & $\begin{array}{c}0.875 \\
(0.333)\end{array}$ & $\begin{array}{c}0.045 \\
(0.066)\end{array}$ & 117 \\
\hline Help received is from within same locality & $\begin{array}{c}0.385 \\
(0.491)\end{array}$ & $\begin{array}{c}0.452 \\
(0.502)\end{array}$ & $\begin{array}{c}0.067 \\
(0.093)\end{array}$ & 114 \\
\hline B. Community involvement and trust & & & & \\
\hline Believes locality cooperates to solve problems most of the time/always & $\begin{array}{c}0.380 \\
(0.488)\end{array}$ & $\begin{array}{c}0.299 \\
(0.459)\end{array}$ & $\begin{array}{l}-0.081 \\
(0.061)\end{array}$ & 244 \\
\hline Fraction in her locality who believe people cooperate most of the time/always & $\begin{array}{c}0.326 \\
(0.125)\end{array}$ & $\begin{array}{c}0.331 \\
(0.124)\end{array}$ & $\begin{array}{c}0.005 \\
(0.016)\end{array}$ & 244 \\
\hline Number of organizations the respondent participates in & $\begin{array}{c}1.780 \\
(1.268)\end{array}$ & $\begin{array}{c}2.236 \\
(1.491)\end{array}$ & $\begin{array}{c}0.456^{* *} \\
(0.183)\end{array}$ & 244 \\
\hline Number of celebrations the respondent participates in & $\begin{array}{c}2.740 \\
(1.125)\end{array}$ & $\begin{array}{c}2.972 \\
(1.064)\end{array}$ & $\begin{array}{c}0.232 \\
(0.142)\end{array}$ & 244 \\
\hline Believes generally you can trust most people & $\begin{array}{l}0.230 \\
(0.423)\end{array}$ & $\begin{array}{l}0.049 \\
(0.216)\end{array}$ & $\begin{array}{l}-0.181^{* * *} * \\
(0.041)\end{array}$ & 244 \\
\hline Believes most people would treat her fairly & $\begin{array}{l}0.630 \\
(0.485)\end{array}$ & $\begin{array}{l}0.563 \\
(0.498)\end{array}$ & $\begin{array}{l}-0.068 \\
(0.064)\end{array}$ & 244 \\
\hline Believes effort is rewarded with higher income most of the time/always & $\begin{array}{l}0.310 \\
(0.465)\end{array}$ & $\begin{array}{l}0.326 \\
(0.471)\end{array}$ & $\begin{array}{l}0.016 \\
(0.061)\end{array}$ & 244 \\
\hline Has some trust in govt. spending taxes adequately & $\begin{array}{l}0.780 \\
(0.416)\end{array}$ & $\begin{array}{c}0.741 \\
(0.439)\end{array}$ & $\begin{array}{l}-0.039 \\
(0.056)\end{array}$ & 243 \\
\hline Has high trust in govt. spending taxes adequately & $\begin{array}{l}0.130 \\
(0.338)\end{array}$ & $\begin{array}{c}0.126 \\
(0.333)\end{array}$ & $\begin{array}{l}-0.004 \\
(0.044)\end{array}$ & 243 \\
\hline $\begin{array}{l}\text { C. Knowledge of other participants and matched locality } \\
\text { Knows all/almost all the other participants }\end{array}$ & $\begin{array}{l}0.880 \\
(0.327)\end{array}$ & $\begin{array}{l}0.868 \\
(0.340)\end{array}$ & $\begin{array}{l}-0.012 \\
(0.044)\end{array}$ & 244 \\
\hline More than half of participants belong to her family & $\begin{array}{c}0.143 \\
(0.352)\end{array}$ & $\begin{array}{c}0.146 \\
(0.354)\end{array}$ & $\begin{array}{c}0.003 \\
(0.046)\end{array}$ & 242 \\
\hline Shares daily activities with more than half of participants & $\begin{array}{c}0.172 \\
(0.379)\end{array}$ & $\begin{array}{c}0.245 \\
(0.431)\end{array}$ & $\begin{array}{c}0.073 \\
(0.054)\end{array}$ & 242 \\
\hline Knows matched village for global game & $\begin{array}{c}0.480 \\
(0.502)\end{array}$ & $\begin{array}{c}0.507 \\
(0.502)\end{array}$ & $\begin{array}{c}0.027 \\
(0.065)\end{array}$ & 244 \\
\hline Has visited matched village for global game & $\begin{array}{c}0.380 \\
(0.488)\end{array}$ & $\begin{array}{c}0.368 \\
(0.484)\end{array}$ & $\begin{array}{l}-0.012 \\
(0.063)\end{array}$ & 244 \\
\hline Has been to the health clinic of matched village for global game & $\begin{array}{c}0.260 \\
(0.441)\end{array}$ & $\begin{array}{c}0.299 \\
(0.459)\end{array}$ & $\begin{array}{c}0.039 \\
(0.059)\end{array}$ & 244 \\
\hline D. Respondent sociodemographic characteristics & & & & \\
\hline Age & $\begin{array}{c}39.290 \\
(15.177)\end{array}$ & $\begin{array}{c}38.243 \\
(10.840)\end{array}$ & $\begin{array}{l}-1.047 \\
(1.665)\end{array}$ & 244 \\
\hline Has at least some secondary education & $\begin{array}{c}0.480 \\
(0.502)\end{array}$ & $\begin{array}{c}0.264 \\
(0.442)\end{array}$ & $\begin{array}{c}-0.216^{* * * *} \\
(0.061)\end{array}$ & 244 \\
\hline Married & $\begin{array}{c}0.680 \\
(0.469)\end{array}$ & $\begin{array}{c}0.785 \\
(0.412)\end{array}$ & $\begin{array}{l}0.105^{*} \\
(0.057)\end{array}$ & 244 \\
\hline Born in the munincipality where she currently resides & $\begin{array}{c}0.770 \\
(0.423)\end{array}$ & $\begin{array}{c}0.708 \\
(0.456)\end{array}$ & $\begin{array}{l}-0.062 \\
(0.058)\end{array}$ & 244 \\
\hline Number of siblings & $\begin{array}{c}5.210 \\
(2.724)\end{array}$ & $\begin{array}{c}5.764 \\
(2.748)\end{array}$ & $\begin{array}{c}0.554 \\
(0.356)\end{array}$ & 244 \\
\hline Number of children & $\begin{array}{c}2.990 \\
(3.070)\end{array}$ & $\begin{array}{c}3.750 \\
(2.630)\end{array}$ & $\begin{array}{c}0.760^{* *} \\
(0.367)\end{array}$ & 244 \\
\hline Household receives support from Oportunidades program & $\begin{array}{c}0.820 \\
(0.386)\end{array}$ & $\begin{array}{c}0.882 \\
(0.324)\end{array}$ & $\begin{array}{c}0.062 \\
(0.046)\end{array}$ & 244 \\
\hline Household receives non-contributory public pensions & $\begin{array}{c}0.190 \\
(0.394)\end{array}$ & $\begin{array}{c}0.174 \\
(0.380)\end{array}$ & $\begin{array}{l}-0.016 \\
(0.050)\end{array}$ & 244 \\
\hline Household receives support from Procampo program & $\begin{array}{c}0.660 \\
(0.476)\end{array}$ & $\begin{array}{c}0.604 \\
(0.491)\end{array}$ & $\begin{array}{l}-0.056 \\
(0.063)\end{array}$ & 244 \\
\hline Number of government program the household receives support from & $\begin{array}{c}2.550 \\
(1.731)\end{array}$ & $\begin{array}{c}2.472 \\
(1.399)\end{array}$ & $\begin{array}{l}-0.078 \\
(0.201)\end{array}$ & 244 \\
\hline Household in the lowest wealth quartile & $\begin{array}{c}0.290 \\
(0.456)\end{array}$ & $\begin{array}{c}0.215 \\
(0.412)\end{array}$ & $\begin{array}{l}-0.075 \\
(0.056)\end{array}$ & 244 \\
\hline Household in the highest wealth quartile & $\begin{array}{c}0.250 \\
(0.435) \\
\end{array}$ & $\begin{array}{c}0.257 \\
(0.438) \\
\end{array}$ & $\begin{array}{c}0.007 \\
(0.057) \\
\end{array}$ & 244 \\
\hline
\end{tabular}

F-statistics. ***, **, and * indicate significance at the 1,5 , and 10 percent critical level. 


\section{A2. Additional Estimations and Robustness Checks}

Table A9: Robustness to order of the games

\begin{tabular}{|c|c|c|c|c|}
\hline & (1) & $(2)$ & \multicolumn{2}{|r|}{$(4)$} \\
\hline & \multicolumn{2}{|c|}{ Recipients } & \multicolumn{2}{|c|}{ Donors } \\
\hline Non-Local game & $\begin{array}{c}-0.0667 \\
(0.125)\end{array}$ & $\begin{array}{c}-0.2778 \\
(0.323)\end{array}$ & $\begin{array}{c}0.1562 \\
(0.098)\end{array}$ & $\begin{array}{c}-0.0909^{*} \\
(0.045)\end{array}$ \\
\hline Non-Local $*$ Female & & $\begin{array}{c}0.3016 \\
(0.290)\end{array}$ & & $\begin{array}{c}0.3766^{* * *} \\
(0.088)\end{array}$ \\
\hline Non-Local * Order & $\begin{array}{c}0.4333^{* *} \\
(0.170)\end{array}$ & $\begin{array}{c}0.7190+ \\
(0.444)\end{array}$ & $\begin{array}{c}-0.0229 \\
(0.208)\end{array}$ & $\begin{array}{c}-0.1399 \\
(0.175)\end{array}$ \\
\hline Non-Local*Female*Order & & $\begin{array}{c}-0.4735 \\
(0.578)\end{array}$ & & $\begin{array}{c}0.2659^{* *} \\
(0.101)\end{array}$ \\
\hline Constant & $\begin{array}{c}7.3417^{* * * *} \\
(0.043) \\
\end{array}$ & $\begin{array}{c}7.3417^{* * *} \\
(0.042) \\
\end{array}$ & $\begin{array}{c}7.2016^{* * *} \\
(0.051) \\
\end{array}$ & $\begin{array}{c}7.2016^{* * *} \\
(0.048) \\
\end{array}$ \\
\hline Observations & 240 & 240 & 248 & 248 \\
\hline$R^{2}$ & 0.042 & 0.050 & 0.028 & 0.114 \\
\hline Number of player & 120 & 120 & 124 & 124 \\
\hline $\begin{array}{l}\text { Notes: Robust standard er } \\
* \mathrm{p}<0.1,+\mathrm{p}<0.15 \text {. Unit } \\
\text { LPG game. Subject fixed e } \\
\text { The variable Order is a du } \\
\text { LPG and the NLPG games }\end{array}$ & $\begin{array}{l}\text { s in paren } \\
\text { bservation } \\
\text { ts include } \\
\text { ny that ta } \\
\text { one round }\end{array}$ & $\begin{array}{l}\text { eses, clus } \\
\text { a player } \\
\text { in all spe } \\
\text { s value }\end{array}$ & $\begin{array}{l}\text { session. } \\
\text { fort choic } \\
\text { ations. } \\
\text { when the }\end{array}$ & $\begin{array}{l}.01, * * \mathrm{p}<0.05, \\
\text { ame. Reference } \\
\text { ace between the }\end{array}$ \\
\hline
\end{tabular}

Table A10: Robustness to additional effort measures

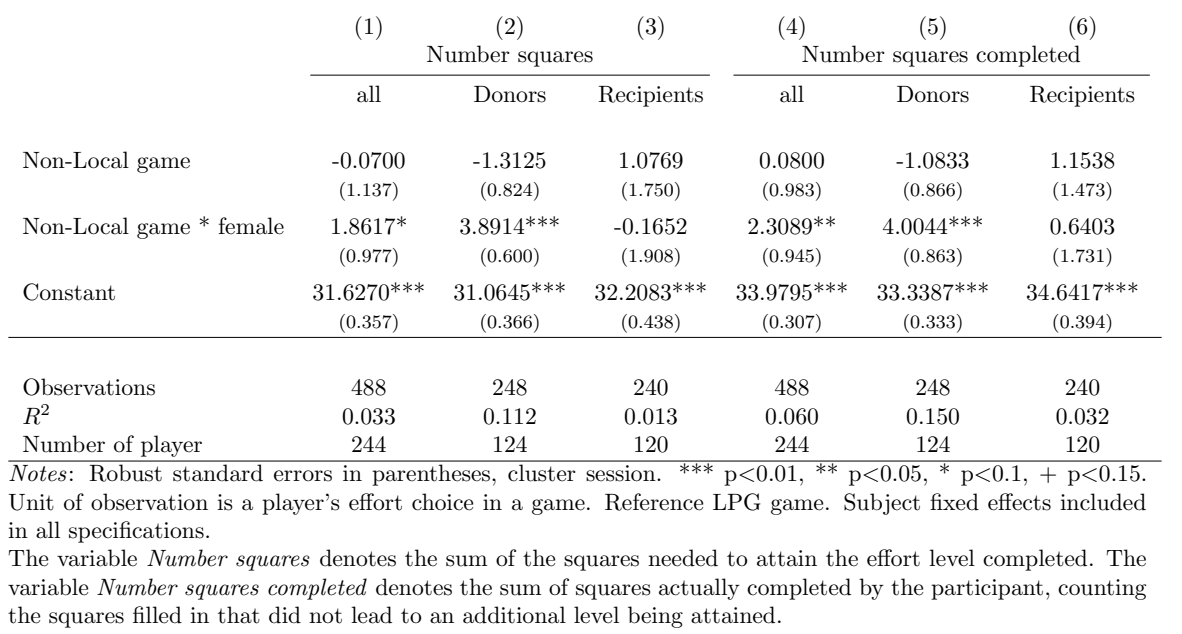




\section{A3. Ability and Learning}

In this appendix we present a detailed description of the game orders used in the experiment and a descriptive analysis of the experimental ability measure. We also present a discussion on the possible learning along the session that could be a confounding factor on the games comparison.

Table A11 shows the two game orders that were allocated randomly to the different sessions, as well as the number of participants on each of the orders. The main difference between the two orders is that the two games of interest, the LPG and the NLPG games, are separated by two rounds in Order A and by one round in Order B. Hence, it could be argued that the difference between the effort performed in each of the two games could be driven by the learning given by the difference in rounds between the games.

Table A11: Game orders used in the experiment

\begin{tabular}{|c|c|c|c|c|c|c|c|}
\hline & $\begin{array}{l}\text { First } \\
\text { game }\end{array}$ & $\begin{array}{l}\text { Second } \\
\text { game }\end{array}$ & $\begin{array}{l}\text { Third } \\
\text { game }\end{array}$ & $\begin{array}{l}\text { Fourth } \\
\text { game }\end{array}$ & $\begin{array}{l}\text { Number of } \\
\text { sessions }\end{array}$ & $\begin{array}{l}\text { Number of } \\
\text { participants }\end{array}$ & $\begin{array}{l}\text { Rounds between } \\
\text { public good games }\end{array}$ \\
\hline \begin{tabular}{ll|} 
Order & $A$ \\
\end{tabular} & Autarky & One-to-one & Local PG & Non-Local PG & 4 & 126 & 1 \\
\hline Order B & Autarky & Local PG & One-to-one & Non-Local PG & 4 & 122 & 2 \\
\hline
\end{tabular}

In Figure A1 we present the average effort levels across rounds for the different treatments - Donors and Recipients- and by gender. The game where transfers affect the local health center is marked in lighter bars (round 2 for Order A and round 3 for Order B), while the game related to the neighbor village health center is always played last (round 4). For all orders in the Donor treatment and for Order A in the Recipient treatment the figure shows that male participants perform less effort in the last round (NLPG) than in the lighter bar (LPG), and that this pattern does not hold for female participants.
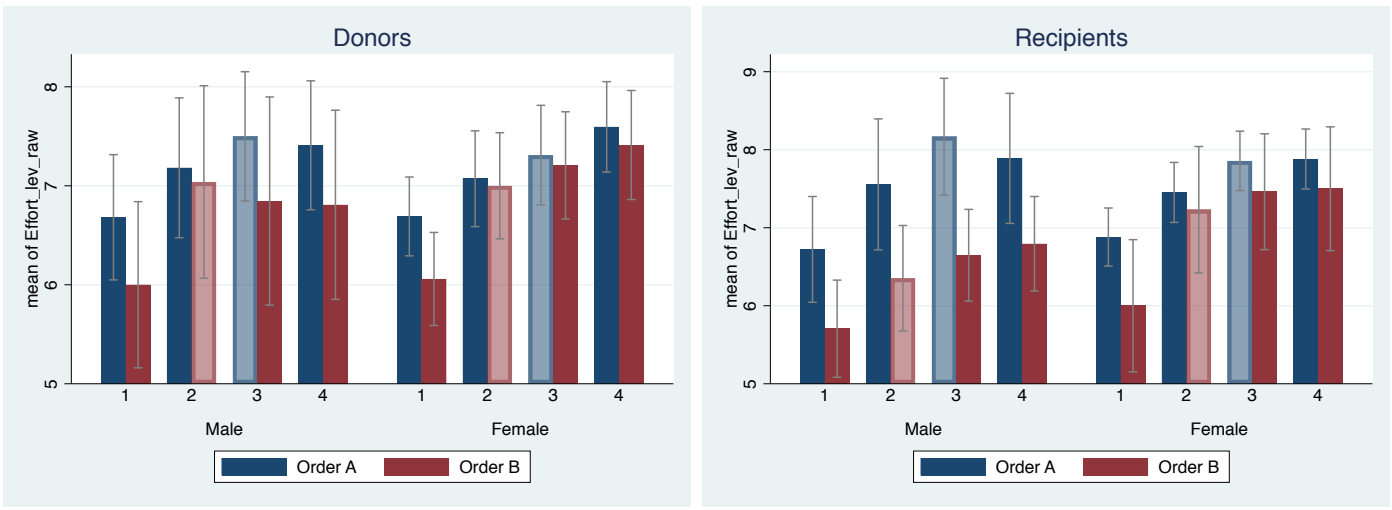

Figure A1: The Figures show, for Donors and Recipientsrespectively, the average effort levels per round for the different game orderings. Order A refers to the order "Autarky - One to One - Local - Neighbor" and Order B refers to the order "Autarky Local - One to One - Neighbor". The game where transfers affect the local health center is marked in lighter bars (round 2 for Order A and round 3 for Order B), while the game related to the neighbor village health center is always played last (round 4). For all orders in the Donor treatment the figure shows that male participants perform less effort in the last round (neighboring health center) than in the lighter bar (local health center), and that this pattern does not hold for female participants.

To illustrate the effect of learning, we estimate

$$
e_{i r o}=\mu+\gamma_{2}\left(\operatorname{Round}_{2 \text { iro }}\right)+\gamma_{3}\left(\operatorname{Round} 3_{\text {iro }}\right)+\gamma_{4}\left(\operatorname{Round}_{i r o}\right)+\delta_{i}+u_{i g}
$$

where $\gamma_{r}$ gives an estimation of the difference of effort across rounds taking the game played in the first round as reference. Column 1 in Table A12 shows that from first to second round the increase in effort is of 0.74 levels $\left(\gamma_{2}\right)$, and this coefficient is significantly smaller than $\gamma_{3}(=1)$ and $\gamma_{4}(=1.06)$. However, $\gamma_{3}$ and $\gamma_{4}$ are not significantly different. 
Columns 3 to 5 in Table A12 look at whether the round effect is different for the different game orders, following the specification of Equation A2 . If all the effort difference across games were only explained by learning, then it would be the case that $\theta_{2}, \theta_{3}$ and $\theta_{4}$ would be equal to zero, and round coefficients would be unchanged. In Column (2) we show that is not the case: we can not reject that the order of the games has no impact on effort across rounds. Moreover, Columns (4) and (5) show that the interaction terms are significantly different for male and female participants.

$$
\begin{aligned}
e_{i r o} & =\mu+\gamma_{2}\left(\operatorname{Round}_{i r o}\right)+\gamma_{3}\left(\operatorname{Round}_{i_{\text {iro }}}\right)+\gamma_{4}\left(\operatorname{Round} 4_{\text {iro }}\right) \\
& +\theta_{2}\left(\operatorname{Round} 2_{\text {iro }}\right) * \operatorname{Order} \mathrm{A}+\theta_{3}\left(\operatorname{Round} 3_{\text {iro }}\right) * \operatorname{Order} \mathrm{A}+\theta_{4}\left(\operatorname{Round} 4_{\text {iro }}\right) * \operatorname{Order} \mathrm{A}+\delta_{i}+u_{i g}
\end{aligned}
$$

To further study analyze whether the difference between effort is due to the orders (and hence to game conditions) or to participants characteristics, we present in Columns (5) to (7) the interaction of the rounds with gender, and show that there are not significant differences.

\begin{tabular}{|c|c|c|c|c|c|c|c|}
\hline Sample & $\begin{array}{l}(1) \\
\text { all }\end{array}$ & $\begin{array}{l}\text { (2) } \\
\text { all }\end{array}$ & $\begin{array}{c}(3) \\
\text { female }\end{array}$ & $\begin{array}{c}(4) \\
\text { male }\end{array}$ & $\begin{array}{l}\text { (5) } \\
\text { all }\end{array}$ & $\begin{array}{c}(6) \\
\text { orderA }\end{array}$ & $\begin{array}{c}(7) \\
\text { orderB }\end{array}$ \\
\hline Round 2 & $\begin{array}{c}0.7419^{* * *} \\
(0.100)\end{array}$ & $\begin{array}{c}0.5556^{* * *} \\
(0.114)\end{array}$ & $\begin{array}{c}0.4762^{* *} \\
(0.167)\end{array}$ & $\begin{array}{c}0.6500^{* * *} \\
(0.047)\end{array}$ & $\begin{array}{c}0.7500^{* * *} \\
(0.052)\end{array}$ & $\begin{array}{c}0.8167^{* * *} * \\
(0.062)\end{array}$ & $\begin{array}{c}0.6500^{* * *} \\
(0.050)\end{array}$ \\
\hline Round 3 & $\begin{array}{c}1.0000^{* * *} \\
(0.096)\end{array}$ & $\begin{array}{c}0.9206^{* * *} \\
(0.137)\end{array}$ & $\begin{array}{c}0.7976^{* * *} \\
(0.215)\end{array}$ & $\begin{array}{c}1.1000^{* * *} \\
(0.097)\end{array}$ & $\begin{array}{c}0.9800 * * * \\
(0.070)\end{array}$ & $\begin{array}{c}0.9000^{* * *} \\
(0.079)\end{array}$ & $\begin{array}{c}1.1000^{* * *} \\
(0.104)\end{array}$ \\
\hline Round 4 & $\begin{array}{c}1.0685^{* * *} \\
(0.137)\end{array}$ & $\begin{array}{c}0.9603^{* * *} \\
(0.146)\end{array}$ & $\begin{array}{c}0.9524^{* * *} \\
(0.201)\end{array}$ & $\begin{array}{c}0.9250^{* * *} \\
(0.129)\end{array}$ & $\begin{array}{c}0.9500^{* * *} \\
(0.140)\end{array}$ & $\begin{array}{c}0.9667^{* *} \\
(0.234)\end{array}$ & $\begin{array}{c}0.9250^{* * *} \\
(0.139)\end{array}$ \\
\hline $\mathrm{R} 2 *$ OrderA & & $\begin{array}{c}0.3789^{* *} \\
(0.135)\end{array}$ & $\begin{array}{c}0.5905^{* *} \\
(0.234)\end{array}$ & $\begin{array}{c}0.1667^{*} \\
(0.074)\end{array}$ & & & \\
\hline R3* OrderA & & $\begin{array}{l}0.1613 \\
(0.181)\end{array}$ & $\begin{array}{c}0.4857+ \\
(0.293)\end{array}$ & $\begin{array}{c}-0.2000+ \\
(0.121)\end{array}$ & & & \\
\hline $\mathrm{R} 4 *$ OrderA & & $\begin{array}{l}0.2200 \\
(0.263)\end{array}$ & $\begin{array}{l}0.4643 \\
(0.322)\end{array}$ & $\begin{array}{l}0.0417 \\
(0.252)\end{array}$ & & & \\
\hline $\mathrm{R} 2 *$ female & & & & & $\begin{array}{c}-0.0278 \\
(0.150)\end{array}$ & $\begin{array}{l}0.2500 \\
(0.227)\end{array}$ & $\begin{array}{c}-0.1738 \\
(0.146)\end{array}$ \\
\hline $\mathrm{R} 3 *$ female & & & & & $\begin{array}{l}0.0200 \\
(0.199)\end{array}$ & $\begin{array}{l}0.3833 \\
(0.234)\end{array}$ & $\begin{array}{c}-0.3024 \\
(0.220)\end{array}$ \\
\hline $\mathrm{R} 4^{*}$ female & & & & & $\begin{array}{l}0.1958 \\
(0.174)\end{array}$ & $\begin{array}{l}0.4500 \\
(0.255)\end{array}$ & $\begin{array}{l}0.0274 \\
(0.202)\end{array}$ \\
\hline Constant & $\begin{array}{c}6.3508^{* * *} \\
(0.078)\end{array}$ & $\begin{array}{c}6.3508^{* * *} \\
(0.070) \\
\end{array}$ & $\begin{array}{c}6.4722^{* * *} \\
(0.105) \\
\end{array}$ & $\begin{array}{c}6.1800^{* * *} \\
(0.041) \\
\end{array}$ & $\begin{array}{c}6.3525^{* * *} \\
(0.082) \\
\end{array}$ & $\begin{array}{c}5.9333^{* * *} \\
(0.099) \\
\end{array}$ & $\begin{array}{c}6.7581^{* * *} \\
(0.115) \\
\end{array}$ \\
\hline Observations & 992 & 992 & 576 & 400 & 976 & 480 & 496 \\
\hline$R^{2}$ & 0.302 & 0.310 & 0.383 & 0.242 & 0.303 & 0.305 & 0.340 \\
\hline Number of players (ind. FE) & 248 & 248 & 144 & 100 & 244 & 120 & 124 \\
\hline
\end{tabular}

Table A12: Game orders used in the experiment

\begin{tabular}{|c|c|c|c|c|c|c|c|c|c|c|c|c|c|c|}
\hline \multirow{3}{*}{$\begin{array}{l}\text { Variable } \\
\text { Autarky }\end{array}$} & \multicolumn{2}{|c|}{$\begin{array}{c}\text { (1) } \\
\text { Rec order A }\end{array}$} & \multicolumn{2}{|c|}{$\begin{array}{c}(2) \\
\text { Rec order B }\end{array}$} & \multicolumn{2}{|c|}{$\begin{array}{c}(3) \\
\text { Don order A }\end{array}$} & \multicolumn{2}{|c|}{$\begin{array}{c}(4) \\
\text { Don order B }\end{array}$} & \multicolumn{6}{|c|}{$\begin{array}{c}\text { T-test } \\
\text { Difference }\end{array}$} \\
\hline & $\mathrm{N}$ & Mean/SE & $\mathrm{N}$ & Mean/SE & $\mathrm{N}$ & Mean/SE & $\mathrm{N}$ & $\mathrm{Mean} / \mathrm{SE}$ & $(1)-(2)$ & (1)-(3) & (1)-(4) & $(2)-(3)$ & $(2)-(4)$ & $(3)-(4)$ \\
\hline & 61 & $\begin{array}{c}6.836 \\
(0.157)\end{array}$ & 61 & $\begin{array}{c}5.836 \\
(0.243)\end{array}$ & 65 & $\begin{array}{c}6.646 \\
(0.168)\end{array}$ & 61 & $\begin{array}{c}6.066 \\
(0.217)\end{array}$ & $1.000^{* * * *}$ & 0.190 & $0.770^{* * * *}$ & $-0.810^{* * * *}$ & -0.230 & $0.581^{* *}$ \\
\hline Non-Local public good & 61 & $\begin{array}{c}7.885 \\
(0.174)\end{array}$ & 61 & $\begin{array}{c}7.082 \\
(0.236)\end{array}$ & 65 & $\begin{array}{c}7.523 \\
(0.180)\end{array}$ & 61 & $\begin{array}{c}7.180 \\
(0.251)\end{array}$ & $0.803^{* * *}$ & 0.362 & $0.705^{* *}$ & -0.441 & -0.098 & 0.343 \\
\hline One to One & 61 & $\begin{array}{c}7.492 \\
(0.174)\end{array}$ & 61 & $\begin{array}{c}6.984 \\
(0.227)\end{array}$ & 65 & $\begin{array}{c}7.108 \\
(0.191)\end{array}$ & 61 & $\begin{array}{c}7.082 \\
(0.264)\end{array}$ & $0.508^{*}$ & 0.384 & 0.410 & -0.124 & -0.098 & 0.026 \\
\hline Local public good & 61 & $\begin{array}{c}7.951 \\
(0.166)\end{array}$ & 61 & $\begin{array}{c}6.721 \\
(0.254)\end{array}$ & 65 & $\begin{array}{r}7.385 \\
(0.192)\end{array}$ & 61 & $\begin{array}{c}7.049 \\
(0.249)\end{array}$ & $1.230^{* * *}$ & $0.566^{* *}$ & $0.902^{* * *}$ & $-0.663^{* *}$ & -0.328 & 0.335 \\
\hline $\begin{array}{l}\text { F-test of joint significan } \\
\text { F-test, number of obser }\end{array}$ & $\begin{array}{l}\text { e (F-st } \\
\text { ations }\end{array}$ & & & & & & & & $\begin{array}{c}11.351^{* * * * *} \\
122\end{array}$ & $\begin{array}{c}1.770 \\
126\end{array}$ & $\begin{array}{c}6.312^{* * * *} \\
122\end{array}$ & $\begin{array}{l}6.655^{* * * *} \\
126\end{array}$ & $\begin{array}{c}0.597 \\
122\end{array}$ & $\begin{array}{c}3.374^{* *} \\
126\end{array}$ \\
\hline
\end{tabular}

Table A13: Average effort levels per game 


\section{Appendix B: Experimental Protocol}

Script of the session

\begin{tabular}{|l|l|}
\hline \multicolumn{2}{|c|}{ 1. Presentation : joint group, common room. } \\
\hline 2 A : RECIPIENTS_ Laboratory & 2 B : HELPERS_Common room \\
\hline 3 A : RECIPIENTS_Common room: Questionnaire & 3 B : HELPERS_Laboratory \\
\hline 4 A : RECIPIENTS_Common room: Payments & 4 B : HELPERS_Laboratory: Questionnaire, payments. \\
\hline \multicolumn{2}{|c|}{ 5. Snack and farewell: joint group, common room } \\
\hline
\end{tabular}

Note: Upon arrival all the participants will be together, the activity will be presented and cards will be randomly distributed in order to assign the participants to the group of DONORS or RECIPIENTS. The cards will be numbered from 1 to 40 and at the end of the presentation participants with the full red dot will be asked to stay in the room while the participants with half red dot (odd) will be ask to go to the room fitted as laboratory.

Good morning / Good afternoon. We are researchers from the Banco de México and from Toulouse School of Economics. First of all, we will like to thank you for voluntarily assisting to this meeting.

Today we will do a decision-making activity and you will be asked to answer a questionnaire. We will explain you each step of every activity, and we will make all the pauses needed to answer all the questions you may have.

\section{RULES OF THE ACTIVITY}

Before we start, we want to explain three very important points:

1. Anonymity : All the decisions and all the answers will be completely anonymous. We will never tell no one what you did or answered. Each one of you has an identifying number and from this moment on all of what you do will be registered to that number, never with your name; therefore, there will be no connection between your name and the decisions you take.

2. Privacy: All participants will avoid to turn around and watch the movements of other participants in the activity or to speak to them.

3. Yours decisions are worth money: During this morning/afternoon, you will have to make decisions and you will win points. Be a little patient, we will explain later how you can win points. The important thing for you to know is that each point is worth fifty cents.

Let me remind you the rules of the activity:

1. Anonymity

2. Privacy

3. 1 point $=50$ cents 
Your participation is completely voluntary. You may leave the room at any time you want. This activity will last around two hours. Unfortunately, if you decide to leave the activity before the end of the session we won't be able to calculate your points and, therefore, your payment.

The payments will be made at the end of the session after you answer a questionnaire.

Are there any questions?

Very well, let's begin then. We now please ask to the participants with half red dot filled (odd) to go into the room. The participants with the full red dot (even) will remain in this room.

When entering the room we ask the participants with half red dot (odd) to search for the table with your number and to take a seat.

Please do it quietly.

Take the participants to the room. Help the participants to find their table.

\section{Room: AbILITy test AND TASK PRESENTAtion}

Thanks again for your participation. Please sit down in the table with your number so that we can start with the activity. Let me remind you that the rules of the activity are ANONYMITY, PRIVACY, and that the decisions are worth MONEY (1 point $=50$ cents).

\{Write on the blackboard the three rules\}

Let me remind you that your participation is completely voluntary. You can leave the room anytime you want. The activity will last around two hours. Unfortunately if you decide to leave the activity before the end of the session we won't be able to calculate your points, and therefore, your payment.

Very important: The points you will gain depend only of your own decisions, and not on the decision made by others. From this moment on, you are on your own.

You have on your table:

1. Your number.

2. A book with the magazine that you chose.

3. A pen, later I will explain to what for, don't worry you don't need to know how to write for this activities.

Do you have all these items on the table? 


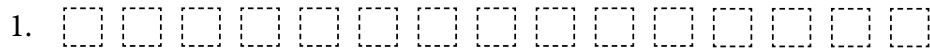

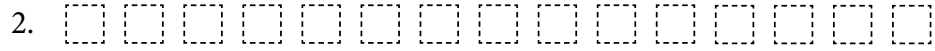

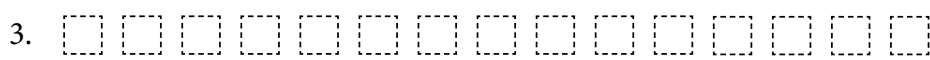

Figure B1: Form given to the participants to perform the Ability test

\section{A. Ability test}

Before we start this activity, we are going to propose you a first way to gain points. During one minute and a half you will be asked to draw crosses in the boxes that are in your sheet as I am doing. Look carefully, you have to start with the first line or row and then move to the second one, then with the third one, and so on. Notice also that crosses must be drawn properly, if you draw a cross like the one I am showing you, it does not count! For each line or row that you complete with crosses I will give you one point. Remember, each point at the end of the session will be converted to fifty cents.

Are there any questions?

If there are no questions, we will start counting the time for you to draw crosses. During this time you may take a look at the magazines if you wish to do so. Time will start running when I blow my whistle and it will stop when I blow it for the second time. Please, when I blow the whistle for the second time stop drawing crosses or stop taking a look at the magazines. Is it clear?

Blow the whistle - 1.5 min- blow the whistle. Stop please..

1. Take the form of the ability test (Figure B1). 2. Mark the form with the number of crosses completed in each table.

\section{B. Effort activities}

Thank you. We will now propose you four activities to win points.

My colleagues will hand you an instruction template (Figure B2) and four cards with different colors. Please don't touch the materials until we say so.

1. Hand out the instruction template and the cards.

Let's look the instruction template that my colleague handed you. 


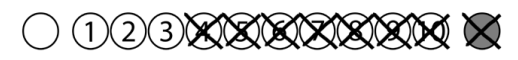

1.

2.

3. $\square \square \square$

4.

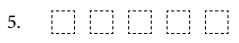

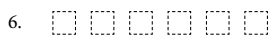

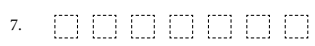

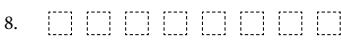

9. 00000000

10. 000000000
(1)(2)(3)(4)(5)(7)(8) $\times$

1.

2. $\square \square$

3. 미

4. ㅁㅁ

5. ㅁำ

6. 뭄

7. ㅁㅁㅁㅁำ

8. ㅁㅁㅁㅁ

9. 뭄ำ

10. 0101001010

Figure B2: Booklet to explain conversion of lines completed into balls. Booklet had 10 pages (here page 3 and 9 as examples).

We will propose you a way to win points by drawing crosses.

Here I have a raffle box, do you see this raffle box that I have on the table (point at it)? In this raffle box there are balls numbered from 1 to 10. At the end of the session, I will make a draw and take out just one ball. The number of that ball we will be used to calculate your payments according to whether that ball is one of those you have acquired or not. Soon I will explain you how to get the balls, the important thing right now is that you know that there are ten balls in the raffle box.

Are there any questions?

So, how do we get the balls? You have on the table a sheet with boxes (Figure B3)

Does anyone don't have the sheet? Well, as you can see in each row or line there is a circle with a number. Each circle represents one ball of the raffle box. Can you see the circles in your sheets? They are those that are on this side of the sheet (point out the left side of the white sheet).

For you to get one ball or several balls for the raffle box, you have to draw a cross on each of the boxes that appear in the line or row. You are not allowed to start on one line of this side and then to begin the another line from the other side. You have always to begin with the first line of boxes, then move to the second one, then the third one, then the forth one and so on until you reach the last line which corresponds to the number 10 .

For example, if you complete the first line drawing crosses in the boxes, you will get the ball number one for the raffle box. 


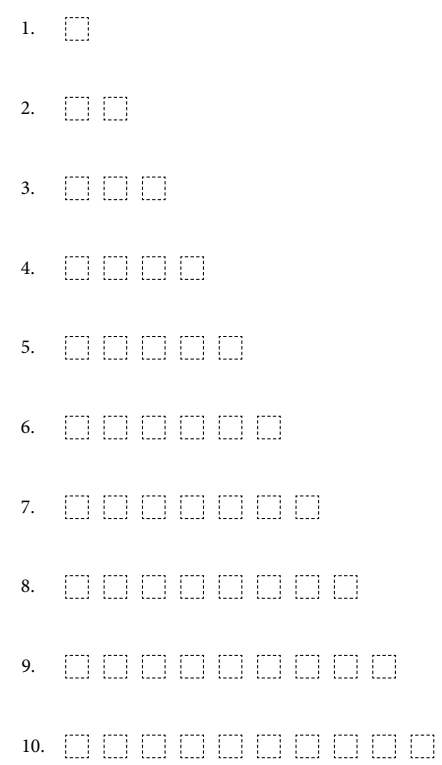

Figure B3: Form given to the participants to perform the Ability test

You have on your table a template with boxes like the one I have here.

At the end of the session, we will make a draw with the raffle box. From the raffle box we will take out only one ball. With that ball number we will calculate your payments. But be patient, we will explain later how the payments work.

What happens from now on? We will explain in detail each one of the activities: the pink, the green, the blue and the yellow one. I will now put the cards of all four colors in this bag. At the end of the session, we will choose a helper to randomly pick one card from the bag. The color of the card drawn will represent the color of the activity that will be used to determine your payments.

Are there any question so far? Very well, let's begin then.

I will briefly summarize what I just said: you will draw crosses in the boxes, by doing so you will acquire balls for the draw that will be held at the end of the session. Keep in mind that only one of the four color cards will be chosen by the helper and that this card together with the number in the ball drawn is what we will use to calculate your payments.

Any question so far? 


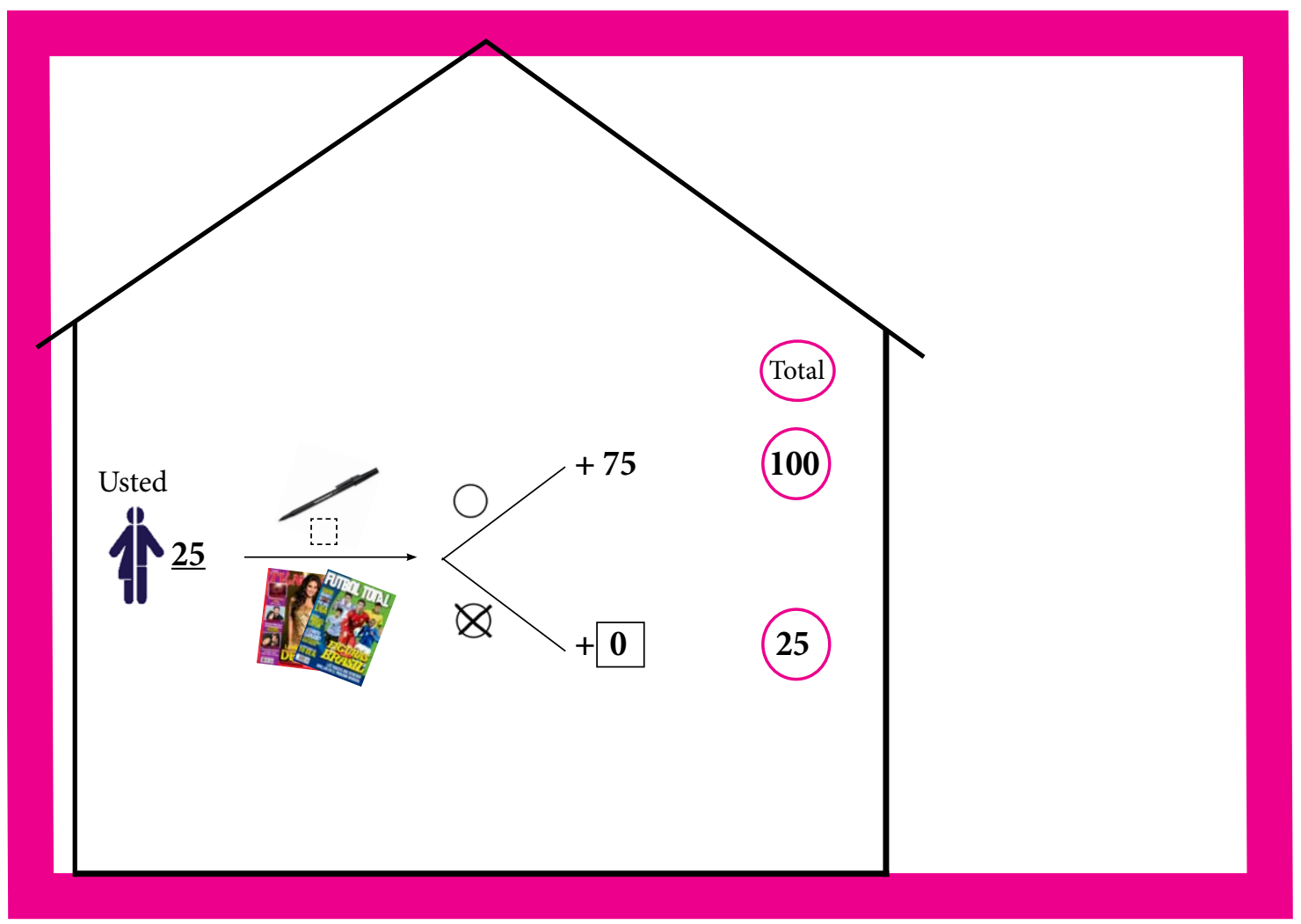

Figure B4: Form for Recipient Autarky Game

\section{Room: Group A (RECIPIENTS)}

\section{A. Recipients autarky}

Let's begin then with our first activity. My colleague will hand out a pink template.

1. Hand out the pink templates.

Does anyone don't have the pink template yet? (Figure B4)

In the pink template we can see that you already have 25 points. What happens if you draw a cross on each of the boxes? You will complete levels and therefore acquire balls for the raffle draw, just like we saw in the white template. If after the raffle draw one of the balls that you acquire by drawing crosses is drawn, as you can see in the upper line, you will get 75 additional points to the 25 points you already have, that is, 100 in total. If the ball drawn is not one of the balls you acquired by completing levels drawing crosses, as you can see in the bottom line, you will get zero extra points, keeping the original 25 points.

Is it clear?

In the pink card, we will write down the levels you completed by drawing crosses in the boxes of the template. Remember, the pink card is in this bag, and at the end of the activity it may or not be chosen by the 
helper. Are we clear?

If there are no questions, we will start counting the time for drawing crosses in the boxes. During this time you may look at the newspaper if you wish to do so. Time starts running when I blow the whistle and it will end when I blow the whistle for the second time. Please, when I blow the whistle for the second time stop drawing crosses or looking at the newspaper. Is it clear?

blow the whistle - 1min- blow the whistle. Please stop.

My colleague will pass by the tables and write down in the pink card the levels you have completed, he will also collect the templates with the boxes and give you a new template.

Please remain silent.

1. Collect the pink templates. 2. Write down in the pink template the number of levels completed in each table. 3. Give a new template with boxes.

\section{B. Recipients transfer from one individual}

Excellent, now we will move to the second activity. My colleague will hand out a green template.

1. Hand out the green templates (Figure B5).

In the green template we can see you already have 25 points.

What happens if you draw a cross on each of the boxes? You will complete levels and therefore acquire balls for the raffle draw, just like we saw in the white template. If after the raffle draw one of the balls that you acquire by drawing crosses is drawn, as you can see in the upper line, you will get 75 additional points to the 25 points you already have, that is, 100 in total. If the ball drawn is not one of the balls you acquired by completing levels drawing crosses, as you can see in the bottom line, you will get the 25 points you already had plus 75 points of one of the participants of the other group, that at the beginning when they arrived, had a full red dot (even).

Do you remember the participants that were assigned to the other room? You have been randomly matched with a participant of the other group. The person with whom you have been matched has received 175 points. If none of the balls you have acquired is drawn, that person will have to give you 75 points of the 175 he received. Keeping the anonymity, neither you nor the person you have been matched with will know to whom you have been matched.

Is it clear?

In the green card, we will write down the levels you completed by drawing crosses in the boxes of the template. Remember, the green card is in this bag, and at the end of the activity it may or not be chosen by the helper. Are we clear? 


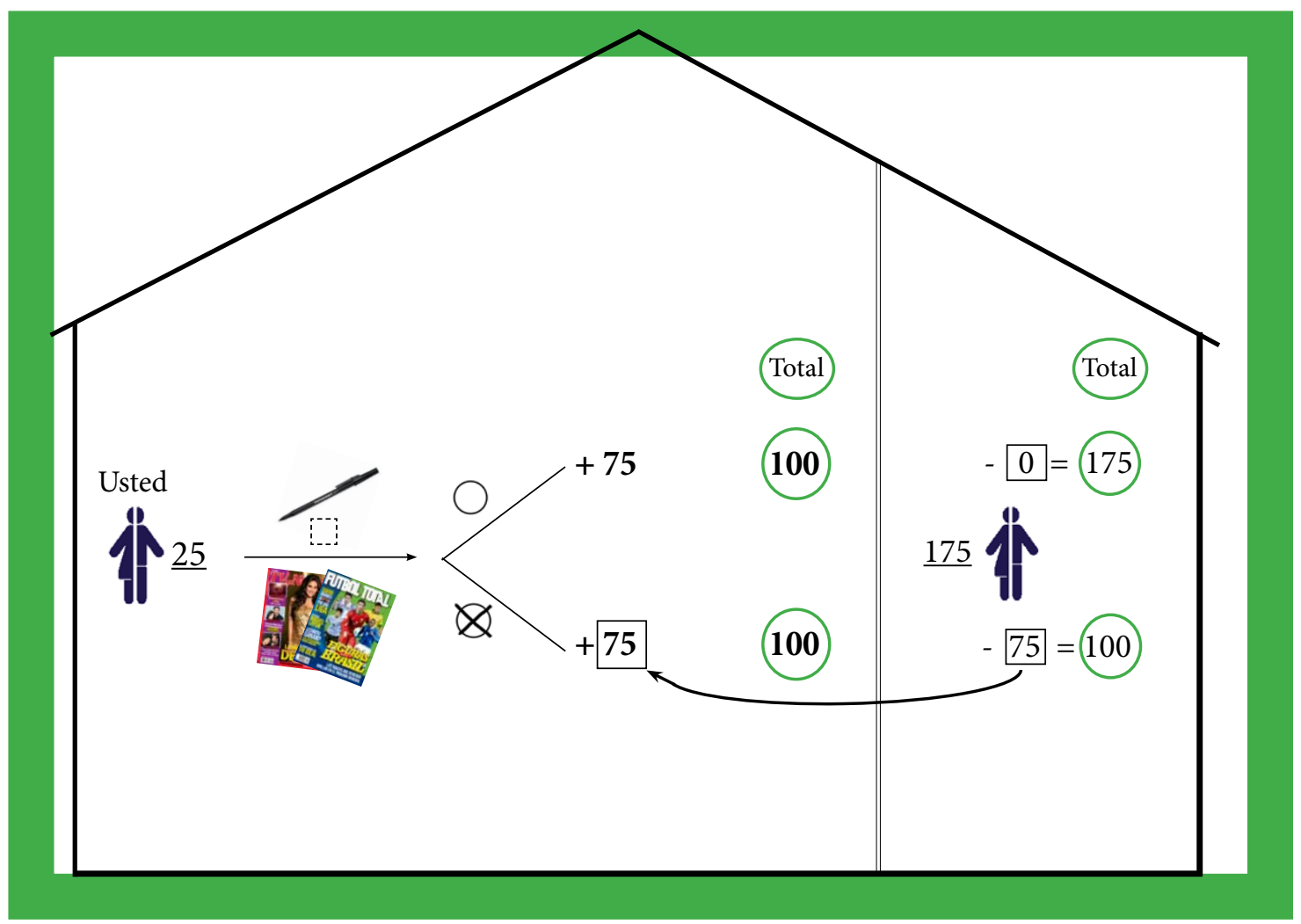

Figure B5: Form for Recipient One to One Game

If there are no questions, we will start counting the time for drawing crosses in the boxes. During this time you may look at the newspaper if you wish to do so. Time starts running when I blow the whistle and it will end when I blow the whistle for the second time. Please, when I blow the whistle for the second time stop drawing crosses or looking at the newspaper. Is it clear?

blow the whistle - 1min- blow the whistle. Please stop. My colleagues will write down how many levels you have completed.

My colleague will pass by the tables and write down in the green card the levels you have completed, he will also collect the templates with the boxes and give you a new template.

Please remain silent.

1. Collect the green templates. 2. Write down in the number of levels completed in each table. 3. Give a new template with boxes.

\section{C. Recipients full: transfer from local public good (LPG)}

Thank you. We will know move to the third activity. Let me before remind you the rules of the game: anonymous, private, and for each point you get we will give you 50 cents. 


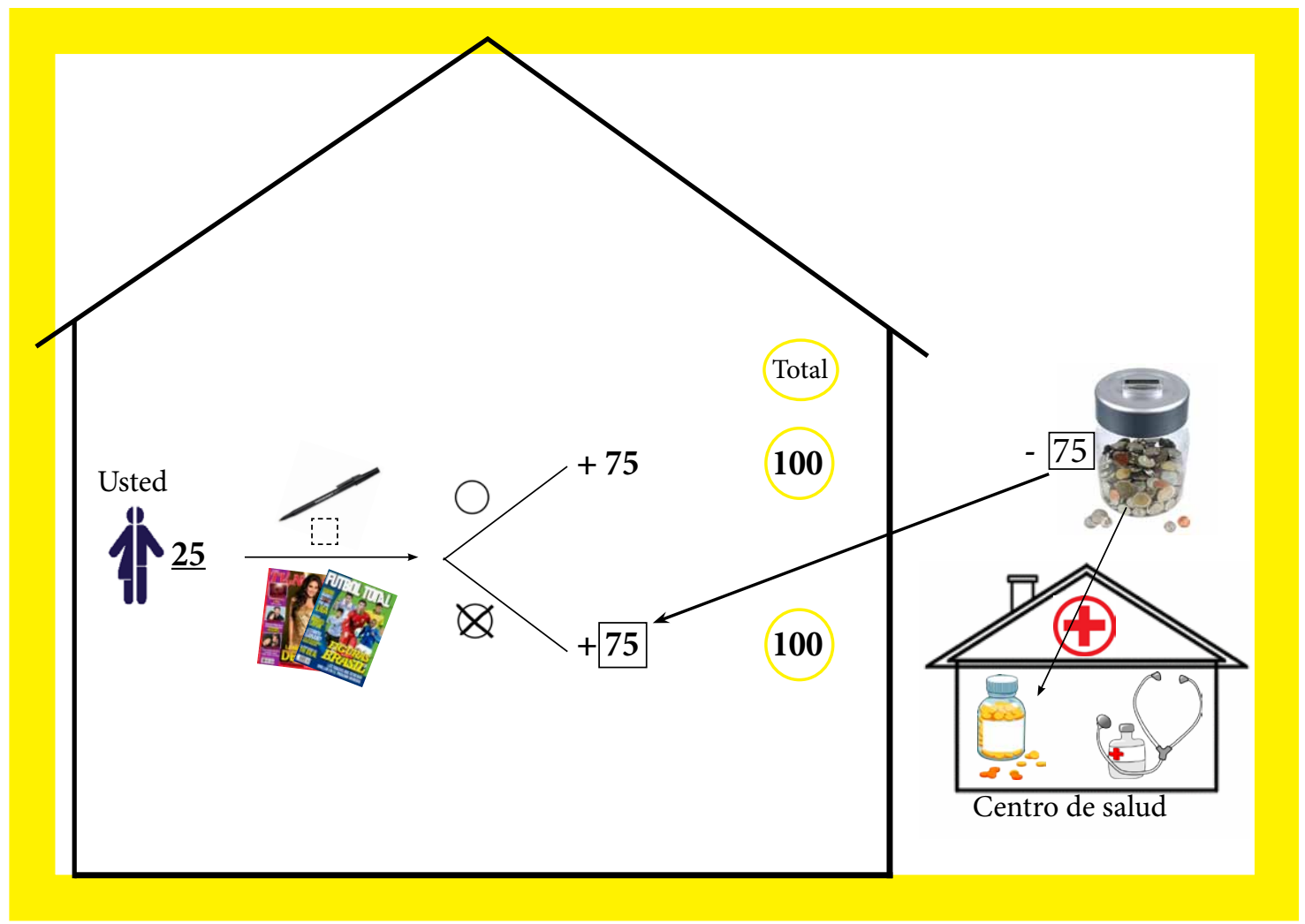

Figure B6: Form for Recipient LPG game

I remind you as well that at the end of all activities the color that will be chosen at random from a helper will be used to determine your payments.

We will now present you the third activity. My colleague will hand out the yellow templates.

1. Hand out the yellow templates (Figure B6).

Does anyone don't have the yellow template?

In the yellow template we can see that you already have 25 points. What happens if you draw a cross on each of the boxes? You will complete levels and therefore acquire balls for the raffle draw, just like we saw in the white template. If after the raffle draw one of the balls that you acquire by drawing crosses is drawn, as you can see in the upper line, you will get 75 additional points to the 25 points you already had, that is, 100 in total. But, what happens if the ball drawn is not one of the balls you acquired?

Please read carefully the bottom line of the yellow template. We have here a tin of $175 \mathrm{~N}$ points.

\{Write on the blackboard the multiplication of $175^{*} \mathrm{~N}$ equal to ... with a design of a tin $\}$

In this activity, if the ball drawn is not one of those you have acquired, you will get 75 points that we will 
take out from this tin. The points that remain in the tin after the draw will be given to one Health Center of your locality.

Is it clear?

In the yellow card, we will write down the levels you completed by drawing crosses in the boxes of the template. Remember, the yellow card is in this bag, and at the end of the activity it may or not be chosen by the helper. Are we clear?

If there are no questions, we will start counting the time for drawing crosses in the boxes. During this time you may look at the newspaper if you wish to do so. Time starts running when I blow the whistle and it will end when I blow the whistle for the second time. Please, when I blow the whistle for the second time stop drawing crosses or looking at the newspaper. Is it clear?

blow the whistle - 1min- blow the whistle. Please stop.

Thank you. My colleague will pass now to write down in the yellow card the levels you have completed, he will also collect the templates with the boxes and give you a new template.

Remember that you must remain silent. Thank you.

1. Collect the yellow templates. 2. Write down in the number of levels completed in each table. 3. Give a new template with boxes.

\section{D. Recipients transfer from non-local public good (NLPG)}

We will now move to the forth and last activity. My colleague will hand out the blue template.

1. Hand out the blue templates (Figure B7).

Does anyone don't have the blue template?

In the blue template we can see that you already have 25 points. What happens if you draw a cross on each of the boxes? You will complete levels and therefore acquire balls for the raffle draw, just like we saw in the white template. If after the raffle draw one of the balls that you acquire by drawing crosses is drawn, as you can see in the upper line, you will get 75 additional points to the 25 points you already had. But, what happens if the ball drawn is not one of the balls you acquired?

Please read carefully the bottom line of the blue template. We have here a tin of $175 \mathrm{~N}$ points.

\{Write on the blackboard the multiplication of $175^{*} \mathrm{~N}$ equal to ... with the design of a tin $\}$ 


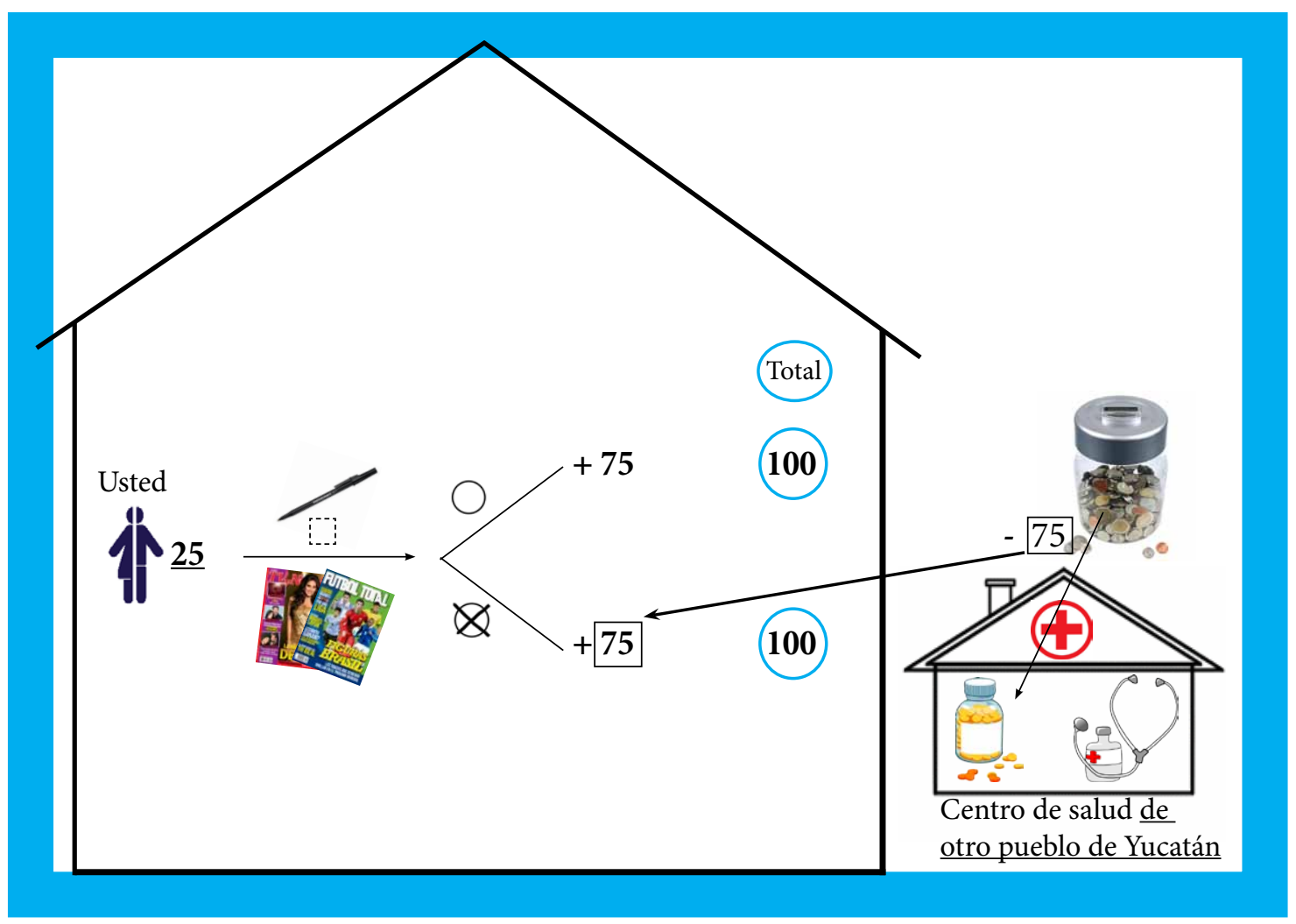

Figure B7: Form for Recipient NLPG Game

In this activity, if the ball drawn is not one of those you have acquired, you will get 75 points that we will take out from this tin. The points that remain in the tin after the draw will be given to the Health Center of an other locality (name of matched locality given).

Is it clear?

In the blue card, we will write down the levels you completed by drawing crosses in the boxes of the template. Remember, the blue card is in this bag, and at the end of the activity it may or not be chosen by the helper. Are we clear?

If there are no questions, we will start counting the time for drawing crosses in the boxes. During this time you may look at the newspaper if you wish to do so. Time starts running when I blow the whistle and it will end when I blow the whistle for the second time. Please, when I blow the whistle for the second time stop drawing crosses or looking at the newspaper. Is it clear?

blow the whistle - 1min- blow the whistle. Please stop. My colleagues will write down how many levels you have completed.

Thank you. My colleague will pass now to write down in the yellow card the levels you have completed, he will also collect the templates with the boxes. 
Remember that you must remain silent. Thank you.

1. Collect the blue templates. 2. Write down in the number of levels completed in each table. 3. Give a new template with boxes.

\section{E. Second ability test}

Thanks very much for your participation. We will give you a last chance to accumulate points.

We will propose to you that for one minute you draw crosses in the boxes (Figure B1). For each level completed, we will give you one point. Each point in the end will be converted into 50 cents.

Any questions?

If there are no questions, we will start counting the time for drawing crosses in the boxes. During this time you may look at the newspaper if you wish to do so. Time starts running when I blow the whistle and it will end when I blow the whistle for the second time. Please, when I blow the whistle for the second time stop drawing crosses or looking at the newspaper. Is it clear?

blow the whistle - 1min- blow the whistle. Please stop. My colleagues will write down how many levels you have completed.

Collect the templates, write down the levels completed.

\section{F. Questionnaire}

Thank you for your participation. My colleague will now hand out an answer sheet with one question. Let me read it out loud.

1. Hand out the questionnaires. 2. Hand out once more the green template.

As you were told during the green activity, you were randomly matched with a participant of the other room. That participant has not received any information about the levels you have drawn.

\begin{tabular}{|l|c|c|}
\hline Question & Yes & No \\
\hline \hline $\begin{array}{l}\text { If we were to give you the possibility to tell to the other participant } \\
\text { how many levels you draw during the green activity, will you accept? }\end{array}$ & $\square$ & \\
\hline
\end{tabular}

Please, mark yes or no in the answer sheet, according to what you think best. 
Thank you, my colleagues will now collect the answer sheets and the 4 cards of the previous activities.

Collect the answer sheets and cards.

We will keep all the cards and the questionnaires in this transparent box. This box will be closed here with me at all times. After the other participants that are in the other room have passed through here, we will make the draw with the raffle draw, we will choose the helper and calculate your payments.

We ask you now to go to the room that my colleague is going to show you.

Take the participants to the room.

\section{Room: Group B (DONORS)}

\section{A. Donors autarky}

Let's begin then with our first activity. My colleague will hand out a pink template.

1. Hand out the pink templates (Figure B8).

Does anyone don't have the pink template?

In the pink template we can see that you already have 100 points. What happens if you draw a cross on each of the boxes? You will complete levels and therefore acquire balls for the raffle draw, just like we saw in the white template. If after the raffle draw the ball drawn does not correspond to one of the levels that you have completed, as you can see in the bottom line, you keep the 100 points you already had. If the ball drawn corresponds to one of the levels you have completed, as you can see in the upper line, you will get 75 extra points, keeping the original 100 points, that is, a total of 175 points.

Is it clear?

In the pink card, we will write down the levels you completed by drawing crosses in the boxes of the template. Remember, the pink card is in this bag, and at the end of the activity it may or not be chosen by the helper. Are we clear?

If there are no questions, we will start counting the time for drawing crosses in the boxes. During this time you may look at the newspaper if you wish to do so. Time starts running when I blow the whistle and it will end when I blow the whistle for the second time. Please, when I blow the whistle for the second time stop drawing crosses or looking at the newspaper. Is it clear?

blow the whistle - 1min- blow the whistle. Please stop. My colleagues will write down how many levels you have completed.

My colleague will pass by the tables and write down in the pink card the levels you have completed, he will 


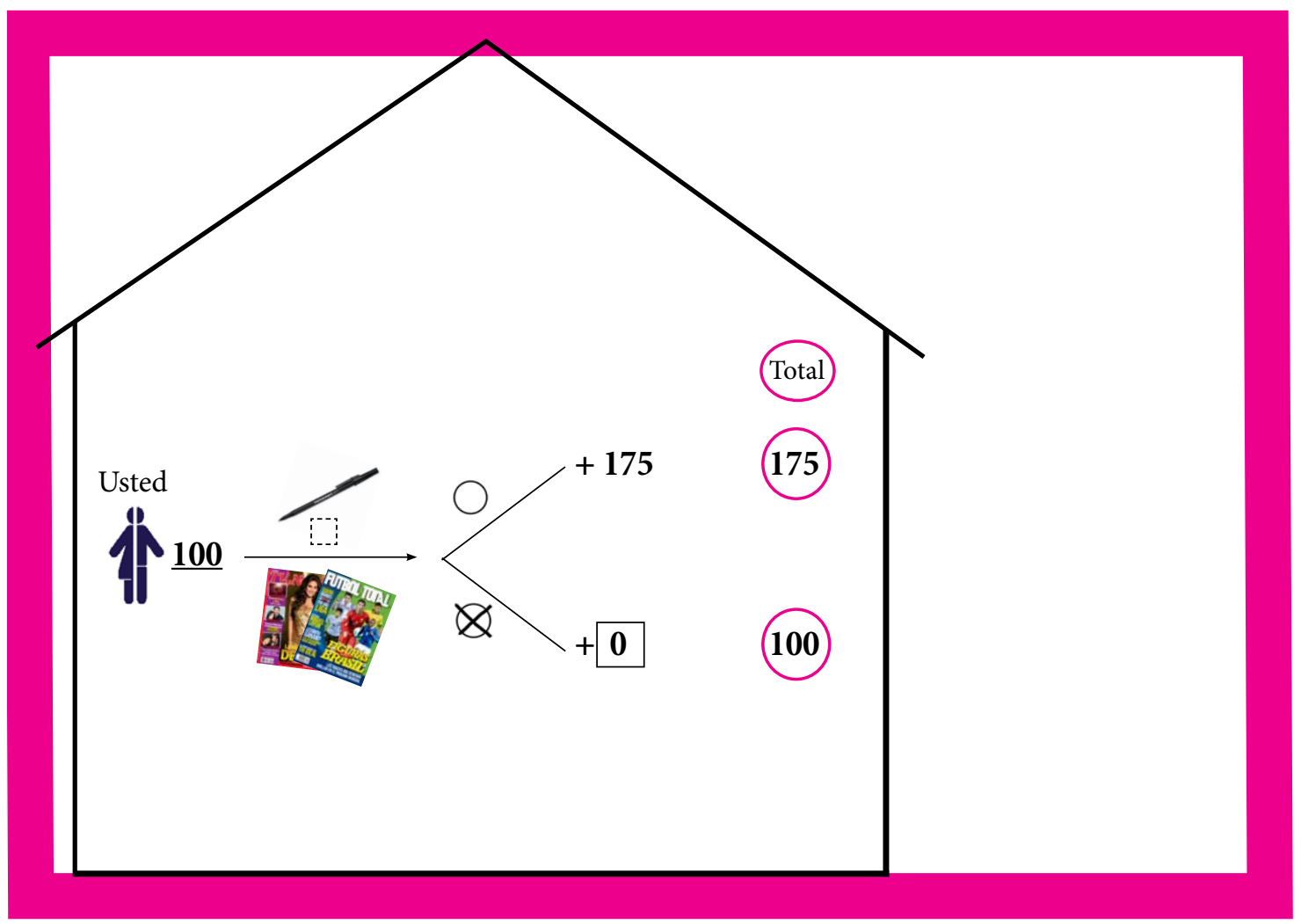

Figure B8: Form for Donor Autarky Game

also collect the templates with the boxes and give you a new template.

Please remain silent.

1. Collect the pink templates. 2. Write down in the number of levels completed in each table. 3. Give a new template with boxes.

\section{B. Donors full: transfer to one individual}

Excellent, now we will move to the second activity. My colleague will hand out a green template.

1. Hand out the green templates (Figure B9).

Does anyone don't have the green templates?

In the green template we can see you already have 100 points.

What happens if you draw a cross on each of the boxes? You will complete levels and therefore acquire balls for the raffle draw, just like we saw in the white template. As you can see in the bottom line, if after the raffle draw the ball drawn does not correspond to the levels you have completed, you will keep the 100 in total. If after the raffle draw the ball drawn corresponds to one of the levels you have completed, as you may see in 


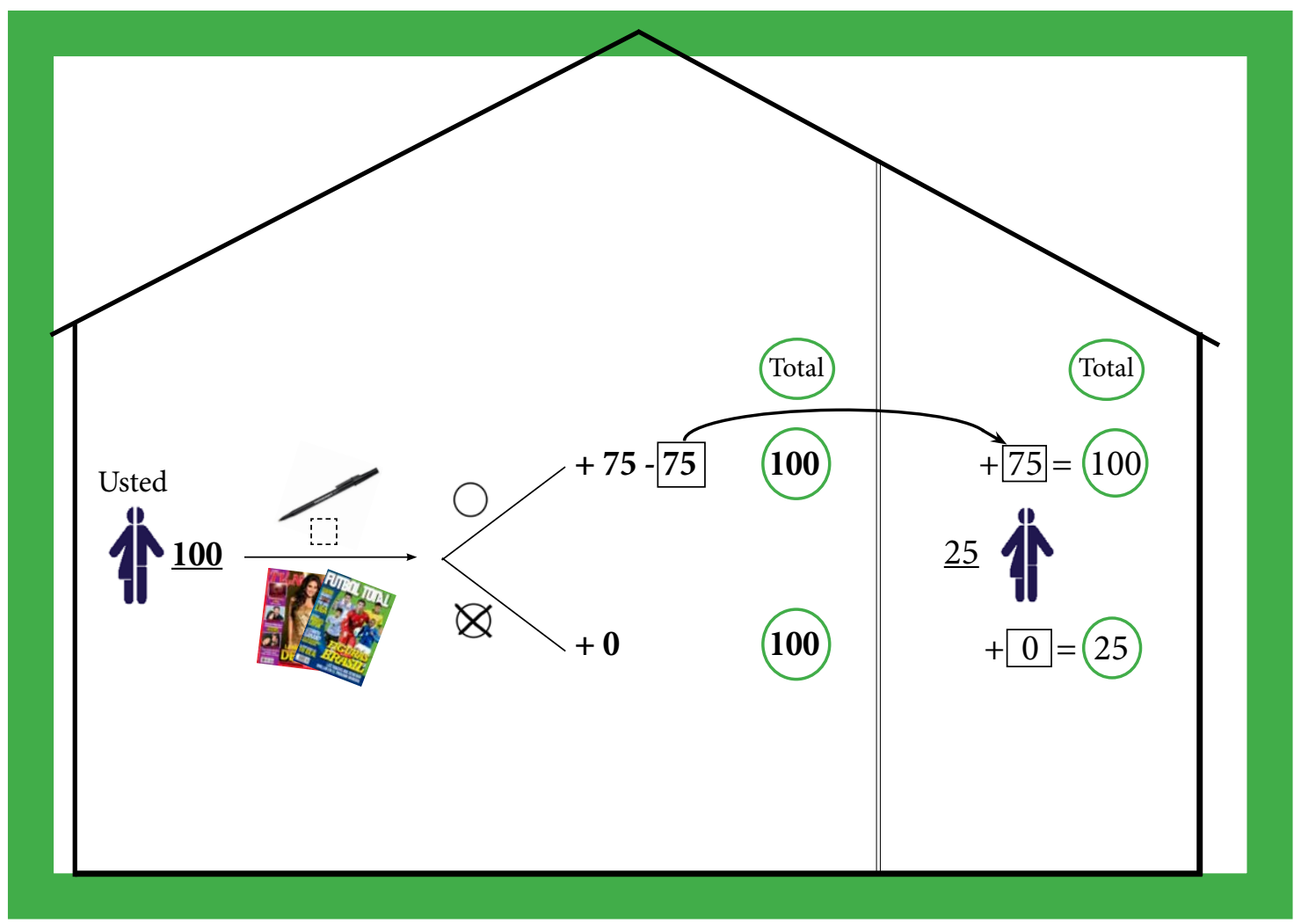

Figure B9: Form for Donor One to One Game

the upper line, you will get 75 additional extra points to the 100 points you already had. However, of those 75 points you have acquired, you will give 75 points to one of the participants that were assigned to the other room, so that you will end up with 100 points in total.

Do you remember the participants that were assigned to the other room? Each one of you has been randomly matched with a participant of the other group. The person with whom you have been matched has received 25 points. Keeping the anonymity of the game, neither you nor the person you have been matched with will know to whom you have been matched.

Is it clear?

In the green card, we will write down the levels you completed by drawing crosses in the boxes of the template. Remember, the green card is in this bag, and at the end of all the activities it may or not be chosen by the helper. Are we clear?

If there are no questions, we will start counting the time for drawing crosses in the boxes. During this time you may look at the newspaper if you wish to do so. Time starts running when I blow the whistle and it will end when I blow the whistle for the second time. Please, when I blow the whistle for the second time stop drawing crosses or looking at the newspaper. Is it clear?

blow the whistle - 1min- blow the whistle. Please stop. My colleagues will write down how many levels you 
have completed.

My colleague will pass by the tables and write down in the green card the levels you have completed, he will also collect the templates with the boxes and give you a new template.

Please remain silent.

1. Collect the green templates. 2. Write down in the green card the number of levels completed in each table. 3. Give a new template with boxes.

\section{C. Donors transfer to local public good ( $L P G)$}

Thank you. We will know move to the third activity. Let me before remind you the rules of the game: anonymous, private, and for each point you get we will give you 50 cents.

I remind you as well that at the end of all activities the color that will be chosen at random from a helper will be used to determine your payments.

We will now present you the third activity. My colleague will hand out the yellow templates.

1. Hand out the yellow templates (Figure B10).

Does anyone don't have the yellow template?

In the yellow template we can see that you already have 100 points. What happens if you draw a cross on each of the boxes? You will complete levels and therefore acquire balls for the raffle draw, just like we saw in the white template. If after the raffle draw the ball drawn is not one of those you have acquired, as you can see in the bottom line, you will keep the original 100 points. If after the draw with the raffle draw one of the balls you have acquired is drawn, as you can see in the upper line, you will get 75 additional points to the 100 points you already had. However, of the 75 points you have acquired, we will take those 75 points to put them in the tin we see here, so that you end up with 100 points in total. In this tin we already have $25 \mathrm{~N}$ points.

\{Write on the blackboard the multiplication of $25^{*} \mathrm{~N}$ equal to ... with a design of a tin $\}$

The points collected through out this activity will go to this tin that we will give to the Health Center of your locality.

Is it clear?

In the yellow card,we will write down the levels you completed by drawing crosses in the boxes of the template. Remember, the yellow card is in this bag, and at the end of all the activities it may or not be chosen by the helper. Are we clear? 


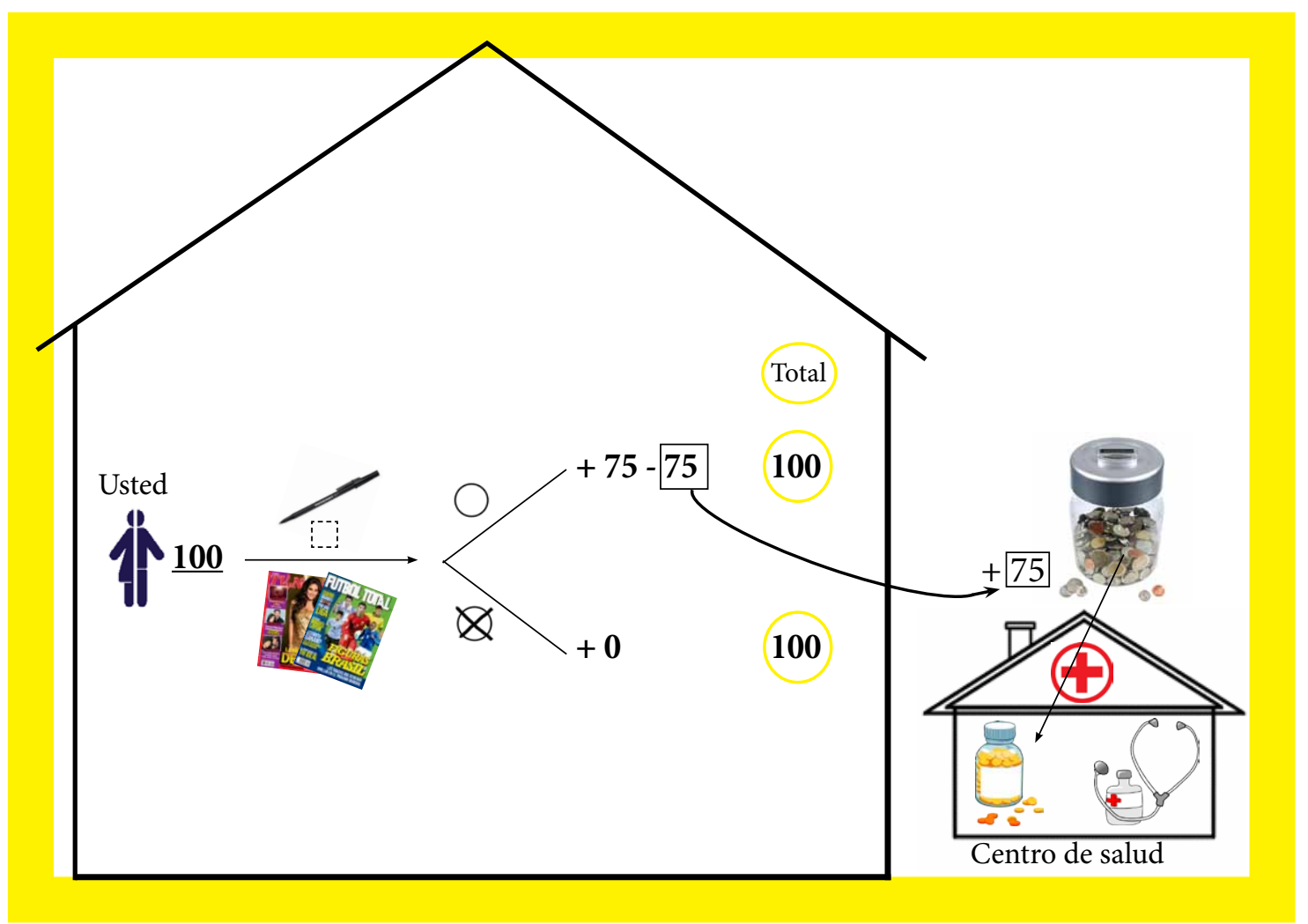

Figure B10: Form for Donor LPG game

If there are no questions, we will start counting the time for drawing crosses in the boxes. During this time you may look at the newspaper if you wish to do so. Time starts running when I blow the whistle and it will end when I blow the whistle for the second time. Please, when I blow the whistle for the second time stop drawing crosses or looking at the newspaper. Is it clear?

blow the whistle - 1min- blow the whistle. Please stop. My colleagues will write down how many levels you have completed.

Thank you. My colleague will pass now to write down in the yellow card the levels you have completed, he will also collect the templates with the boxes and give you a new template..

Remember that you must remain silent. Thank you.

1. Collect the yellow templates. 2. Write down in the blue card the number of levels completed in each table. 3. Give a new template with boxes.

\section{D. Donors transfer to non-local public good (NLPG)}

We will now move to the forth and last activity. My colleague will hand out the blue template. 


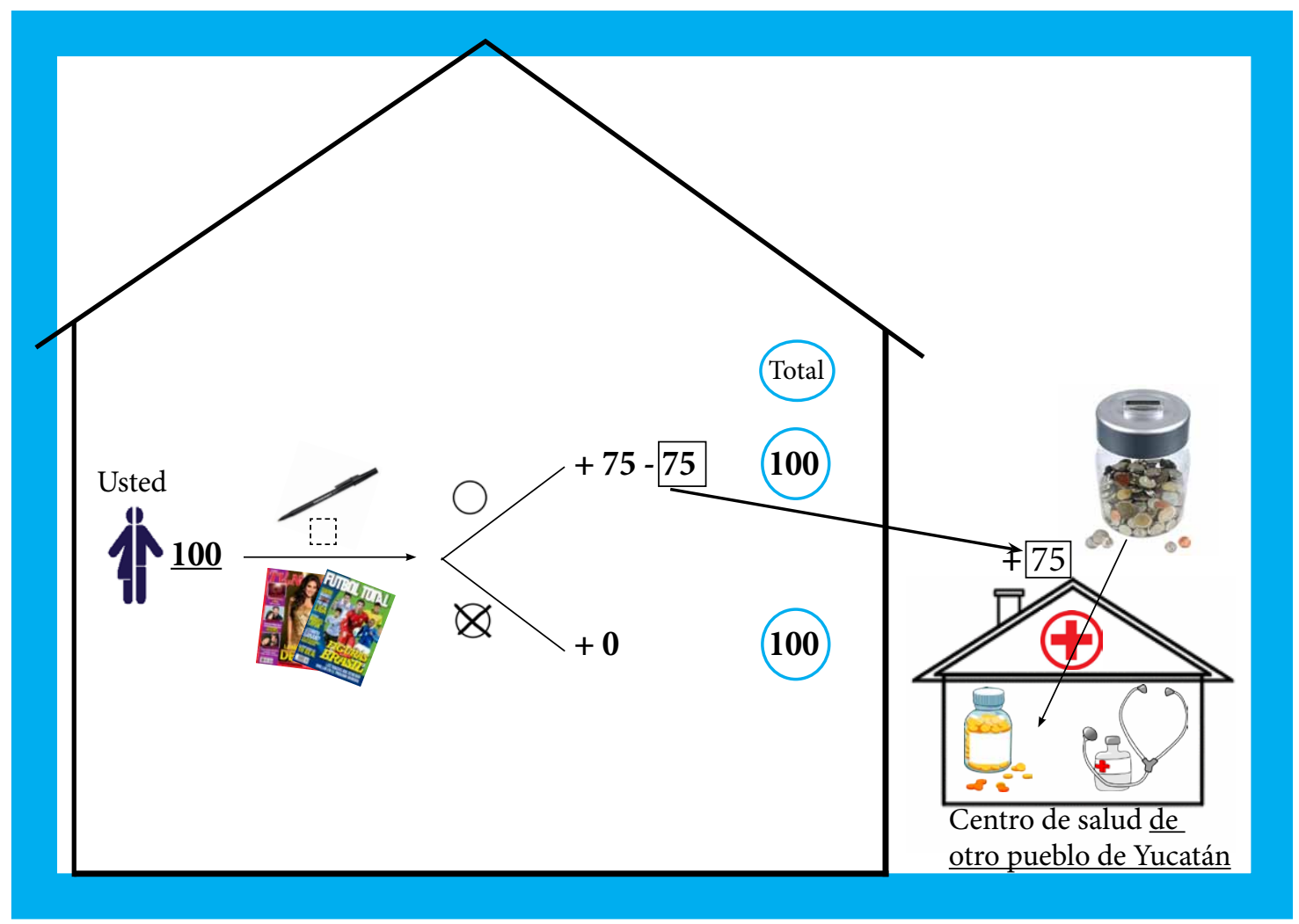

Figure B11: Form for Donor NLPG Game

\section{Hand out the blue templates (Figure B11).}

Does anyone don't have the blue template?

In the blue template we can see that you already have 100 points. What happens if you draw a cross on each of the boxes? You will complete levels and therefore acquire balls for the raffle draw, just like we saw in the white template. If after the raffle draw the ball drawn is not one of the balls you acquired, as you may see in the bottom line, you keep the 100 points. If after the draw with the raffle draw, one of the balls that you acquire is drawn, as you can see in the upper line, you will get 75 additional points to the 100 points you already had. However, of the 75 points you have acquired, we will take 75 points to put them in the tin we see here, so that you end up with 100 points in total. In this tin we already have $25 \mathrm{~N}$ points.

\{Write on the blackboard the multiplication of $25 * \mathrm{~N}$ equal to ... with the design of a tin $\}$

The points that remain in the tin after the draw will be given to the Health Center of an other locality (locality announced).

In the blue card, we will write down the levels you completed by drawing crosses in the boxes of the template. Remember, the blue card is in this bag, and at the end of all the activities it may or not be chosen by the helper. Are we clear? 
If there are no questions, we will start counting the time for drawing crosses in the boxes. During this time you may look at the newspaper if you wish to do so. Time starts running when I blow the whistle and it will

end when I blow the whistle for the second time. Please, when I blow the whistle for the second time stop drawing crosses or looking at the newspaper. Is it clear?

blow the whistle - 1min- blow the whistle. Please stop. My colleagues will write down how many levels you have completed.

Thank you. My colleague will pass now to write down in the blue card the levels you have completed, he will also collect the templates with the boxes.

Remember that you must remain silent. Thank you.

1. Collect the yellow templates. 2. Write down in the card the number of levels completed in each table. 3 . Give a new template with boxes.

\section{E. Second Ability Test}

Thanks very much for your participation. We will give you a last chance to accumulate points.

We will propose to you that for one minute you draw crosses in the boxes. For each level completed, we will give you one point. Each point in the end will be converted into 50 cents (Figure B1).

Any questions?

If there are no questions, we will start counting the time for drawing crosses in the boxes. During this time you may look at the newspaper if you wish to do so. Time starts running when I blow the whistle and it will end when I blow the whistle for the second time. Please, when I blow the whistle for the second time stop drawing crosses or looking at the newspaper. Is it clear?

blow the whistle - 1min- blow the whistle. Please stop. My colleagues will write down how many levels you have completed.

Collect the templates, write down the levels completed.

\section{F. Questionnaire}

My colleague will now hand out an answer sheet with some questions. Let's read it together. 
1. Hand out the questionnaires. 2. Hand out once more the green template.

Allow me to make you some questions. My colleague hands out the green template once more. Remember that you were randomly matched with a participant of the other room. In the green template, we can see that you were to give 75 points of your profits to that person, in the case that one of the balls you acquired was drawn.

\begin{tabular}{|l|c|c|}
\hline Question & Yes & No \\
\hline \hline Would you like to give him less that 75 points? & & \\
\hline If yes, How much less? & \multicolumn{2}{|l|}{} \\
\hline $\begin{array}{l}\text { Will you change your mind if that person had the chance } \\
\text { to accumulate points by drawing crosses? }\end{array}$ & & \\
\hline
\end{tabular}

Please, choose the answer according to what you think best.

Thank you, my colleagues will now collect the materials and the answer sheets.

We will keep all the cards and questionnaires in this transparent box. This box will be closed here with me at all times. We will now make the draw with the raffle draw, we will choose the helper and calculate your payments.

We ask you now to go to the room that my colleague is going to show you. We ask you to remain silent and not to talk to the other participants. 